Louisiana State University

LSU Digital Commons

1987

\title{
Acceptability and Effectiveness of Group Contingencies for Improving Spelling Achievement.
}

Timothy Lawrence Turco

Louisiana State University and Agricultural \& Mechanical College

Follow this and additional works at: https://digitalcommons.Isu.edu/gradschool_disstheses

\section{Recommended Citation}

Turco, Timothy Lawrence, "Acceptability and Effectiveness of Group Contingencies for Improving Spelling Achievement." (1987). LSU Historical Dissertations and Theses. 4428.

https://digitalcommons.Isu.edu/gradschool_disstheses/4428

This Dissertation is brought to you for free and open access by the Graduate School at LSU Digital Commons. It has been accepted for inclusion in LSU Historical Dissertations and Theses by an authorized administrator of LSU Digital Commons. For more information, please contact gradetd@lsu.edu. 


\section{INFORMATION TO USERS}

While the most advanced technology has been used to photograph and reproduce this manuscript, the quality of the reproduction is heavily dependent upon the quality of the material submitted. For example:

- Manuscript pages may have indistinct print. In such cases, the best available copy has been filmed.

- Manuscripts may not always be complete. In such cases, a note will indicate that it is not possible to obtain missing pages.

- Copyrighted material may have been removed from the manuscript. In such cases, a note will indicate the deletion.

Oversize materials (e.g., maps, drawings, and charts) are photographed by sectioning the original, beginning at the upper left-hand corner and continuing from left to right in equal sections with small overlaps. Each oversize page is also filmed as one exposure and is available, for an additional charge, as a standard $35 \mathrm{~mm}$ slide or as a 17 "x 23" black and white photographic print.

Most photographs reproduce acceptably on positive microfilm or microfiche but lack the clarity on xerographic copies made from the microfilm. For an additional charge, $35 \mathrm{~mm}$ slides of 6" 9 " black and white photographic prints are available for any photographs or illustrations that cannot be reproduced satisfactorily by xerography. 
Order Number 8728224

Acceptability and effectiveness of group contingencies for improving spelling achievement

Turco, Timothy Lawrence, Ph.D.

The Louisiana State University and Agricultural and Mechanical Col., 1987 


\section{PLEASE NOTE:}

In all cases this material has been filmed in the best possible way from the avallable copy.

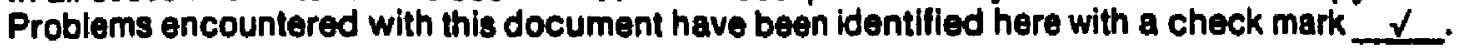

1. Glossy photographs or pages

2. Colored illustrations, paper or print

3. Photographs with dark background

4. Illustrations are poor copy

5. Pages with black marks, not original copy

6. Print shows through as there is text on both sides of page

7. Indistinct, broken or small print on several pages

8. Print exceeds margin requirements

9. Tightly bound copy with print lost in spine

10. Computer printout pages with indistinct print

11. Page(s) author. lacking when material received, and not available from school or

12. Page(s) seem to be missing in numbering only as text follows.

13. Two pages numbered . Text follows.

14. Curling and wrinkled pages

15. Dissertation contains pages with print at a slant, filmed as received

16. Other

\section{University Microfilms International}




\title{
Acceptability and Effectiveness of Group \\ Contingencies for Improving spelling Achievement
}

\author{
A Dissertation \\ Submitted to the Graduate Faculty of the \\ Louisiana State University and \\ Agricultural and Mechanical College \\ in partial fulfillment of the \\ requirements for the degree of \\ Doctor of Philosophy
}

in

The Department of Psychology

by

Timothy L. Turco

B.s., University of New Orleans, 1976

M.S., University of New Orleans, 1978

August 1987 


\section{Acknowledgement}

I would like to thank my wife Pam and my daughters, Heather and Janelle for their support throughout this course of study. I am also grateful for the technical assistance given to me by Brian F. Blowers.

This project would not have been possible without the assistance and approval of the administration, teachers, and parents of st. Charles Parish Public Schools. I am especially appreclative of the contributions of Coy L. Landry, Dr. Margaret Anderson, Gail Beck, Joan Robbins, Joyce Pierre, Karen Loup, Ms. Huth, Ms. Sampson, Ms. Guillory, Ms. Walsh, and Mr. Deroucher.

I would also like to recognize the contributions of Drs. Frances Beck, Frank M. Gresham, Mary Lou Kelley, and Joseph c. Witt, for critically evaluating this project.

I would like to especially thank my committee chairman, major professor, supervisor, mentor, and friend, stephen N. Elliott, for providing me with continued guidance, and an exemplary personal and professional model. 
LIST OF TABLES....................

IIST OF FIGURES.................... ix

ABSTRACT .......................

INTRODUCTION. .....................

Group Contingencies....................

Why Use Group Contingencies?......3

Types of Group Contingencies......4

Advantages and Disadvantages

of Group Contingencies..........5

Advantages...............

Disadvantages............. 5

Theoretical Factors Influencing

the Effectiveness of Group

Contingencies...............

Identifying Effective Group

Contingencies...............9

objective evaluation of

group contingencies.........9

Subjective evaluation of

group contingencies........20

Rationale for Additional

Group Contingency Research........29 
Cooperative Learning strategies... . . . . 32 Dimensions of Cooperative Learning. ...................... 33 Cooperative Learning Techniques....36 student Team Learning.......36 Jigsaw. .................... 37 Learning Together.............38 Group-Investigation.........38 Advantages and disadvantages.......39 Advantages. . . . . . . . . . 39

Disadvantages............41 Infusing the Group Contingency Paradigm with Cooperative Learning Theory........................42 Rationale for the Invention of the Present Research Problem...........43 Predictions....................45 METHOD..........................48 Design.......................48 subjects......................49 Experimental Teacher..............49 Materials......................49 
Procedures.....................53

Selection of schools...........53

Parent permission.............54

Group formation..............54

Social acceptability probe........57

Sociometric ratings of peers......58

Pretreatment WRAT-R Spelling

test........................ 58

orientation of experimental

group......................58

Pretesting................60

Reinforcers................61

Baseline 1 phase..............61

Baseline 2 phase.............61

Treatment phase.............63

Baseline 2 or Reversal phase......65

Treatment integrity assessment.....66

Variables and analysis...........66

Preliminary Analyses..........67

Major Analyses..............67

RESULTS........................72

Preliminary results..............72

spelling achievement

comparisons...............72 
Factor analysis of the CIRP......73

Reliability of the CIRP.........73

Treatment Integrity...........78

Major analysis and tests of

predictions................80

Acceptability ratings: Treatment

subgroups versus analogue

control group..............80

Treatment acceptability under

varying incentive and task

structure..................89

Effectiveness of treatments for

increasing spelling achievement...993

WRAT-R spelling.............94

Curriculum spelling...........95

Weekly unlt spelling...........98

Relation between acceptability ratings

and effectiveness of the

instructional treatments.........105

Sociometric ratings of peers within

treatment subgroups............107

Summary of results with respect to

major predictions............116

$v i$ 
DISCUSSION........................119

Major findings..................121

Acceptability....................121

spelling achievement..............122

Acceptability-effectiveness relation....123

Sociometric ratings................. 125

Comparison of present results with

previous research.............126

Limitations, shorcomings, and cautions

about this study..............133

Test-Retest reliably............133

Student attrition..............134

Experimental classroom...........135

stimulus words..............138

withdrawal design..............140

Generalizability..............140

Future research..................140

Implications of this study for applied research.................... 144

Conclusions and summary............146

REFERENCES. . . . . . . . . . . . . . . . . 149

APPENDIX A: Treatment acceptability

probe............................. 
APPENDIX B: Word lists used during this

study.........................170

APPENDIX c: Parent permission letter.......178

APPENDIX D: Experimental teacher scripts....180

APPENDIX E: Post hoc procedures to

prevent TYPE IV error.............183

VITA. .......................... 187

APPROVAL SHEETS. . . . . . . . . . . . . . . 195

viii 
Iist of Tables

Table 1. Summary of Group contingency

Research....................... 12

Table 2. Children's Intervention

Rating Profile..................52

Table 3. Sociometric Rating Forms......59

Table 4. Means and standard Deviation of Pretreatment wide Range Achievement

Test - Revised spelling subtest

standard scores..................74

Table 5. ANOVA Source Table for wide

Range Achievement Test - Revised as the

Dependent Variable with Group and Time

as the Independent Variables.........76

Table 6. Unrotated Factor Analysis of

the Children's Interventon Rating

Profile......................

Table 7. Test-Retest Reliability of the

Children's Intervention Rating Profile..79

Table 8. Pretreatment and Posttreatment

Children's Intervention Rating Profile

Scores for Each of the seven Treatment

subgroups.....................83

ix 
Table 9. Source Table for a Repeated Measures ANOVA Examining Pretreatment and Posttreatment Acceptability Ratings of students in Each Incentive structure and Task structure.........84

Table 10. Children's Intervention

Rating Profile Scores for Each of the Treatment Methods................86

Table 11. Source Table for the Results of a Series of One-Way ANOVA's Examining Pretreatment to Posttreatment Acceptability Rating Differences Between the students in the seven Treatment subgroups.....................88

Table 12. Pretreatment and Posttreatment Children's Intervention Rating Profile Scores for Each of the Incentive structures.....................90

Table 13. Source Table for a Repeated Measures ANOVA Examining Pretreatment and Posttreatment Acceptability Ratings of Students in Each Incentive structure and Task structure...............91 
Table 14. Pretreatment and Posttreatment Curriculum Spelling Test Scores for Each of the Seven Treatment Subgroups.......96 Table 15. Source Table for a Repeated Measures ANOVA Examining the Pretreatment and Posttreatment Curriculum Spelling Test Scores for Each of the seven Treatment Subgroups...97 Table 16. Correlations Among the Pretreatment and Posttreatment Total CIRP Scores and Curriculum spelling Test Scores for Each Instructional Treatment Method.................106 Table 17. Pretreatment and Posttreatment Social Preference Peer Ratings for Each of the Treatment Subgroups............108 Table 18. Source Table for a Repeated Measures ANOVA Examining Pretreatment and Posttreatment Social Preference Ratings of Students in Each Incentive Structure and Task structure..........110 Table 19. Pretreatment and Posttreatment Social Impact Peer Ratings for Each of the Treatment subgroups.............111 
Table 20. Source Table for a Repeated Measures ANOVA Examining Pretreatment and Posttreatment Social Impact Ratings of Students in Each Incentive structure and Task structure.........112

Table 21. Pretreatment to Posttreatment Changes in Social status for students in the Instructional Treatment subgroups.....................113 


\section{List of Figures}

Eigure 1. Dimensions of the Nature

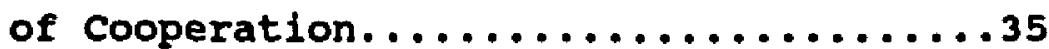

Eicure 2. Expanded Nature of

Cooperation Model................44

Figure 3. Subgroup Assignments for

subjects.....................56

Eiqure 4. Instruction and study Time

Integrity...................81

Figure 5. Mean Children's Intervention

Rating Profile Scores for Each Treatment

Method.......................85

Eicure 6. Weekly spelling performances

for the interdependent group treatment

subgroup. ......................99

Figure 7. Weekly spelling performances

for the dependent group treatment

subgroup........................ 100

Fiqure 8. Weekly spelling performances

for the no incentive group treatment

subgroup......................101

Fiqure 9. Weekly spelling performances

for the interdependent individual

treatment subgroup...............102 
Figure 10. Weekly spelling performances

for the dependent individual treatment

subgroup.......................103

Fiqure 21. Weekly spelling performances

for the no incentive individual

treatment subgroup.................104

xiv 


\section{Abstract}

This 12-week study conceptually merged cooperative learning and group contingency approaches to classroom interventions to assess how varying task and incentive structures affect fifth-grade students' speljing achievement, social status, and perceptions of treatment procedures. The study used two groups (treatment and control group) of fifth-grade students. The students in the treatment group were actively involved with one of six group contingency procedures designed to improve spelling performances. The conditions for students in the treatment groups varied on dimensions of task structure (group or individual) and incentive structure (interdependent, dependent, or no incentive). Treatment acceptability, spelling achievement, and peer nominated social status were assessed in all students during pretreatment and posttreatment phases.

The results of the study indicated that the pretreatment acceptability ratings of all the treatment groups were not significantly different from the acceptability ratings of the control group. All of the treatment subgroups, except the 
dependent individual subgroup, showed significant decreases in acceptability from pretreatment to posttreatment. The acceptability ratings of the control group did not significantly change from pretreatment to posttreatment.

The spelling performances of all groups increased significantly from pretreatment to posttreatment on the WRAT-R and a curriculum spelling test. However, no significant increases in weekly spelling achievement were found in any of the treatment subgroups as a result of either the incentive structure or the task structure.

The overall results also indicated that, based on the peer nominations, the various incentive structures and task structures did not lead to significant changes in social impact, social preference, or social status. Some individuals' rated social status did change in positive directions, whereas, nearly an equal number changed in a negative direction.

This study has begun to answer several important questions about the nature of treatment acceptability ratings and group contingencies. It was concluded that students' acceptability ratings 
are fairly stable over time, but do change significantly as a result of exposures to the treatments. Thus, experience with a particular treatment, seems to be a meaningful factor in the evaluation of a treatment. The results of spelling acheivement measures and acceptability ratings indicates that the interdependent group treatment method is the best or most preferred method. 
The present study conceptually merged cooperative learning and group contingency approaches to classroom interventions to assess how varying task and incentive structures affect fifth-grade students' spelling achievement, social status, and perceptions of treatment procedures. Group contingencies and cooperative learning techniques have evolved separately, with the group contingency methods originating from applied behavioral analysis and the cooperative learning methods developing from social psychological and educational practices. Incorporating the group contingency paradigm into the cooperative learning framework unites two parallel, but yet unlinked approaches and results in a multidimensional conceptualization of group interventions.

In response to the increasing demands for academic interventions that are efficient and sensitive to the time constraints of the classroom environment, the use of group contingent treatment techniques is becoming more prevalent. According to applied behaviorists, there are three types of group contingencies: (a) 
Independent, (b) dependent, and (c)

interdependent (Litow Pumroy, 1975). Thus far, the group contingency literature has been

atheoretical and unidimensional. Consequently, the growth of research within the group contingency paradigm has been limited.

A parallel, and somewhat similar, theoretical perspective on classroom group interventions has evolved from group process research in social psychology and has been called cooperative learning. This perspective emphasizes that students can learn efficiently when they work together (Slavin, 1985). Cooperative learning philosophy seeks to evaluate instructional situations across 25 or more dimensions. One of these dimensions, incentive structures, includes all of the group contingencies that Litow and Pumroy (1975) defined, except the dependent group contingency. The similarities of the incentive structures of the cooperative learning theory to those in the group contingencies paradigm, may indicate that other cooperative learning dimensions may be infused with the group contingency paradigm. 
This encorporation of the two dimensions creates a multidimensional model that provides a new perspective on the group contingency paradigm.

The applicability of cooperative learning theory to the advancement of the study of group contingencies is a matter of theoretical and empirical evaluation. The present study integrated the group contingency paradigm with the nature of cooperation dimension (i.e., task structure) of the cooperative learning theory to create a two dimensional perspective of group contingencies.

The following section briefly will examine the origins of the group contingency paradigm and cooperative learning theory. I will then review the group contingency literature relating to the improvement of academic achievement, particularly in the area of spelling. Group Contingencies Why Use Group contingencies?

Most classroom systems designed to improve academic performance or behaviors typically reinforce an individual rather than a group (Grandy, Madsen, \& Mersseman, 1973). Many of the 
individual intervention techniques that have been designed for use in school settings, however, have been prohibitively time consuming for the teacher and expensive (Litow Pumroy, 1975; Wasik, 1970). The financial and logistical limitations of many public schools requires that interventions be devised which allow as many children as possible to be managed by as few adults as possible (Quay, Werry, McQueen, \& Sprague, 1966). Therefore, the use of effective group interventions in the classroom setting may be a matter of necessity as well as convenience (Hall, Lund, Jackson, 1968) and thus, the use of group contingencies is increasing (Neumann, 1977).

Types of Group Contingencies

Based on Bandura's (1969) classification system, Litow and Pumroy (1975) identified three major types of group contingencies: (a) dependent, where the group's attainment of a reward depends upon the performances of a target student or students meeting a specified criterion, (b) interdependent, where the group's attainment of a reward depends upon every member 
of the group meeting a specified criterion or alternatively, the group's average performance exceeding the criterion, and (c) independent, where each member of the group's attainment of the reward depends upon his/her own performance meeting or exceeding the specified criterion. Advantages and Disadvantages of Group

\section{Contingencies}

Advantages. Gresham and Gresham (1982) noted that the dependent and interdependent group contingencies have at least two advantages over other intervention techniques. First, because students are organized into groups, the group contingency programs require less teacher time and attention in monitoring and charting behaviors and distributing rewards (Barrish, Saunders, \& Wolf, 1969; Grandy et al., 1973; Harris \& Sherman, 1973; Packard, 1970). Second, the fact that students in group contingencies are working in groups to attain good classroom behaviors, sets the occasion for peers to act as behavior change agents.

Disadvantages. Several disadvantages also exist for group contingencies. First, the poor 
behaviors of a single student can prevent the entire group from obtaining a reward (Crouch, Gresham, \& Wright, 1985). In some situations, a student may try purposefully to prevent the group from obtaining a reward. A second major disadvantage of group contingencies is that once groups perceive that they have lost the reinforcement for a particular day, they may no longer be motivated to maintain their behavioral or academic efforts (Crouch et al., 1985).

Some research indicates that group contingencies may lead to peer pressures that may be either detrimental (Axelrod, 1973; Packard, 1970; Shores, Apolloni, Norman, 1976) or facilitative (Evans \& Oswalt, 1968; McCarty, Griffin, Apolloni, \& Shores, 1977; Pigott, Fantuzzo, clement, 1986; Sloggett, 1971) to the academic environment. The directionality and extent of classroom peer influences seem to vary with the social characteristics of the students and the nature of the task. 
Theoretical Factors Influencing the Effectiveness of Group Contingencies

Ideally, students in a group treatment will receive group pressures to either comply or conform to the goals of the group. Compliance is where students perform some task because they are asked (Sears, Freedman, \& Peplau, 1985). In a cooperative incentive structure, compliance can be initiated and maintained through a number of means. For example, students may comply with the demands of a teacher or another student in the class recognized as holding legitimate authority (Milgram, 1963) . Also, students may comply to receive rewards and to avoid punishments. Within limits, the stronger the rewards or punishments, the more students will comply. When the incentives become excessive or cease to be provided, compliance is reduced (Brehm, 1966; Deci, 1971; Lepper, Greene, Nisbett, 1973). Conformity refers to where a student performs an act because other students are also doing it (Sears et al., 1985). Social psychologists hypothesize that students will conform to group or peer pressures for two basic 
reasons. First, the behaviors of students in the group provides useful information to other students in the group (Sears et al, 1985). For example, during a cooperative incentive treatment, a student having difficulty working mathematics problems, may conform to the demands of the group in order to do better in mathematics. The second reason students conform to the demands of the group is to gain social acceptance and to avoid disapproval (Sears et al., 1985). Several factors contribute to how effective social acceptance is upon the behaviors of group members. First, greater group cohesiveness leads to greater conformity. Cohesiveness refers to the sum total of all the forces that cause students to want to be a member of the group. When the students in the group are working toward a valued reward, conformity to the group's demands is high.

Group size also seems to influence conformity, but unfortunately, no consensus has been reached as to the optimal size of groups. Some studies have indicated that between three and five group members is optimal (Asch, 1951; 
Mann, 1977), but other studies have Indicated that the larger the group size, the stronger the peer influences (Milgram, Bickman, \&erkowitz, 1969).

\section{Identifying Effective Group Contingencies}

The identification of effective group contingencies is a matter of both objective and subjective evaluation. Objective evaluation includes the use of statistical or graphical analysis of the results of group treatments. Subjective evaluation includes the use of interview, anecdotal, or paper and pencil tasks to assess how the consumers of a group treatment feel about the treatment's use or importance (Wolf, 1978).

\section{objective evaluation of group}

contingencies. Several objective measures have been used to evaluate the ability of group contingencies to improve academic performances. The results of these studies have generally been positive. Group contingencies improve academic performances above baseline levels (Allen, McLaughlin, Harman, 1980; Chadwick \& Day, 1971; Evans \& Oswalt, 1968; Hamblin \& Smith, 1972; 
Haring \& Hauck, 1969; Harris \& Sherman, 1973; Hopkins, Schutte, Garton, 1971; Lovitt, Guppy, \& Blettner, 1969; McCarty, Griffin, Apolloni, \& Shores, 1977; McLaughlin, 1981; Meloney \& Hopkins, 1973; Sloggett, 1971; Wodarski, Hamblin, Buckholdt, Ferritor, 1973). No clear evidence exists in the literature that demonstrates one group contingency is superior to the other for improving academic performances (Allen et al., 1980; Greenwood \& Hops, 1981; Lovitt et al., 1969; McCarty et al., 1977; McLaughlin, 1981; sloggett, 1971; Wodarski et al., 1973).

A number of variables should be considered when reviewing group contingency studies. For example, Pigott and Heggie (1986) reported that the lack of empirical evidence showing a superiority of one group contingency over another is due to reviewers' (Greenwood Hops, 1981; Hayes, 1976; Litow \& Pumroy, 1975; McLaughlin, 1974) failure to differentiate between studies based on the characteristics of the treated behaviors. Pigott and Heggie (1986) reported that when the data from classroom group contingency studies were evaluated, 
interdependent contingencies were superior to independent contingencies. However, their conclusions appear to be based on the analysis of a limited number of studies with weak treatment differences.

Table 1 summarizes the results of 20 classroom group contingency studies using objective measures to assess academic achievement. Notice that all of the studies presented in Table 1 provided rewards to students for appropriate behaviors. Unfortunately, however, beyond this point, direct comparisons of the studies presented in Table 1 are difficult because the studies differ on several potentially important characteristics. For example, consider the the size of the groups. In Table 1 the sizes of the groups varied from 1 to 33 students. If the social psychological theories are correct and group size does effect peer pressure and conformity, the numbers of students in the groups compared may be a critical factor. No investigator, however, has yet evaluated systematically the influences of group size on the efficacy of academic group contingencies. 
Sugegary of Grouge Contingency Research

\begin{tabular}{|c|c|c|c|c|c|}
\hline Study & Subjects & $\begin{array}{l}\text { Dependent } \\
\text { Variables }\end{array}$ & Design & $\begin{array}{l}\text { Independent } \\
\text { Varjables }\end{array}$ & Results \\
\hline $\begin{array}{l}\text { Allen, } \\
\text { RcLaughlin, } \\
\& \text { Harton, } \\
1990\end{array}$ & $\begin{array}{l}9 \text { behavior } \\
\text { disordered } \\
8 \text { to } 11 \\
\text { year olds }\end{array}$ & $\begin{array}{l}\text { 1-nuber of } \\
\text { letters } \\
\text { correctly } \\
\text { witten }\end{array}$ & $A B C D$ & $\begin{array}{l}\text { A-baseline } \\
\text { B-DRH } \\
\text { (interdependent) } \\
\text { C-DRO } \\
\text { (independent) } \\
\text { D-DRH } \\
\text { (independent) }\end{array}$ & $\begin{array}{l}\text { 1-interdependent and } \\
\text { indapendent DRH } \\
\text { increased the } \\
\text { number of correctly } \\
\text { written letters } \\
\text { frou baseline } \\
\text { levels }\end{array}$ \\
\hline $\begin{array}{l}\text { Broughton, } \\
1983\end{array}$ & $\begin{array}{l}6 \text { regular } \\
\text { class 4th } \\
\text { graders }\end{array}$ & $\begin{array}{l}\text { 1-ath } \\
\text { perforance }\end{array}$ & $A B$ & $\begin{array}{l}\text { A-baseline } \\
\text { B-contingent } \\
\text { teacher } \\
\text { attention } \\
\text { (independent) }\end{array}$ & $\begin{array}{l}\text { 1-independent } \\
\text { contingency } \\
\text { increased } \\
\text { math } \\
\text { performance }\end{array}$ \\
\hline $\begin{array}{l}\text { Chadwick \& } \\
\text { Day, } 197 !\end{array}$ & $\begin{array}{l}11 \text { black } \\
14 \text { hispanic } \\
8 \text { to } 12 \text { year } \\
\text { old } \\
\text { under- } \\
\text { achievers }\end{array}$ & $\begin{array}{l}\text { 1-tive on task } \\
\text { 2-nuaber of } \\
\text { nath problens } \\
\text { per einuta } \\
\text { 3-percent of } \\
\text { ath probless } \\
\text { correct }\end{array}$ & $\mathrm{ABC}$ & $\begin{array}{l}\text { A-baseline } \\
\text { B-token } \\
\text { reinforcenent } \\
\text { (independent) } \\
\text { C-social } \\
\text { reinforceaent }\end{array}$ & $\begin{array}{l}\text { l-independent } \\
\text { contingency } \\
\text { increased } \\
\text { acadenics nore } \\
\text { than baseline } \\
\text { or social } \\
\text { reinforcenent }\end{array}$ \\
\hline $\begin{array}{l}\text { Evans } \\
\text { Oswalt, } \\
1968\end{array}$ & $\begin{array}{l}32 \text { students } \\
\text { in } 4 \text { th grade } \\
\text { spelling }\end{array}$ & $\begin{array}{l}\text { 1-number of } \\
\text { words spelled } \\
\text { correctly }\end{array}$ & $A B C$ & $\begin{array}{l}\text { A-baseline } \\
\text { B-early release } \\
\text { from class } \\
\text { contingent upon } \\
\text { the performances } \\
\text { of student 1 } \\
\text { (dependent) } \\
\text { C-early release } \\
\text { fros class } \\
\text { contingent upon } \\
\text { the performances } \\
\text { of student } 2 \\
\text { (dependent) }\end{array}$ & $\begin{array}{l}\text { 1-target student's } \\
\text { perfornances } \\
\text { ioproved during } \\
\text { dependent } \\
\text { contingency } \\
\text { 2-target student's } \\
\text { perforoances } \\
\text { dropped to } \\
\text { baseline levels } \\
\text { wen the } \\
\text { contiagency was } \\
\text { resoved } \\
\text { 3-dependent } \\
\text { contingency had } \\
\text { no effect on } \\
\text { non-target students }\end{array}$ \\
\hline
\end{tabular}




\begin{tabular}{|c|c|c|c|c|c|}
\hline Study & Subjects & $\begin{array}{l}\text { Dependent } \\
\text { Variables }\end{array}$ & Design & $\begin{array}{l}\text { Independent } \\
\text { Variables }\end{array}$ & Results \\
\hline $\begin{array}{l}\text { Evans } 1 \\
\text { Dswalt, } \\
1968\end{array}$ & $\begin{array}{l}30 \text { students } \\
\text { in 4th grade } \\
\text { eath }\end{array}$ & $\begin{array}{l}\text { 1-nuber of } \\
\text { ath probless } \\
\text { correct }\end{array}$ & $A B C$ & $\begin{array}{l}\text { A-baseline } \\
\text { B-early release } \\
\text { froa class } \\
\text { contingent upon } \\
\text { student 1 } \\
\text { (dependent) } \\
\text { C-early release } \\
\text { from class } \\
\text { contingent upon } \\
\text { student } 2 \\
\text { (dependent) }\end{array}$ & $\begin{array}{l}\text { 1-target student's } \\
\text { perforaance } \\
\text { ioproved during } \\
\text { dependent } \\
\text { contingency } \\
\text { 2-target student's } \\
\text { perforance dropped } \\
\text { to baseline level } \\
\text { when the dependent } \\
\text { contingency was } \\
\text { recoved } \\
\text { 3-dependent } \\
\text { contingency had } \\
\text { no effect on } \\
\text { non-target students }\end{array}$ \\
\hline $\begin{array}{l}\text { Evans : } \\
\text { Dswalt, } \\
1968\end{array}$ & $\begin{array}{l}34 \text { students } \\
\text { in bth grade } \\
\text { social studies }\end{array}$ & $\begin{array}{l}\text { 1-nuaber of } \\
\text { social } \\
\text { studies } \\
\text { probleas } \\
\text { correct }\end{array}$ & $A B$ & $\begin{array}{l}\text { A-baseline } \\
\text { B-early release } \\
\text { fron class } \\
\text { contingent upon } \\
\text { the perforaances } \\
\text { of student } 1 \\
\text { (dependent) }\end{array}$ & $\begin{array}{l}\text { 1-target student's } \\
\text { perforaances } \\
\text { ioproved during } \\
\text { the dependent } \\
\text { contingency } \\
\text { 2-target student's } \\
\text { perfornances } \\
\text { dropped to } \\
\text { basel ine levels } \\
\text { when the } \\
\text { dependent } \\
\text { contingency was } \\
\text { reapved } \\
\text { 3-dependent } \\
\text { contingency had } \\
\text { no effect on } \\
\text { non-target } \\
\text { students' } \\
\text { perforaances }\end{array}$ \\
\hline
\end{tabular}


Table 1 (continued)

\begin{tabular}{|c|c|c|c|c|c|}
\hline Study & Subjects & $\begin{array}{l}\text { Dependent } \\
\text { Variables }\end{array}$ & Design & $\begin{array}{l}\text { Independent } \\
\text { Variables }\end{array}$ & Results \\
\hline $\begin{array}{l}\text { Evans } \\
\text { Oswalt, } \\
1968\end{array}$ & $\begin{array}{l}34 \text { students } \\
\text { in 6th grade } \\
\text { sci ence }\end{array}$ & $\begin{array}{l}\text { 1-nuaber of } \\
\text { science } \\
\text { questions } \\
\text { correctly } \\
\text { answered }\end{array}$ & $A B$ & $\begin{array}{l}\text { A-baseline } \\
\text { B-early release } \\
\text { frou class } \\
\text { contingent upon } \\
\text { the performances } \\
\text { of student } 1 \\
\text { (dependent) }\end{array}$ & $\begin{array}{l}\text { 1-contingent } \\
\text { and noncontingent } \\
\text { students" } \\
\text { perfornances } \\
\text { declined during } \\
\text { dependent group } \\
\text { contingency }\end{array}$ \\
\hline $\begin{array}{l}\text { Haring } 8 \\
\text { Hauck, } \\
1969\end{array}$ & $\begin{array}{l}\text { four Jro } \\
\text { to 5th } \\
\text { graders }\end{array}$ & $\begin{array}{l}\text { 1-number of } \\
\text { correct } \\
\text { reading } \\
\text { questions }\end{array}$ & ABCDEF & $\begin{array}{l}\text { A-progranned text } \\
\text { without answers } \\
\text { (Baseline () } \\
\text { B-progranned text } \\
\text { with answers } \\
\text { (Baseline 2) } \\
\text { C-progranned text } \\
\text { with counters } \\
\text { (Baseline 3) } \\
\text { D-progranued text } \\
\text { with continuous } \\
\text { reinforcenent } \\
\text { token econony } \\
\text { (independent) } \\
\text { E-progranned text } \\
\text { with variable } \\
\text { ratio token } \\
\text { econony } \\
\text { (independent) } \\
\text { F-basal reader with } \\
\text { variable ratio } \\
\text { token econony } \\
\text { (independent) }\end{array}$ & $\begin{array}{l}\text { 1-independent } \\
\text { contingencies } \\
\text { resulted in } \\
\text { increased correct } \\
\text { reading } \\
\text { responses }\end{array}$ \\
\hline
\end{tabular}


Table 1 (continued)

\begin{tabular}{|c|c|c|c|c|c|}
\hline Study & Subjects & $\begin{array}{l}\text { Dependent } \\
\text { Variables }\end{array}$ & Design & $\begin{array}{l}\text { Independent } \\
\text { Variables }\end{array}$ & Results \\
\hline $\begin{array}{l}\text { Harris } 4 \\
\text { Shernan, } \\
1973\end{array}$ & $\begin{array}{l}30 \text { 5th } \\
30 \text { 6th } \\
\text { graders in } \\
\text { math } \\
\text { English }\end{array}$ & $\begin{array}{l}\text { 1-disfuptive } \\
\text { behavior } \\
\text { 2-atadebic } \\
\text { performances }\end{array}$ & $A B$ & $\begin{array}{l}\text { A-baseline } \\
\text { B-differential } \\
\text { reinforceaent } \\
\text { of low rates } \\
\text { of responding } \\
\text { good behavior } \\
\text { gane } \\
\text { linterdependent) }\end{array}$ & $\begin{array}{l}\text { 1-interdependent } \\
\text { contingency } \\
\text { increased } \\
\text { acadeaic } \\
\text { perforaance } \\
\text { 2-interdependent } \\
\text { contingency } \\
\text { decreased } \\
\text { disruptive } \\
\text { behaviors }\end{array}$ \\
\hline $\begin{array}{l}\text { Hopkins, } \\
\text { Schutte, } \\
\text { Garton, } \\
1971\end{array}$ & $\begin{array}{l}14 \text { 1st } \\
102 \text { nd } \\
\text { graders }\end{array}$ & $\begin{array}{l}\text { 1-errors per } \\
\text { latter } \\
\text { printed } \\
\text { 2-nunber of } \\
\text { letters } \\
\text { printed } \\
\text { per ainute }\end{array}$ & $\begin{array}{l}\text { changing } \\
\text { criterion } \\
\text { with a } \\
\text { baseline } \\
\text { \& reversal }\end{array}$ & $\begin{array}{l}\text { 1-baseline/reversal } \\
\text { 2-contingent } \\
\text { release to } \\
\text { playroon } \\
\text { (independent) }\end{array}$ & $\begin{array}{l}\text { 1-independent } \\
\text { group } \\
\text { contingency } \\
\text { increased } \\
\text { the speed and } \\
\text { accuracy of } \\
\text { responses }\end{array}$ \\
\hline $\begin{array}{l}\text { Lovitt, } \\
\text { Guppy, } \\
\text { Blettner, } \\
1969\end{array}$ & $\begin{array}{l}32 \text { regular } \\
\text { education } \\
\text { 4th graders }\end{array}$ & $\begin{array}{l}\text { 1-number of } \\
\text { perfect } \\
\text { papers }\end{array}$ & $A B C$ & $\begin{array}{l}\text { A-traditional } \\
\text { treatuent } \\
\text { (baseline) } \\
\text { B-independent } \\
\text { C-interdependent }\end{array}$ & $\begin{array}{l}\text { 1-both group } \\
\text { contingencies } \\
\text { increased the } \\
\text { number of } \\
\text { perfect papers } \\
\text { above baseline } \\
\text { levels } \\
\text { 2-no difference } \\
\text { between independent } \\
\text { and interdependent } \\
\text { group contingencies }\end{array}$ \\
\hline
\end{tabular}




\begin{tabular}{|c|c|c|c|c|c|}
\hline Study & Subjects & $\begin{array}{l}\text { Dependent } \\
\text { Variables }\end{array}$ & Design & $\begin{array}{l}\text { Independent } \\
\text { Vari ables }\end{array}$ & Results \\
\hline $\begin{array}{l}\text { nelarty, } \\
\text { 6riffin, } \\
\text { Apolloni, } \\
\& \text { Shores, } \\
1977\end{array}$ & $\begin{array}{l}4 \text { behavior } \\
\text { disordered } \\
\text { adolescent } \\
\text { inpatients }\end{array}$ & $\begin{array}{l}\text { 1-nuber of } \\
\text { nath } \\
\text { probleas } \\
\text { correct }\end{array}$ & ABAC & $\begin{array}{l}\text { A-baseline } \\
\text { B- } \mathbf{6 . 0 5} \text { per correct } \\
\text { problea } \\
\text { (independent) } \\
\text { C- } \$ .05 \text { per correct } \\
\text { probles after } \\
\text { every student } \\
\text { gets } 3 \text { probleas } \\
\text { correct } \\
\text { (aixed } \\
\text { independent and } \\
\text { interdependent) }\end{array}$ & $\begin{array}{l}\text { 1-group contingencies } \\
\text { increased the } \\
\text { nubber of correct } \\
\text { adh probleas } \\
\text { frow baseline } \\
\text { levels }\end{array}$ \\
\hline $\begin{array}{l}\text { MeLaughlin, } \\
1981\end{array}$ & $\begin{array}{l}10 \text { special } \\
\text { education } \\
9 \text { to } 11 \\
\text { year olds }\end{array}$ & $\begin{array}{l}\text { 1-reading } \\
\text { accuracy }\end{array}$ & $A B C$ & $\begin{array}{l}\text { A-baseline } \\
\text { B-independent } \\
\text { C-interdependent }\end{array}$ & $\begin{array}{l}\text { 1-group contingencies } \\
\text { increased reading } \\
\text { accuracy above } \\
\text { baseline levels } \\
\text { 2-interdependent } \\
\text { group contingency } \\
\text { was core effective } \\
\text { than the } \\
\text { independent group } \\
\text { contingency }\end{array}$ \\
\hline $\begin{array}{l}\text { Haloney } \\
\text { Hopkins, } \\
1973\end{array}$ & $\begin{array}{l}14 \text { th } \\
\text { to } 6 \text { th } \\
\text { graders }\end{array}$ & $\begin{array}{l}\text { 1-aean nunber } \\
\text { sentence } \\
\text { parts written }\end{array}$ & $A B$ & $\begin{array}{l}\text { A-baseline } \\
\text { B-differential } \\
\text { reinforcenent } \\
\text { of high rates } \\
\text { of responding } \\
\text { good writing } \\
\text { gane } \\
\text { (interdependent) }\end{array}$ & $\begin{array}{l}\text { 1-interdependent } \\
\text { group } \\
\text { contingency } \\
\text { increased } \\
\text { acadenic } \\
\text { perfornance } \\
\text { above baseline } \\
\text { levels }\end{array}$ \\
\hline
\end{tabular}


Table I (continued)

\begin{tabular}{|c|c|c|c|c|c|}
\hline Study & Subjects & $\begin{array}{l}\text { Dependent } \\
\text { Variables }\end{array}$ & Design & $\begin{array}{l}\text { Independent } \\
\text { Variables }\end{array}$ & Results \\
\hline $\begin{array}{l}\text { Pigott, } \\
\text { Fantuzzo, } \\
\text { L Clement, } \\
1984\end{array}$ & $\begin{array}{l}\text { 3! regular } \\
\text { education } \\
\text { 5th graders }\end{array}$ & $\begin{array}{l}\text { 1-eath } \\
\text { perforance } \\
\text { 2-accuracy of } \\
\text { procedures } \\
\text { 3-accuracy of } \\
\text { student } \\
\text { reinforcenent } \\
\text { 4-peer } \\
\text { affiliation }\end{array}$ & ABAB & $\begin{array}{l}\text { A-baseline } \\
\text { B-student } \\
\text { adninistered } \\
\text { group } \\
\text { contingency } \\
\text { (interdependent) }\end{array}$ & $\begin{array}{l}\text { 1-increases in } \\
\text { wath perforance } \\
\text { with group } \\
\text { contingency }\end{array}$ \\
\hline $\begin{array}{l}\text { Pigott, } \\
\text { Fantuzio, } \\
\text { \& Clenent, } \\
1986\end{array}$ & $\begin{array}{l}93 \text { fifth } \\
\text { graders }\end{array}$ & $\begin{array}{l}\text { 1-accuracy of } \\
\text { ath problews }\end{array}$ & ABAB & $\begin{array}{l}\text { A-basaline } \\
\text { B-reciprocal } \\
\text { peer tutoring } \\
\text { (interdependent) }\end{array}$ & $\begin{array}{l}\text { 1-interdependent } \\
\text { group } \\
\text { contingency } \\
\text { increased uath } \\
\text { performances } \\
\text { above baseline } \\
\text { levels }\end{array}$ \\
\hline $\begin{array}{l}\text { Shapiro } \\
\text { Soldberg, } \\
1986\end{array}$ & $\begin{array}{l}33 \text { regular } \\
\text { education } \\
\text { 6th graders }\end{array}$ & $\begin{array}{l}\text { 1-daily } \\
\text { spelling } \\
\text { score }\end{array}$ & ABAC & $\begin{array}{l}\text { A-baseline } \\
\text { B-alternating } \\
\text { treatuents } \\
\text { phase } \\
\text { (independent, } \\
\text { dependent, } \\
\text { interdependent) } \\
\text { C-independent }\end{array}$ & $\begin{array}{l}\text { 1-all group } \\
\text { contingencies } \\
\text { increased } \\
\text { spelling } \\
\text { perforances } \\
\text { above baseline } \\
\text { levels } \\
\text { 2-no contingency } \\
\text { was ore effective } \\
\text { than another }\end{array}$ \\
\hline
\end{tabular}


Table 1 (continued)

\begin{tabular}{|c|c|c|c|c|c|}
\hline Study & Subjects & $\begin{array}{l}\text { Dependent } \\
\text { Varjables }\end{array}$ & Design & $\begin{array}{l}\text { Independent } \\
\text { Variables }\end{array}$ & Results \\
\hline $\begin{array}{l}\text { Shapira } \\
\text { Goldberg, } \\
1987\end{array}$ & $\begin{array}{l}\text { 15 regular } \\
\text { education } \\
\text { 6th graders }\end{array}$ & $\begin{array}{l}\text { 1-daily } \\
\text { spelling } \\
\text { score }\end{array}$ & ABAC & $\begin{array}{l}\text { A-baseline } \\
\text { g-alternating } \\
\text { treatnents } \\
\text { phase } \\
\text { Idependent or } \\
\text { interdependent } \\
\text { alternating } \\
\text { large and } \\
\text { sall group) } \\
\text { C-alternating } \\
\text { treatuent phase } \\
\text { (dependent or } \\
\text { interdependent } \\
\text { with alternating } \\
\text { large and saall } \\
\text { group) }\end{array}$ & $\begin{array}{l}\text { 1-all group } \\
\text { contingencies } \\
\text { increased } \\
\text { spelling } \\
\text { performances } \\
\text { above baselife } \\
\text { levels } \\
\text { 2-no group } \\
\text { contingency } \\
\text { was eore effective } \\
\text { than another }\end{array}$ \\
\hline $\begin{array}{l}\text { Sloggett, } \\
1971\end{array}$ & $\begin{array}{l}34 \text { self- } \\
\text { contained } \\
\text { males with } \\
\text { behavior } \\
\text { \& acadeaic } \\
\text { problews }\end{array}$ & $\begin{array}{l}\text { 1-eath } \\
\text { achievenent } \\
\text { 2-productivity } \\
\text { 3-behavior }\end{array}$ & $\begin{array}{l}2 \times 3 \\
\text { split- } \\
\text { plot }\end{array}$ & $\begin{array}{l}\text { Period } \\
\text { (a) pretreataent } \\
\text { (b) posttreataent } \\
\text { Contingency } \\
\text { (a) individual } \\
\text { (b) interdependent } \\
\text { (c) oixed } \\
\text { individual and } \\
\text { interdependent }\end{array}$ & $\begin{array}{l}\text { 1-all group } \\
\text { contingencies } \\
\text { increased } \\
\text { acadenic } \\
\text { achievenent } \\
\text { 2-no differences } \\
\text { between the } \\
\text { group } \\
\text { contingencies } \\
\text { in effectiveness }\end{array}$ \\
\hline $\begin{array}{l}\text { Nolfe, } \\
\text { Fantuz20, } \\
\text { \& Nolter, } \\
1984\end{array}$ & $\begin{array}{l}\text { four } \\
\text { 5th } \\
\text { graders }\end{array}$ & $\begin{array}{l}\text { 1-nath } \\
\text { perforances } \\
\text { 2-disruptive } \\
\text { behaviors }\end{array}$ & ABAB & $\begin{array}{l}\text { A-baseline } \\
\text { B-self } \\
\text { adeinistered } \\
\text { rewards } \\
\text { (interdependent) }\end{array}$ & $\begin{array}{l}\text { 1-interdependent } \\
\text { contingency } \\
\text { produced increased } \\
\text { math perforaances } \\
\text { 2-disruptive } \\
\text { behaviors } \\
\text { decteased with } \\
\text { increases in } \\
\text { wath perforances }\end{array}$ \\
\hline
\end{tabular}


Despite the procedural differences in the studies in Table 1, only one of the studies (i.e., McLaughlin, 1981) showed any clear superiority of a particular contingency McLaughlin (1981) used an alternating treatments design to compare the efficacy of an independent and an interdependent incentive structure to improve reading performance in elementary school-aged special education students. Reading performance was based upon the number of correct frames divided by the number of frames attempted in the students' programmed reading workbook. A token economy was used in the classroom. During the baseline phase, the students didn't receive tokens contingent upon reading performances. However, during the independent group contingency, students earned tokens in accordance with their own performances and during the interdependent group contingency, the students earned tokens based upon the classes average reading performance. The results indicated that the students' reading performances were significantly greater during the interdependent group contingency than during the independent 
group contingency or during the baseline phase.

subjective evaluation of group

contingencies. Social validations by the recipients or consumers of group interventions has become an important factor in evaluating an intervention. Wolf (1978) defined three dimensions of social validity. The first two of these dimensions, social significance and social appropriateness, are pretreatment measures. Social significance or societal acceptability, refers to whether the specific goals of the intervention are really what society wants. Appropriateness or consumer acceptability questions whether "the ends justify the means...[or if] the participants, caretakers, and other consumers consider the treatment procedures acceptable" (Wolf, 1978, p. 207). Kazdin (1980a) stated that acceptability concerns "whether [a] treatment is appropriate for the problem, whether it is fair, reasonable, or intrusive, and whether it is consistent with conventional notions of what treatment should be" (pp. 329-330).

Wolf's (1978) final social validity 
dimension, satisfaction, is a posttreatment measure. Satisfaction concerns the consumer's satisfaction with the results of the treatment or the "social importance of the effects" (Wolf, 1978, p. 207).

To date, only one scale has been published that has been designed specifically to measure the social validation judgments of children, the Children's Intervention Rating Profile (CIRP) (witt \& Elliott, 1983). The CIRP is a seven question, one-factor, six-point Likert scale of children's social acceptability ratings ranging from "I Agree" to "I Do Not Agree." The CIRP represents an objective social validation instrument that has been validated on over 1000 students in the fifth through tenth grades and found to have an average coefficient alpha of .86 (Turco \& Elliott, 1986b). Published studies have used the CIRP successfully to assess the acceptability ratings of children (Elliott, witt, Galvin, \&oe, 1986; Shapiro \&oldberg, 1986; Turco \& Elilott, 1986a; Turco \& Elliott, 1986b). The vast majority of studies using group contingencies have not reported any social 
validity data or qualitative analysis. Almost all of the group contingency studies that have social validation data have focused on behavioral problems (Drabman, Spitalnik spitalnik, 1974; Elliott, Witt, Galvin, \& Moe, 1986 ; Elliott, Turco, \& Gresham, in press). To date, only two groups of researchers have assessed the social validity of group treatments for academic performances (McLaughlin, 1982; Shapiro \& Goldberg, 1986, 1987).

McLaughlin (1982) used a multiple baseline design to evaluated the efficacy of an independent and interdependent group contingency for increasing the number of correctly spelled words in 10 special education students, 9 to 10 years of age. In the independent group contingency, each student earned one point for each correctly spelled word. In the interdependent group contingency, group points were awarded based on the average performances of the group. At the end of the study, each student rated $\mathrm{his} / \mathrm{her}$ satisfaction with each of the group contingencies on a 7-point Likert scale. The results of McLaughlin's (1982) study indicated 
that the interdependent group contingency consistently resulted in higher numbers of spelling words correct than in the baseline or independent group contingency. No differences between the contingencies were found in the students' ratings of satisfaction. Unfortunately, there are some problems with the Mclaughlin (1982) study. First, the design of the study confounded the type of task structure with the type of group contingency. Therefore, it cannot be determined whether the observed differences between the contingencies were due to the type of contingency or the nature of the task. A second problem with this study has to do with the objective social validity measure McLaughlin (1982) used. McLaughlin (1982) does not provide us with enough data to evaluate the reliability or factor structure of the instrument adequately.

Two naturalistic studies comparing the efficacy and social acceptability of group contingencies for improving academic performance were conducted by shapiro and Goldberg (1986, 1987). Each day of the first study (Shapiro \& 
Goldberg, 1986), 53 sixth-grade regular education students were given a list of 10 spelling words randomly selected from their sixth-grade spelling workbook. The students' spelling performances were assessed daily by having them write the words from the spelling list they had received the previous day. The students were given immediate feedback on their performances and then received words for the forthcoming test. The word 1 ists were constructed such that during the entire study, the students were never given the same word twice. Daily spelling test scores were used as a dependent measure. During the six day baseline phase, no group contingency was in effect. Following the baseline phase, an alternating treatments design was used to evaluate the effectiveness of three token reward group contingencies (independent, dependent, and interdependent) to improve spelling performances from baseline levels. Each day prior to the spelling test, the classroom teacher announced to the class what type of contingency was being used for the day and a colored rectangle, corresponding to the type of contingency, was put 
up on the board. During the days the independent group contingency was used, all students scoring 908 or better on the spelling test received five token economy points. For the interdependent group contingency the class' mean spelling test score needed to equal or exceed $90 z$ for all students in the class to receive five token economy points, regardless of their individual scores. On days when the dependent group contingency was being used, after the spelling test, the name of one student in the class was randomly selected. If that student's spelling test score was $90 \%$ or greater, then every student in the class received five token economy points. Following the treatment phase, each student in the class completed a modified version of the CIRP (Witt Elliott, 1983) for each of the group contingencies. In an attempt to improve the internal consistency of the CIRP, Shapiro and Goldberg (1986) eliminated one of the CIRP items and they also (inadvertently) changed the scaling from a six-point Likert to a seven-point Likert scale.

During the data analysis phase of the 
study, based upon mean baseline spelling test scores, Shapiro and Goldberg (1986) blocked the subjects into low $(<70 z)$, middle ( $70 z$ to $84 \%)$, and high (>85\%) groups. Students' performances were basically the same across spelling ability blocks, and indicated no overall differences between the treatment conditions. Shapiro and Goldberg's (1986) basic findings supported previous group contingency research. First, all of the group contingencies led to increases in performance (percent correct spelling words) over baseline levels (Allen et al., 1980; Chadwick \& Day, 1971; Evans \& Oswalt, 1968; Haring Hauck, 1969; Harris Sherman, 1973; Hopkins et al., 1971; Lovitt et al., 1969; Mccarty et al., 1977; McLaughlin, 1981; Meloney \& Hopkins, 1973; sloggett, 1971; Wodarski et al., 1973). Second, Shapiro and Goldberg (1986), like many previous researchers (Allen et al., 1980; Greenwood \& Hops, 1981; Lovitt et al., 1969; McCarthy et al., 1977; McLaughlin, 1981; Sloggett, 1971; Wodarski et al., 1973), did not find one type of group contingency to be more or less effective than another. These researchers, 
however, did find that there were significant differences between the group contingencies with regard to social acceptability. The sixth-grade students judged the independent group contingencies as being significantly more acceptable than either of the interdependent or dependent group contingencies.

Shapiro and Goldberg's (1986) study has contributed to our knowledge of group contingencies and social validation. However, there are some procedural problems with their research that may have effected the results. They may have used a nonrepresentative baseline phase. That is, their baseline phase did not represent all of the conditions of the treatment phase, minus the exposure to the independent variables. During the baseline phase, no token economy system was used. Thus, the use of the token economy represents another independent variable that was not controlled and was confounded with the group contingencies throughout the treatment phase. Because of this confounding, we do not know whether the improvements in spelling performances that 
occurred during the treatment phase were a result of the group contingencies, the token economy, or an interaction of the group contingencies and the token economy.

Another procedural concern of Shapiro and Goldberg's (1986) study concerns their modification of the CIRP (witt Elliott, 1983). They unintentionally reduced the scale from a 6 to a 5-point likert and knowingly eliminated an item because of its reported deviant relations with the other six items. In their second study, Shapiro and Goldberg (1987) replicated the basic procedures of their first study. In the second study, however, the students received two alternating treatments (ATD) phases. In the first phase, the 45 sixth-grade students were assigned to either an interdependent group contingency or a dependent group contingency. Each group of students then received a 16-day treatment procedure where the students were alternatingly placed in large $(n=$ 12) or small ( $n=4)$ group. In the second 16-day ATD phase, the students previously assigned to the interdependent group contingency were placed 
in the dependent group contingency, and vice versa. Then the student received another 16-day ATD procedure where the students were alternatingly placed in a large or small group. Using the CIRP, the students rated the acceptability of each of the treatment conditions at baseline, after the first alternating treatments phase, and after the second alternating treatments phase. The results of this study supported their previous (Shapiro \& Goldberg, 1986) findings. Both of the group contingencies lead to increases in spelling achievement above pretreatment levels. The results of this study also indicated that students' acceptability ratings of the group contingencies significantly increased from pretreatment to posttreatment. Rationale for Additional Group contingency Research

Based on the literature review, there are at least three important issues for group contingency researchers to examine. First, how do students' performance levels effect the success of group contingencies? Future studies 
should more closely control for pretreatment academic ability levels of students. Students with low pretreatment ability levels would probably be able to demonstrate much greater relative spelling performance gains as a result of treatments than would other students. students with high pretreatment spelling ability levels would probably be more subject to "ceiling effects" and would show proportionally smaller spelling performance gains.

A second important question yet to be answered in acceptability research addresses the acceptability-effectiveness hypothesis. Does a student's acceptability ratings of a treatment influence the effectiveness of the treatment? Past research has indicated that independent and interdependent group contingencies are more acceptable than dependent group contingencies (Elliott, Turco, Gresham, in press), however, no general effectiveness differences have been found (Gresham \& Gresham, 1982). Thus far, the studies evaluating the efficacy and social validity of treatments have either been analogue or naturalistic. An empirical link needs to be 
forged between both of these types of studies. This could be accomplished by conducting a study where the efficacy and social validity ratings of an analogue sample are compared to the ratings of a sample of subjects actually experiencing the treatments. Future naturalistic studies should assess the social validity of treatments before and after the students participate in the treatments.

Future research with group contingencies needs to more thoroughly examine the effects of group size and group interactions (Shapiro Goldberg, 1986). Manipulating the size of a group has a number of potential effects on the performances and interactions of the group members. These effects have been a focus of research in cooperative learning theory under the rubric of task structure (Slavin, 1985). Cooperative learning research has much to offer individuals interested in group contingencies. In fact, cooperative learning actually subsumes traditional group contingencies and greatly extends the possible variables that can influence children's behavior. I will now briefly review 
cooperative learning research.

Cooperative Learning strategies

The traditional classroom has a goal structure that emphasizes individualistic competition rather than group cooperation (Slavin, 1985). The competitive goal structures have been criticized for discouraging students from helping one another learn (Johnson \& Johnson, 1975) and for establishing a situation In which low achievers have little chance of success (Slavin, 1977). A perspective on classroom group interventions has been evolving from foundations in social psychology. This perspective emphasizes that students can learn efficiently when they work together (Slavin, 1985). As a result several educational researchers have designed academic management and incentive systems to increase the use of cooperative goal structures (e.g., Johnson \& Johnson, 1975; Sharan Sharan, 1976; Slavin, 1983). These systems collectively have been called cooperative learning strategies and are characterized by having a small heterogeneous group of four to six students working together to 
learn academic material. The reward or incentive structures of cooperative learning groups vary with the particular technique employed. Dimensions of Cooperative Learning Cooperative learning is a multidimensional theory. The theory contains at least 25 dimensions clustered into six categories: (a) philosophy of education, (b) nature of learning, (c) teacher roles, (d) student roles and communication, (e) evaluation, and (f) nature of cooperation (Kagan, 1985). Each of these dimensions is a potential independent variable in cooperative learning research, however, in the proposed study the nature of cooperation category is the most important. For a description of each of the other categories see Kagan, 1985). In cooperative learning theory, the nature of cooperation category has the most in common with the group contingency paradigm. The nature of cooperation category has three dimensions (see Figure 1). The first dimension is the task structure. This refers to how the students are asked to do the work. Students can be asked to work on a task alone (individual task structure) 
or with others (group task structure).

The second dimension in the nature of cooperation is the reward or incentive structure. According to slavin (1983) there are three types of incentive structures. In cooperative incentive structures, two or more students are rewarded based upon their performances as a group. In the competitive incentive structure, two or more students are compared with each other, and those students performing best are rewarded. The individualistic incentive structure is where students are rewarded based upon their own performances.

The last dimension of the nature of cooperation describes the focus of the task or incentive structures. This is the within/between-team dimension. In within-team structures, the task and incentive structures are designed to influence the relationships among the students in the same group. In the between-team structures, rewards and working relationships between different groups are targeted. 
Figure 1

\section{Incentive Structure}

Cooperative Competetive Individualistic
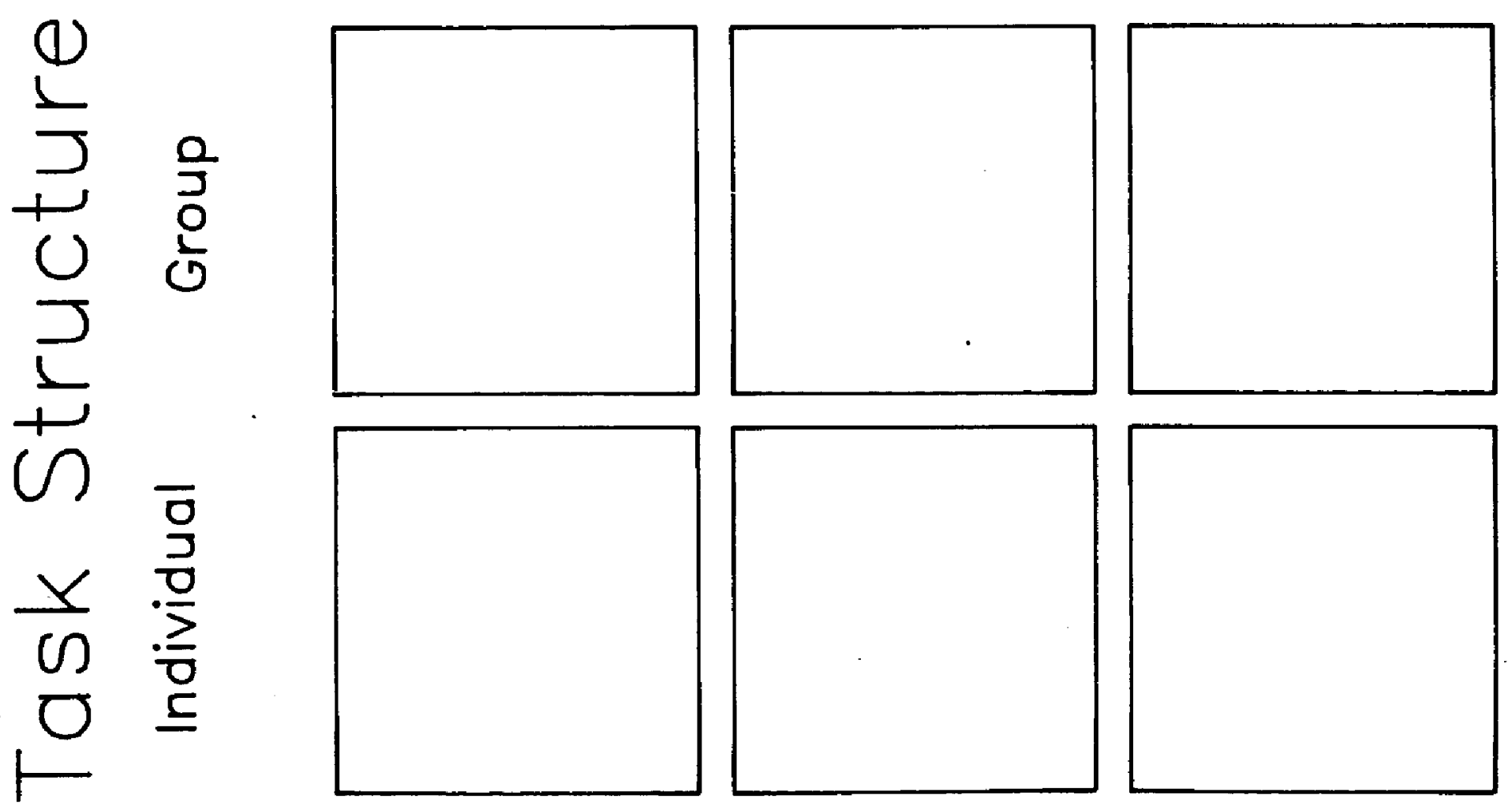


\section{Cooperative Learning Techniques}

Kagan (1985) identified six cooperative learning methods and provided a detailed structural analysis of these methods. A close examination of Kagan's work suggests there are four basic cooperative learning strategies best characterized by student Team Learning, Jigsaw, Learning together, and Group-Investigation. Although each of these basic approaches share the concept of a cooperative goal structure, they exhibit much diversity in terms of task and incentive structure.

Student Team Learning. Two specific interventions, student Teams-Achievement Divisions (STAD) and Teams-Games-Tournament (TGT), both developed by slavin (1980) are representative of this basic approach. In STAD, after a teacher presents a lesson, students work together in small teams (4 to 5 members) in order to master a worksheet on the lesson. Once mastered, each student takes a quiz on the material. The scores students contribute to their teams are based on the degree to which the students have improved over their individual past 
averages. The teams with the highest scores are recognized publicly (e.g., student newspaper) . TGT is similar to STAD, except that students play academic games as representatives of their teams instead of taking quizzes. TGT requires more concern with ability matching across teams and seems to emphasize more individual competition than STAD. Both STAD and TGT employ a group study task structure and provide a group reward for individual learning. Thus, these interventions closely resemble an interdependent group contingency.

Jigsaw. Jigsaw (Aronson, 1978) was one of the first cooperative learning methods. In Jigsaw, each student in a group of five to six students is given some unique information on a topic the entire group is studying. After students study their unique information, they meet with their counterparts from other groups in an "expert group" to discuss the information further. Once the expert groups finish, students return to their learning group to teach their teammates what they have learned. The entire class will eventually take a test for individual 
grades. Thus, although Jigsaw requires cooperation for academic success, it seems to stress the role of individual accountability and in many ways is more like an independent group contingency than an interdependent group contingency.

Learning Together. Perhaps the method that stresses cooperation the most is Learning together as developed by Johnson and Johnson (1975). In this approach to cooperative learning, students work together in small groups to complete a single worksheet. Students receive praise and rewards for successfully completing the worksheet accurately. Thus, this approach stresses group task structure and employs a group product incentive structure.

Group-Investigation. This method was developed by Sharan and Sharan (1976) and is considered by slavin (1985) to be the most complicated cooperative learning method. Specifically, it requires small groups of students to take substantial responsibility for deciding what they will learn, how they will organize themselves to learn it, and how they 
will communicate what they have learned to their teacher and classmates. This method has the least in common with group contingencies and is more aptly characterized as an alternative educational philosophy than a cooperative learning strategy. It stresses task specialization and group product incentive structure. Advantages and Disadvantages of Cooperative Learning Technicues

Advantages. Several reviews documenting the effectiveness of cooperative learning strategies have been published in major journals since 1980 (Johnson, Maruyama, Johnson, Nelson, Skon, 1981; slavin, 1980, 1983). In his 1983 review, slavin identified 46 field experiments in elementary and secondary schools that examined the cooperative learning on student learning in comparison to control groups. In al the studies examined, the cooperative learning intervention lasted a minimum of 2 weeks and most often at least 8 weeks. Slavin (1983) concluded that a favorable effect on student achievement was found in 29 studies, no differences in achievement in 
15, and in 2 studies there was a significant difference favoring the control group. Slavin observed that the most successful methods for increasing student achievement were the ones in which group scores were composed of the sum of individual achievement, or in which each member had a unique task for which he or she could be accountable.

The pervasiveness of the effects of cooperative learning across settings and types of students was also documented in Slavin's (1983) review. He concluded the positive effects of cooperative learning methods on student achievement appeared just as frequently in: elementary and secondary schools, (b) urban, suburban, and rural schools, (c) academic material as diverse as math, language arts, social studies, and reading, (d) with high, average, and low achievers, and (e) with minority students as well as white students.

Several researchers have demonstrated that cooperative learning strategies improved academic performances and/or relationships between mainstreamed and nonmainstreamed handicapped 
students (Armstrong, Johnson, Balow, 1981;

Ballard, Corman, Gottlieb, \&aufman, 1977;

Madden \& Slavin, 1983).

Disadvantages. The educational rationale

for cooperative learning strategies emanated from socialization needs more than achievement needs. Consequently, when one examines cooperative learning strategies from an achievement perspective, several potential disadvantages are apparent. First, there is an inherent danger that the low-achieving students in the heterogeneous teams may have little to contribute and that the high-achieving students may belittle the contributions of the low achievers (slavin, 1985). This problem is averted in the STAD and TGT since they make a group reward contingent on individual learning, however, the possibility for this problem exists in Learning Together and Group-Investigation since reinforcement is contingent on a single group product. Second, the importance of individual education (especially for handicapped children) seems to be negated in some of the cooperative learning approaches. For example, in STAD, TGT, and 
Jigsaw there is no differentiation of learning objectives among students or teams.

Infusing the Group contingency Paradigm with Cooperative tearning Theory

As it is presented in Figure 1, incentive structure in the nature of cooperation category of cooperative learning theory, addresses two of the three types of group contingencies defined by Litow and Pumroy (1975). Cooperative learning theory's cooperative incentive structure is identical to the interdependent group contingency and the individualistic incentive structure is identical to the independent group contingency. Thus, the use of four different terms to describe two different incentive contingencies, is needless duplication of terminology and has probably resulted in unnecessary difficulties in comparing cooperative learning and group contingency studies. One solution to this problem of semantics is to infuse one theory with the other. This would create a new pool of knowledge merging the overlapping perspectives of both theories. on the other hand, the competitive incentive 
structure in the cooperative learning theory and the dependent group contingency are unique contributions of the theories they represent. Incorporating these dimensions into one theory would broaden the perspectives of cooperative learning and group contingencies.

The cooperative learning theory subsumes the group contingency paradigm. Incorporating the group contingency paradigm into the nature of cooperation category of the cooperative learning theory would result in an expanded nature of cooperation categorical model that differentiates five incentive structures (interdependent, competitive, independent, dependent, and no incentive) and two task structures (group and individual) (see Figure 2). Rationale for the Invention of the Present Research Problem

Based on the combined literatures from group contingency and cooperative learning research it was concluded that the variables of task structures and incentive structures influence children's behavior. As noted earlier, there are several issues unresolved in group contingency 
Figure 2

Nature of Cooperation: Full Model

INCENTIVE STRUCTURE

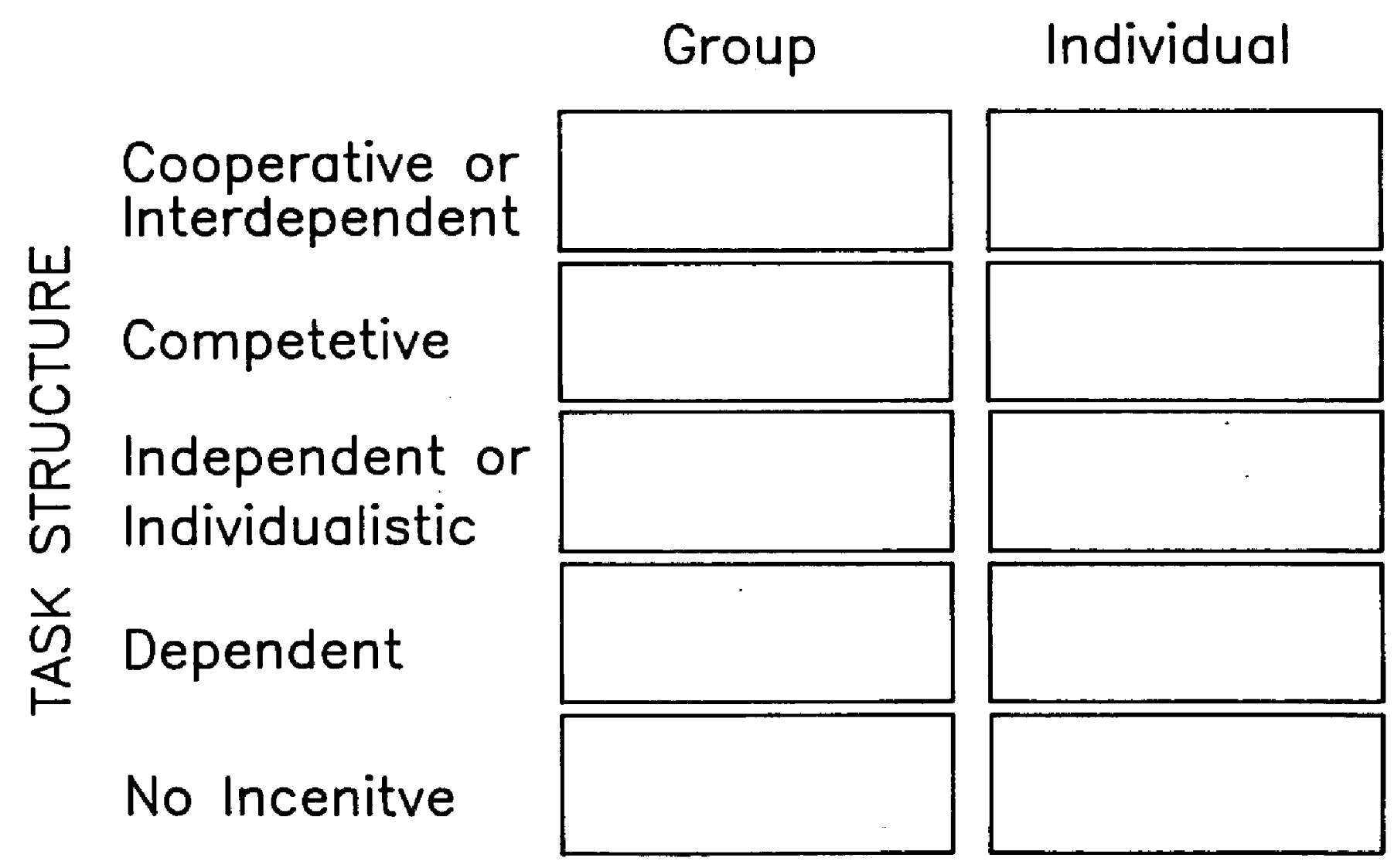


research. First, "How do incentive structures and group make-up affect the outcomes of group contingencies?" The second unanswered question is, "What is the relation between students" ratings of a treatment's acceptability and the treatment's effectiveness?" This question is a major premises of treatment acceptability research. As of yet, this relation has not been tested strongly in a naturalistic study.

In addition, when examining the cooperative learning literature, it is clear that the structure of learning task can influence both academic performances and interpersonal relationships among students. Thus, an investigation of group contingencies was needed that examined the influence of group contingencies on students' academic performances, social status with classmates, and perceptions of the acceptability of group contingency procedures themselves.

\section{Predictions}

Based on the research reviewed, it was predicted that varying the incentive and task structures of the group contingencies would 
significantly influence the spelling achievement of students. Specifically, it was predicted that in the treatment subgroups students' average performances would significantly exceed the average performances of the students in the control group. In addition, it was predicted that students in the four treatments where incentives were available (group task with interdependent incentives, group task with dependent incentives, individual task with interdependent incentives, individual task with dependent incentives) would demonstrate significantly higher average spelling performances than students in the two treatments where no incentives were available (group task with no incentive and individual task with no incentive). It was also predicted that the task structure variable would differentially influence spelling performance and would significantly impact students' social status. Specifically, it was predicted that students working within a group task structure would demonstrate significantly more change in peer-rated social status than students working within the 
independent task structure.

No differences were predicted between the experimental and control groups in students' pretreatment acceptability ratings of the treatments. Additionally, no differences were predicted for the control group between the pretreatment and posttreatment acceptability ratings. It was predicted, however, that the experimental treatment subgroups would have significant changes in their acceptability ratings of the treatments from the pretreatment to posttreatment period. The directions of these changes were predicted to be a result of how successful each group was in attaining incentives and how the task conditions influenced studying. In addition, it was predicted that pretreatment acceptability would correlate significantly with posttreatment spelling achievement as measured by the criterion of percentage of correct words. 
Method

Desian

The present study assessed the spelling achievement of fifth-grade students from two schools (an experimental school and a control school) during a 12-week period with four phases (four weeks of Baseline 1, two weeks of Baseline 2, four weeks of Treatment, and two weeks of a reversal to Baseline 2). Prior to the beginning of the treatment phase and before the beginning of the reversal phase, the students in both groups took a curriculum-based spelling test, the WRAT-R spelling subtest, identified the three students that they liked most and liked least, and rated the acceptability of six interventions designed to improve spelling achievement. The students in the experimental school were assigned randomly to one of six treatment groups which varied according to task structure (group or individual) and incentive structure (interdependent, dependent, no incentive). Each student's WRAT-R Spelling subtest standard score was used initially as a covariate to control for spelling ability levels. The details 
of this design are elaborated on in the section on Procedures.

\section{Subjects}

Fifth-grade students $(\mathrm{N}=74)$ from two senior elementary schools in an urban school district in metropolitan New Orleans served as subjects. Students' participation was voluntary and with prior parent permission. specifically, the initial sample included 39 males and 35 femalesof which 58 were white and 16 were black. During the reversal phase, however, 21 of the original 37 students in the treatment subgroups dropped-out of the study. Experimental Teachers

Three different teachers were hired by the experimenter to conduct this study. The teachers were parent volunteers in the experimental school that were recommended by the principal of the experimental school. Each teacher was paid \$3.50 per hour. The teachers were also paid an additional $\$ 15.00$ per week if treatments were conducted with high integrity. Materials

Four types of materials were necessary to conduct the proposed study. These were spelling 
words to be learned during the treatment, problem-treatment vignettes for testing the pretreatment and posttreatment acceptability of various group contingencles, peer-rated social status rating forms, and video-equipment for documenting the teacher's behavior and treatment conditions. students in the treatment groups learned 12 different 20-item word lists during this study. These word lists were intact spelling units from Level 5 in Basic Goals in spelling (Kottmeyer \& Claus, 1976). This text was in use in the students' classes. The actual word lists used during each phase of the study appears in Appendix A.

During the pretreatment and posttreatment social validity probes, each student received a packet containing seven pages (see Appendix B). The first page was a cover sheet and had a place for the student to write his/her name, gender, race, and had four examples of how to use the Children's Intervention Rating Profile (CIRP) (witt \& Ellott, 1983). The following six pages of the pretest packet all had the same format. Each page had three basic parts: (a) one sentence stating 
that the classroom teacher was going to use a new way of helping the student do better in spelling, (b) four to five sentences describing the task structure (group or individual) and incentive structure (interdependent, dependent, or no incentive) of the spelling intervention, and (c) the CIRP (Witt \& Elliott, 1983) (see Table 2). The CIRP is a seven question, one factor, six-point Likert scale of children's social acceptability ranging from "I Agree" to "I Do Not Agree." The sociometric assessment technique used in this study was developed by Coie, Dodge, and Coppotelli (1982). Within each treatment subgroup, students were asked to list the three students they liked most and the three students they like least. All of the liked least and liked most nominations for each student were summed to yield liked most (LM) and liked least (LL) scores. These scores were then used to calculate a social preference score (SP $=$ IM - LL) and a social impact score (SI $=I M+L L)$. All of the scores were standardized within each treatment group. 
Table 2

Children's Intervention Rating Profile

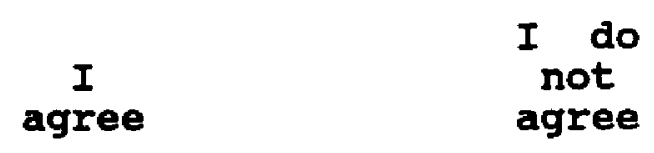

1. The method used to deal with the spelling problem was fair.........

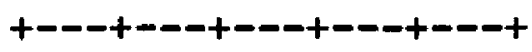

2. This student's teacher was too harsh on him......

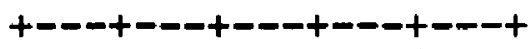

3. The method used to deal with the problem may cause problems with this student's friends

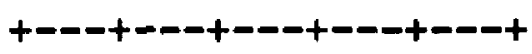

4. There are better ways to handle this student's problem than the one described here

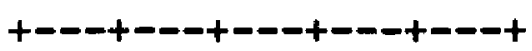

5. The method used by this teacher would be a good one to use with other students.........

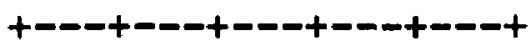

6. I like the method used for this student's problem.

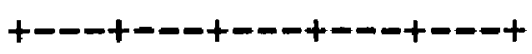

7. I think that the the method used for this problem would help this student do better in school......... 
The integrity of the spelling treatments were checked using a video recorder and a tripod mounted camera. The camera was positioned so that the verbalizations of the experimental teacher and the movements and verbalizations of the students could be recorded.

\section{Procedures}

The procedures used in the present study were designed to allow the collection of data for evaluating the effect of treatments with varying task and incentive structures on students' spelling achievement, acceptability ratings, and sociometric status. There were 14 major procedural steps in the present study.

Selection of the schools. The schools were selected based upon principals' and teachers' interest in participating in an experimental evaluation of methods for improving spelling achievement. One of the schools selected was designated as the experimental treatment school and the other school was lesignated as the control school. The students in the treatment school received pretreatment and posttreatment assessments of social status and treatment acceptability. In 
addition, they received assessments of their spelling achievement before, during, and after the treatment phase. The students in the control school only recelve pretreatment and posttreatment assessments of their spelling achievement, sociometric status, and treatment acceptability.

parent permission. The parents of the students in the experimental group were sent a brief explanation of the spelling program and were asked to sign and return a parental permission form enabling their child to participate in the spelling study (see Appendix C).

Group formation. After parent permission was obtained, students were administered the wide Range Achievement Test - Revised. Each student in the experimental group was then rank ordered based upon his/her WRAT-R spelling subtest standard score. Beginning with the lowest ranked student and proceeding upward through the ranks, each student was assigned systematically to one of the treatment subgroups. This resulted in six heterogeneous treatment subgroups ( $N=5$ to 8 ) with regard to spelling ability (see Figure 3). Once each student's treatment group assignment had 
been made, each of the six treatment groups was labeled numerically. In this way, when the experimental teacher wanted to assemble the members of one of the treatment groups, she was able go to a fifth-grade class and ask for the students in a particular group.

Next, the students within each of the six experimental treatment groups were rank ordered based upon their WRAT-R Spelling subtest scores. Beginning with the lowest ranked student and proceeding upward through the ranks, each student was assigned to one of the treatment subgroups. This resulted in heterogeneous study groups of three to four students within each of the six treatment groups. These smaller groups of students served as study teams and, depending on the particular treatment condition, were instructed to study together (group task structure) or study alone (individual task structure). Each student received a permanent seat and group assignment within the experimental classroom. Each student was instructed to remember what seat he/she was sitting in and to always sit in that seat whenever he/she was brought to the experimental classroom. 
Figure 3

Subgroup Assignments for Subjects
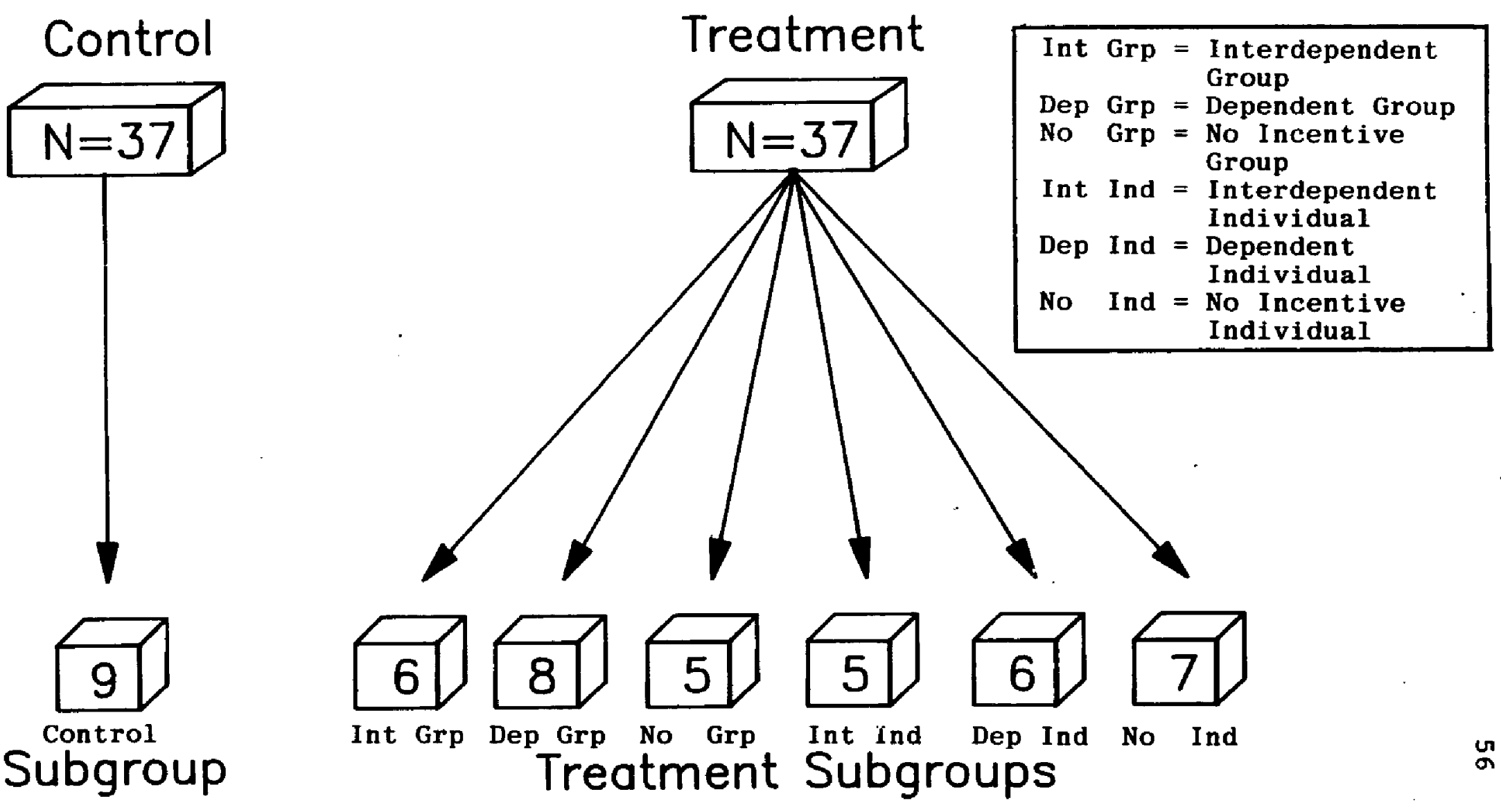
Then the students took a pretest of the 20 gpelling words that would be used the next week.

All six of the experimental treatment groups received the same four experimental phases: (a) a four week Baseline 1 phase, (b) a two week Pretreatment or Baseline 2 phase, (c) a four week Treatment phase, and (d) a two week Posttreatment phase or a reversal to Baseline 2 conditions. In the last three phases, the students were taken from their regular classrooms to an experimental classroom. Only one of the six treatment subgroups were in the experimental classroom at any given time. The students in the experimental group received the treatment on three different days each week for a total of approximately 90 minutes.

To keep cell sizes proportional, a random sample of nine students was selected from the total sample of 37 students in the control group. This control subgroup was used as a comparison group in the statistical analyses (see Figure 3 ). Social acceptability probe. In the regular classroom setting, all of the students in the experimental and control groups received the pretreatment social validity probe. The author 
dispersed the social validity packets and read the instructions, examples, and questions aloud to intact classes of fifth-grade students. The procedure required approximately 10 to 15 minutes of class time to complete.

Each student's responses to the seven CIRP questions was numerically scored (1tem range 1 to 6). Lower numerical values on the CIRP indicate students judged the treatment methods less acceptable.

Sociometric ratings of peers. Each of the students in the treatment groups completed a pretreatment sociometric rating of their peers (see Table 3). The survey asked students to identify the three students in their treatment group that they liked the most and that they liked the least. Pretreatment WRAT-R spelling test. The students in the treatment and control groups were given a group administration of the WRAT-R spelling subtest in the regular classroom.

orientation of experimental group. The first period that students in the experimental group were taken to the experimental classroom was an orientation period. The experimental classroom 
Table 3

\section{Sociometric Ratings of Peers}

Write your name here:

Write the first and last name of the three students in this classroom that you least like:

Now write the first and last name of the three students in this classroom that you like the most: 
teacher called the treatment groups to the experimental classroom one group at a time. At no point in the study was more than one treatment group in the experimental classroom at a time.

Pretesting. The procedures the experimental teacher used for the pretest were used for all of the spelling tests throughout each phase of the study. A pen with green ink was given to each student for use during the test. The teacher said the word to be spelled, used the word in a sentence, and then said the word again. After a 15-second pause, the teacher repeated the process, using the next word in the list. This procedure was repeated until all of the words in the list were presented. Then all of the pens with green ink were put aside and each student was given a pen with red ink. Each student then exchanged his/her test paper with another student. The experimental teacher then had students checked the accuracy of each word by making reference to correction keys. The students put a check mark on the words that were misspelled. The test papers were then returned, so that each student could evaluate his/her own performance. The test papers were then 
collected by the teacher and students returned to their regular academic classroom.

Reinforcers. The reinforcers used in this study were selected by some of the students in the treatment groups. The reinforcers included: (a) school supplies, (b) posters, (c) games, and (d) toys.

Baseline 1 phase. The initial four week baseline phase represented the initial regular classroom conditions. No modifications were made to the regular education spelling curriculum. students' spelling performances during this phase were retrieved from each teacher's grade book at the conclusion of the study.

Baseline 2 phase. For each experimental treatment group, the procedures used during the three phases were basically the same. Three times a week, the following procedure was followed. The experimental teacher turned on the videotape recorder. The teacher then went to one of the participating fifth-grade classrooms and assembled the students in one of the treatment groups. The students were escorted to the experimental classroom by the teacher. Once the students were 
seated, the teacher presented three minutes of group instruction. This instruction focused on understanding how each of the 20 spelling words sounded and was spelled. The experimental teacher pointed out to the students specific phonetic or structural features of the words that may aid the students in learning the proper spellings of the words.

The students then were instructed to study the words for 10 minutes by themselves if they were in one of the individual task structure groups (interdependent incentive structure with an individual task structure, dependent incentive structure with an individual task structure, or no incentive structure with an individual task structure) or in a small group if they were in one of the group task structure treatments (interdependent incentive structure with a group task structure, dependent incentive structure with a group task structure, or no incentive structure with a group task structure). Then a spelling test was given, using the same procedures as in the pretesting section. The teacher then walked the students back to their classrooms and the videotape 
recorder was turned off.

The procedures used on the second day of the week for a given treatment group were the same as those used during the first session. On Friday of each week, the procedures were identical, except that no group instruction or study period was given. On Fridays, students reported to the experimental classroom and took a spelling test over the words that were studied during the week. In addition, the students took a spelling pretest over the words that were to be taught the following week.

Treatment phase. The basic procedures used during the Treatment phase were identical to those used during the Baseline 2 phase. However, at the beginning of each treatment session, the experimental classroom teacher read the appropriate statement from a treatment script (see Appendix D) out loud to the treatment group members. For example, students receiving the group task with interdependent incentives were read the following statement (IV) "For the next 10 minutes you are to study your spelling words with the other students in your group. On Friday, every student in your 
group will take a spelling test. If your group gets an average of 16 of the 20 spelling words correct, everyone in your group will be able to choose a reward." students receiving the group task with dependent incentives were read statement $v$, students receiving the group task with no incentives were read statement VI, and so on.

After the teacher read the treatment instructions, the students in the three treatment subgroups using group task structures were told to work with the other students in their subgroup for the 10 minute study period. Students in three treatment groups using independent task structures were instructed to work by themselves during the 10 minute study period.

On Friday of each week, after the spelling test, the teacher computed the mean number of spelling words correct for the subgroup students in the interdependent incentive treatment. If the group mean was greater than or equal to 16 words correct, every member of the subgroup selected a reward. Students received the rewards prior to leaving the experimental classroom.

The teacher gave each student within each 
dependent incentive subgroup a number ranging from one to three or from one to four, depending upon how many students are in the subgroup. The teacher randomly selected a student in each of the subgroups assigned to a dependent incentive structure. If the randomly selected student got 16 or more words correct on the spelling test, each student in the subgroup was able to select a reward. students received the reward they select before leaving the experimental classroom. students in the no incentive treatment groups were not given any opportunity to select rewards, regardless of their spelling test scores.

Reversal phase or the return to Baseline 2 conditions. At the beginning of the reversal phase, each student in the treatment groups again completed the sociometric rating of their peers (see Table 3). All students in the treatment and control groups then completed the posttreatment social validity probe and the WRAT-R Spelling subtest. The same seven page social validity packet that was used in the pretreatment social validity probe was again administered to intact classes of fifth graders in the experimental and 
control schools, using identical procedures. The instructional procedures used in the experimental classroom during the two-week reversal phase are identical to those that were used in the baseline two phase.

Treatment Integrity assessment. A representative sample of the videotapes of teacher behaviors in the experimental classroom were evaluated by the researcher and one "blinded" rater. The raters evaluated the teacher' $g$ behaviors during each session on the precision in which she presented the instructions to each treatment subgroup, her ability to maintain the time constraints of the treatments, and her omission of additional punishments or rewards in the classroom situation. Variables and Analysis

The present study manipulated four independent variables: (a) task structure (group or individual), (b) incentive structure (interdependent, dependent, or no incentive), (c) group membership (control or treatment), and (d) time period (pretreatment/posttreatment or pretreatment/treatment/posttreatment). The 
influence of these independent variables was tested on five dependent variables: (a) curriculum spelling test scores, (b) mean weekly spelling test scores during each phase of the study, (c) two peer-rated social status measures (social impact and social preference), and (d) students' treatment acceptability ratings. The WRAT-R spelling subtest standard score served as a covariate. The data analysis procedures were designed to evaluate these variables using quasi-experimental group approaches and single-case designs.

Preliminary analyses. The factor structure of the children's Intervention Rating profile (CIRP) (witt \& Elliott, 1983) was evaluated using an orthogonally rotated factor analysis of each student's responses to the seven CIRP questions. An eigen value greater than one criterion was used to identify specific factors. The pretreatment WRAT-R spelling subtest standard score differences between the students in the experimental and control groups were evaluated using a one-way ANOVA.

Yajor analyses. The first two analyses, repeated measures $7 \times 2$ ANOVA's, were used to test 
whether or not there were any pretreatment or posttreatment differences in spelling performances and treatment acceptability ratings between the control group and the six treatment groups. For both ANOVA's the same two independent variables: (a) group membership (control group and six treatment subgroups) and (b) time period (pretreatment and posttreatment) were used. In one ANOVA, the dependent variable was each student's score on the curriculum spelling test. No differences were predicted between the groups on the pretreatment test, however, students in the treatment groups were predicted to score significantly higher than the students in the control group on the posttreatment test.

In the second ANOVA, the dependent variable was each student's treatment acceptability score. It was predicted that the treatment groups collectively and individually would have significantly greater differences between pretreatment and posttreatment measures of acceptability than the sample of students in the control school.

The collective differences between the 
treatment and control groups was evaluated using a $2 \times 7$ ANOVA. The individual differences between the pretreatment and posttreatment acceptability ratings of students was evaluated in a series of one-way ANOVA's employing the Bonferonni correction formula.

A $3 \times 2 \times 2$ ANOVA was used to test for students' pretreatment-posttreatment differences in social acceptability as a function of task structure and incentive structure. The dependent variable was each student's treatment acceptability rating. students in the treatment subgroups were predicted to have significant changes in their acceptability ratings of the treatments from the pretreatment to posttreatment period. The directions of these changes were predicted to be a result of how successful each group was in attaining incentives and the task conditions. Next, a $3 \times 2 \times 2$ MANCOVA was used to test the effects of incentive and task structure over time on a student's social impact and social preference. students working within a group task structure were predicted to demonstrate significantly more change in peer-rated social 
status than students working within the independent task structure. The covariate for this analyses was WRAT-R Spelling subtest score.

A 3 X 3 X 2 ANCOVA analyses was used to test for students' mean differences in weekly spelling achievement as a function of task structure, incentive structure, and time period. The covariate for this analysis was each student's WRAT-R Spelling subtest score. The dependent variable was each student's mean weekly spelling test score for each of the three time periods. It was predicted that students in treatment groups receiving incentives would have significantly higher treatment phase spelling acheivement than student in the no incentive groups. Students in treatment groups where a group task structure was used were also predicted to have mean treatment spelling achievement scores that were significantly higher than students in the individual task structure groups.

The final major analysis was conducted to determine whether there was a significant treatment acceptability and treatment effectiveness relation. The variables for this correlational 
analysis were students' treatment acceptability ratings and their mean spelling achievement scores. 


\section{Results}

Five sets of analyses were designed to test the major predictions of this study. Briefly, these analyses tested the factor structure of the CIRP and achievement comparisons of the sample, the pretreatment-posttreatment differences in acceptability ratings of the treatment methods, the pretreatment-posttreatment differences in effectiveness of the treatment methods on spelling performances, the relation between rated acceptability and effectiveness of the treatments, and the pretreatment-posttreatment differences in peer social nominations among subjects in each treatment method. An examination of each of these analyses follows. Preliminary Analyses

Spelling achievement comparisons. The results of the one-way ANOVA indicated that the average pretreatment WRAT-R Spelling subtest standard scores for the experimental $(H=103.50)$ and control $(X=94.92)$ schools did not differ significantly $(\mathrm{E}(1,73)=3.7098, \mathrm{Q}<.06)$. Therefore, the WRAT-R spelling was not used as a covarlate in the subsequent analyses comparing 
the experimental and control schools.

A 2 × 3 ANOVA was conducted testing the

differences in pretreatment WRAT-R spelling

standard scores among students from the

experimental school in each of the six Task $x$

Incentive subgroups. The means and standard

deviations of the students' WRAT-R spelling

scores appear in Table 4. The results of the

ANOVA indicated that there were no significant

pretreatment differences between any of the six

treatment subgroups in spelling achievement (see

Table 5).

Factor analysis of the CIRP. The results of two unrotated factor analyses of the Children's Intervention Rating Profile (CIRP) indicated that at both pretreatment and posttreatment, the CIRP was a one factor scale (see Table 6). Because the factor analysis of the CIRP consistently yielded one factor, each student's total CIRP score was considered a univariate dependent variable for subsequent analyses. Reliability of the CIRP. The test-retest reliability and internal consistency of the 
Table 4

Means and Standard Deviations of the wide Range

Achievement Test - Revised (WRAT-R) Spelling

a

standard scores

\begin{tabular}{|c|c|c|c|}
\hline \multirow[b]{2}{*}{ Source } & & \multicolumn{2}{|c|}{ Treatment Phase } \\
\hline & & Pre & Post \\
\hline $\begin{array}{l}\text { Experimental School } \\
\text { Total }\end{array}$ & $\underset{\mathrm{N}}{\mathrm{M}} \mathrm{SD}$ & $\begin{array}{l}103.50 \\
12.17 \\
37\end{array}$ & $\begin{array}{l}107.53 \\
10.63 \\
37\end{array}$ \\
\hline Interdependent Group & $\underset{\mathbf{N}}{\mathbf{M}} \mathbf{S D}$ & $\begin{array}{c}107.33 \\
11.1 \\
6\end{array}$ & $\begin{array}{c}110.83 \\
13.01 \\
6\end{array}$ \\
\hline Dependent Group & $\underset{\mathbf{N}}{\mathbf{M D}}$ & $\begin{array}{c}104.75 \\
8.68\end{array}$ & $\begin{array}{l}109.88 \\
12.23 \\
8\end{array}$ \\
\hline No Incentive Group & $\mathbf{N}_{\mathbf{S D}}^{\mathbf{M}}$ & $\begin{array}{c}104.60 \\
7.30 \\
5\end{array}$ & $\begin{array}{c}107.80 \\
6.65 \\
5\end{array}$ \\
\hline $\begin{array}{l}\text { Interdependent } \\
\text { Individual }\end{array}$ & $\underset{\mathbf{N}}{\mathbf{M}} \mathbf{S D}$ & $\begin{array}{c}101.40 \\
9.61 \\
5\end{array}$ & $\begin{array}{c}103.20 \\
9.65 \\
5\end{array}$ \\
\hline $\begin{array}{l}\text { Dependent } \\
\text { Individual }\end{array}$ & $\underset{N}{\mathbf{N}}$ SD & $\begin{array}{l}98.00 \\
22.47 \\
6\end{array}$ & $\begin{array}{c}107.33 \\
9.14 \\
6\end{array}$ \\
\hline $\begin{array}{l}\text { No Incentive } \\
\text { Individual }\end{array}$ & $\mathrm{ND}_{\mathrm{N}}^{\mathrm{M}}$ & $\begin{array}{l}97.78 \\
21.83 \\
7\end{array}$ & $\begin{array}{l}105.37 \\
12.42 \\
7\end{array}$ \\
\hline
\end{tabular}


Table 4 (continued)

\begin{tabular}{lccc}
\hline & & Treatment Phase \\
Source & & Pre & Post \\
\hline Control school & & & \\
Total & M & 94.92 & 96.05 \\
& SD & 17.22 & 18.68 \\
Control School & N & 37 & 37 \\
Subgroup & & & \\
& M & 105.78 & 104.89 \\
& SD & 17.37 & 19.74 \\
& N & 9 & 9
\end{tabular}

a b

Mean $=100$, Standard Deviation $=15$

no pretreatment differences between the schools

c

$(F(1,73)=3.7098,2<.06)$

at posttreatment the experimental school is significantly greater than the control school

$(F(1,73)=9.6415, \quad \mathrm{D}<.0026)$ 
Table 5

ANOVA Source Table for Wide Range Achievement Test - Reviged (WRAT-R) as the Dependent Variable with Group and Time as the Independent Variables

Source

ss

df

MS

F

p

Between Subjects

$\begin{array}{llllll}\text { Group } & 3769.36 & 1 & 3769.36 & 9.43 & .003\end{array}$

Within subjects

Time

$249.71 \quad 1$

$249.71 \quad 4.92 \quad .030$

Group $\mathrm{x}$ Time

78.35

1

78.35

$1.54 \quad .218$ 
Table 6

Unrotated Factor Analysis of the children's

Intervention Rating Profile (CIRP)

Pretreatment

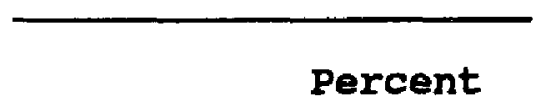

Item

Eigenvalue Variance
Posttreatment

Percent

Eigenvalue Variance
1. Method fair?

2. Teacher too harsh?

3. Problems with peers?

4. Are there better ways?

5. Use with other students?

6. Do you like the method?

7. Do better in school?
$3.3022 \quad 47.2$

$.8725 \quad 12.5$

$.8372 \quad 12.0$

$.7219 \quad 10.3$

$.4965 \quad 7.1$

$.4303 \quad 6.1$

$.3393 \quad 4.8$
3.5278

50.4

$.9523 \quad 13.6$

$.7762 \quad 11.1$

.6800

9.7

.4315

6.2

.3440

4.9

.2881

$4 \cdot 1$ 
CIRP for this fifth-grade sample also were

evaluated. The test-retest correlational analyses of the CIRP indicated generally low reliability scores from pretreatment to posttreatment ( $x$ ranges from -.02 to .74) (see Table 7). Although the reliability coefficients are relative low, the correlations do show a consistent trend. The most stable reliability scores are found in the analogue control group. The lowest reliability coefficients were found in the treatment subgroups where the students' had some actual exposure to the treatment method they rated.

Cronbach's (1951) coefficient alpha was also computed to estimate the internal consistency of the CIRP at both pretreatment and posttreatment. The results of these analyses indicated that the pretreatment coefficient alpha of the CIRP was . 80 and the posttreatment coefficient alpha was .82 . Thus, internal consistency of the CIRP was fairly high and stable across the treatment procedures and time.

Treatment integrity. The results of the treatment integrity assessment indicated that the experimental teachers did present the instructions 
Table 7

Test-Retest Reliability of the Children's Intervention Rating

Profile

Group

Correlation

Experimental School Analogue Evaluation

Group Task

Interdependent

Dependent

No Incentive

Individual Task

Interdependent

Dependent

No Incentive

Experimental School Naturalistic Evaluation

Group Task

Interdependent

Dependent

No Incentive

.12

.14

$-.33$

Individual Task

Interdependent

Dependent

.74

No Incentive

$-.02$

.08

Total Experimental Sample

$.57 *$

Control School Analogue Evaluation

Group Task

Interdependent

Dependent

No Incentive

Individual Task

Interdependent

Dependent

No Incentive

.11

$.37 *$

$.30 *$

.12

$.27 *$

$.42 * \star$

Total Control sample

.15

$\star \mathrm{p}<.05$

$\star \star \mathrm{p}<.01$ 
to the treatment subgroups as prescribed and did not add any additional rewards or punishments. However, the temporal integrity of the treatments did vary in this study. As Figure 4 illustrates, the experimental teachers deviated from the prescribed 180 seconds of instruction (range 53 to 323 seconds) and 600 seconds of study time (range 470 to 671 ).

Maior Analyses and Tests of Predictions Acceptab11ity ratings: Treatment subgroups versus analogue control group. A $2 \times 6 \times 7$ repeated measures ANOVA was used to determine whether the acceptability ratings of students in an analogue control condition differed from students receiving actual exposures to one of the six treatments. In this analysis, the dependent variable, total CIRP scores, was evaluated across each level of three independent variables: time (two levels: pretreatment and posttreatment), treatment method (six levels: interdependent group, dependent group, no incentive group, interdependent individual, dependent individual, and no incentive individual), treatment subgroup (seven levels: interdependent incentive structure with a group 
Figure 4 Instruction and Study Time Integrity
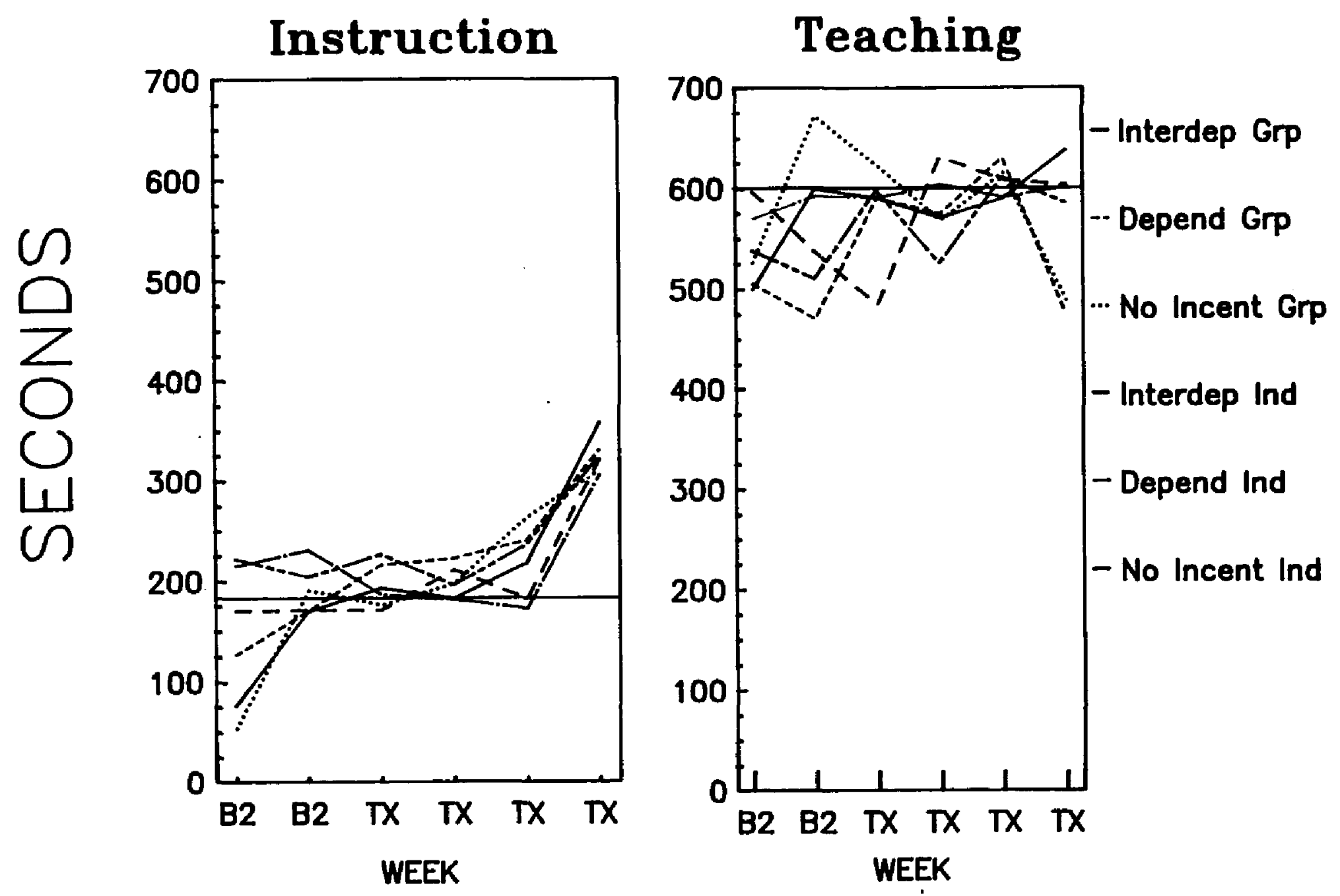
task structure, dependent incentive structure with a group task structure, no incentive structure with a group task structure, interdependent incentive structure with an individual task structure, dependent incentive structure with an individual task structure, no incentive structure with an individual task structure, and no treatment control). The means and standard deviations of the CIRP acceptability ratings of all of the treatment methods by each of the treatment subgroups is presented in Table 8 . The results of the ANOVA indicated significant main and interaction effects for Method $(E(5,36)=6.58, \underline{p}<.0001)$, Time ( $F$ $(1,41)=39.52, \mathcal{R}<.0001)$, Time $X$ Method $(F$ $(5,36)=4.27, \underline{p}<.005)$, and Time $x$ Treatment Subgroup $(E(6,41)=2.42, \underline{2}<.042)$ (see Table 9).

Comparisons of the mean CIRP pretreatment and posttreatment ratings indicated that the acceptability ratings of the students decreased across time. Follow-up scheffe's analysis (alpha = $.05)$ of the significant main effect for method indicated that the interdependent group method was significantly more acceptable than the dependent 
Table 8

Rretreatment and Posttreatment children's Interyention Rating Proftle (CIRP) scores for Each of the seyen Treatment subarouns

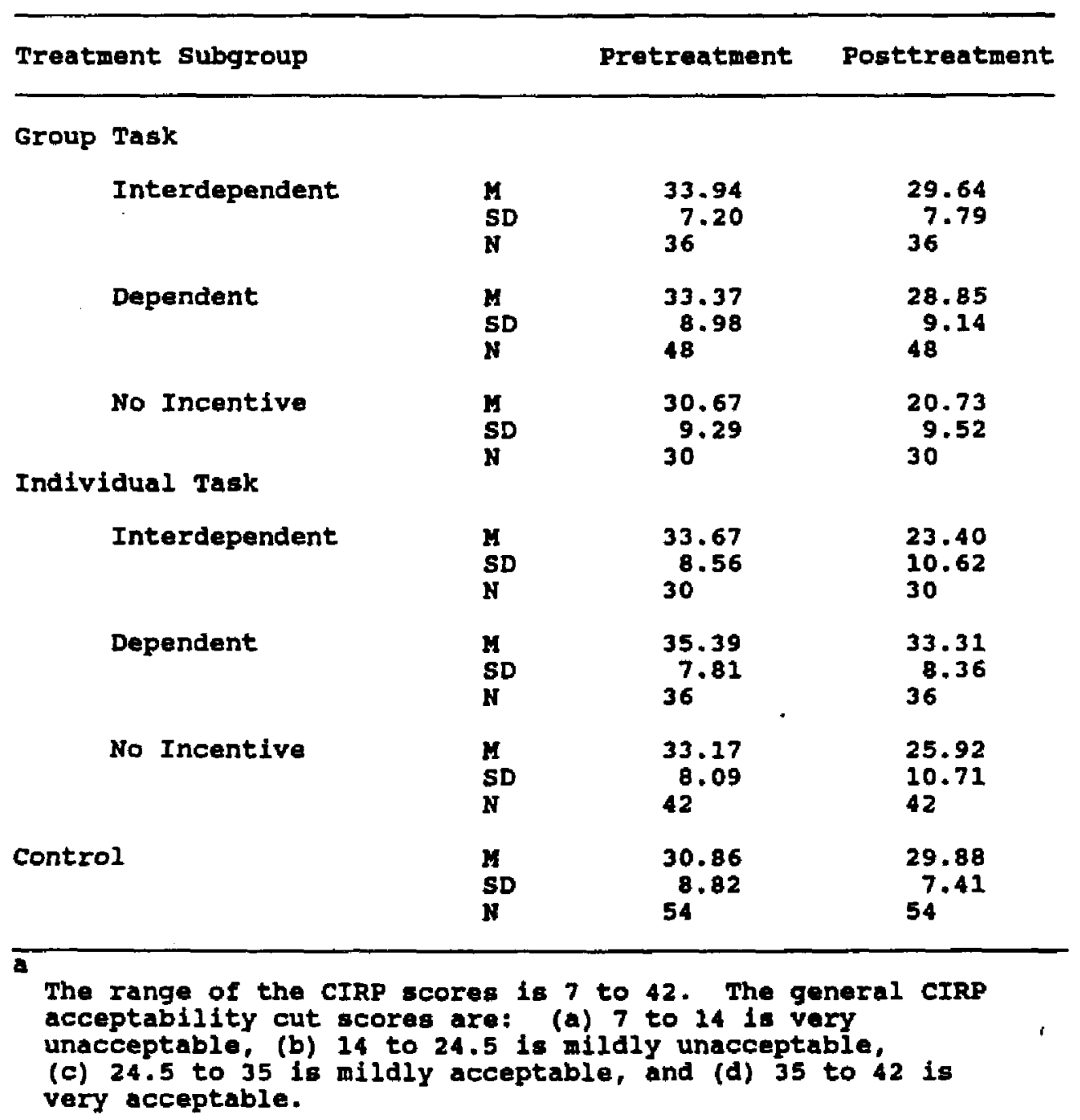




\begin{tabular}{|c|c|c|c|c|}
\hline source & df & MS & $\mathbf{F}$ & $\mathbf{p}$ \\
\hline \multicolumn{5}{|l|}{ Between Subjects } \\
\hline Treatment Subgroup & 6 & 647.80 & 2.15 & .059 \\
\hline \multicolumn{5}{|l|}{ within subjects } \\
\hline 4903.96 & 1 & 4903.96 & 46.56 & .0001 \\
\hline Method & 5 & & 7.89 & .0001 \\
\hline Time $\mathrm{x}$ Method & 5 & & 5.01 & .0011 \\
\hline Time $x$ Treatment subgroup & 6 & 318.37 & 3.02 & .012 \\
\hline Method X Treatment Subgroup & 30 & & 1.00 & .514 \\
\hline Time $X$ Method $X$ Treatment Subgroup & 30 & & 1.26 & .167 \\
\hline
\end{tabular}




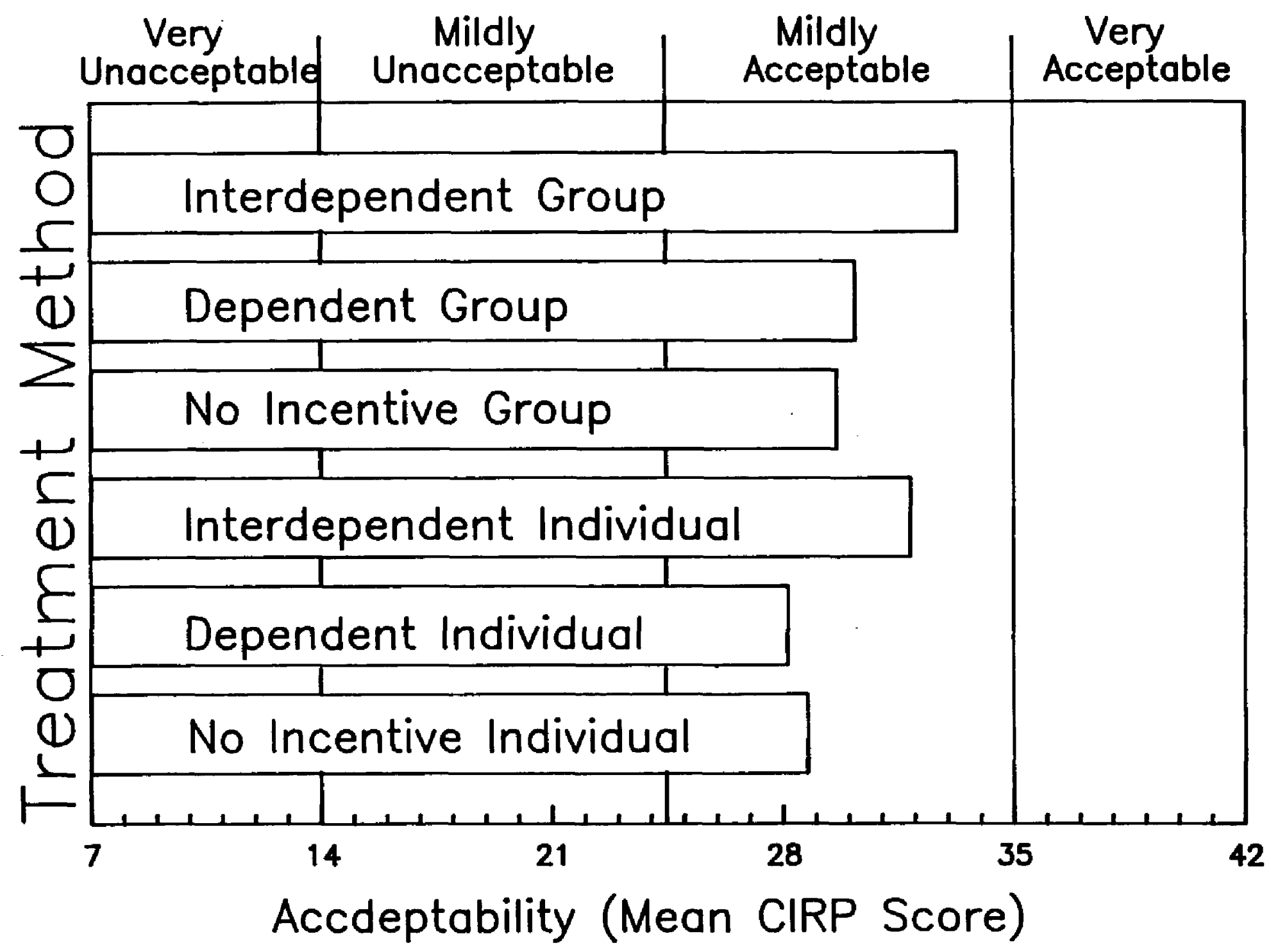


Table 10

Children's Intervention Rating Profile (CIRP) scores for Fach of the Treatment Methods

Treatment Method

Group Task

Interdependent Incentive

$\begin{array}{lr}\text { M } & 33.31 \\ \text { SD } & 8.04\end{array}$

Dependent Incentive

$M \quad 30.22$

No Incentive

M 29.66

SD $\quad 9.55$

Individual Task

Interdependent Incentive

$\begin{array}{lr}\text { M } & 31.88 \\ \text { SD } & 9.47\end{array}$

Dependent Incenitve

M $\quad 28.17$

SD $\quad 10.64$

No Incentive

$\begin{array}{lr}M & 28.77 \\ \text { SD } & 8.47\end{array}$

a

The range of the CIRP scores is 7 to 42 . The general CIRP acceptability cutting scores are: (a) 7 to 14 is very unacceptable, (b) 14 to 24.5 is mildly unacceptable, (c) 24.5 to 35 is mildiy acceptable, and (d) 35 to 42 is very acceptable.

n $=92$ for each group 
group, dependent individual, and no incentive individual methods (see Figure 5 and Table 10).

Post hoc joint effect analyses (see Appendix E) (Marascuilo \& Levin, 1970) (alpha $=.05$ ) indicated that the acceptability ratings for the pretreatment dependent group, posttreatment dependent group, and posttreatment interdependent group treatment methods were responsible for the significant Time $x$ Method interaction. In order to answer one of the three major predictions about students' treatment acceptability scores, a series of one-way ANOVA's were conducted testing the differences between the pretreatment and posttreatment acceptability ratings of each of the seven subgroups. The results indicated that, with the exception of the dependent individual subgroup and the control group, all of the treatment subgroups had significant decreases in acceptability ratings across time (see Table 11). Post hoc joint effect analysis also indicated that no simple combination of time and treatment subgroups was solely responsible for the significant Time $x$ Group interaction. 
Table 11

Source Table tor the Results of a series of one-way ANova's Examining Pretreatment to Posttreatment Acceptability Rating Differences Between the students in the seven Treatment subqroups

\begin{tabular}{lccc}
\hline Source & df & $F$ & $p$ \\
\hline Interdependent Group & 1,70 & 5.72 & .0176 \\
Dependent Group & 1,70 & 5.97 & .0165 \\
No Incentive Group & 1,58 & 16.72 & .0001 \\
Interdependent Individual & 1,58 & 16.98 & .0002 \\
Dependent Individual & 1,70 & 1.93 & .2784 \\
No Incentive Individual & 1,106 & 15.71 & .0002 \\
Control & 1,112 & .02 & .8986 \\
\hline
\end{tabular}


Treatment acceptability under varying

incentive and task structure. A $2 \times 2 \times 3 \times 6$ repeated measures ANOVA was used to evaluate whether varying incentive and task structures of group contingencies influenced students' treatment acceptability ratings of the six treatment methods at two points in time. The cell means and standard deviations relevant to this analysis are displayed in Table 12. The results of the ANOVA indicated significant main and interactions effects for: Treatment Method $(\mathrm{F}(5,29)=10.63, \mathrm{Q}<.0001)$, Incentive structure $(E(2,33)=3.69, \underline{D}<.0361)$, Time X Incentive structure $(E(2,33)=3.31, \mathfrak{p}<$ $.0491)$ and Time $X$ Treatment Method $(E(5,29)=$ 4.74, $\mathbf{p}<.0031$ ). The complete source table for this analysis appears as Table 13 . Post hoc Scheffe's analysis (alpha $=.05$ ) of the significant main effect for the incentive structures indicated that, although students in all of the incentive structure subgroups rated the treatment methods as being acceptable, the students in the interdependent incentive structure rated treatment methods as being significantly more acceptable than the students in 
Table 12

Pretreatment and Postreatment chlidren's Intervention Rating Profile (CIRP) Scores for Each of the Incentive structures:

\begin{tabular}{lccc}
\hline Incentive structures & & Pretreatment & Posttreatment \\
\hline Interdependent & M & 34.00 & 28.65 \\
\multicolumn{1}{c}{ SD } & & 8.17 & 9.42 \\
Dependent & SD & 29.32 & 26.11 \\
& S & 10.42 & 10.44 \\
No Incentive & SD & 30.87 & 26.99 \\
& & 7.99 & 9.14 \\
\hline
\end{tabular}

a

The range of the CIRP scores is 7 to 42 . The general CIRP acceptability cut scores are: (a) 7 to 14 is very unacceptable, (b) 14 to 24.5 is mildly unacceptable, (c) 24.5 to 35 is mildly acceptable, and (d) 35 to 42 is very acceptable.

b

$n=148$ for each group 
Table 13

Source Table for a Repeated Measures ANova Examining Pretreatment and Posttreatment Acceptability Ratings of students in sach Incentive structure and Task Structure

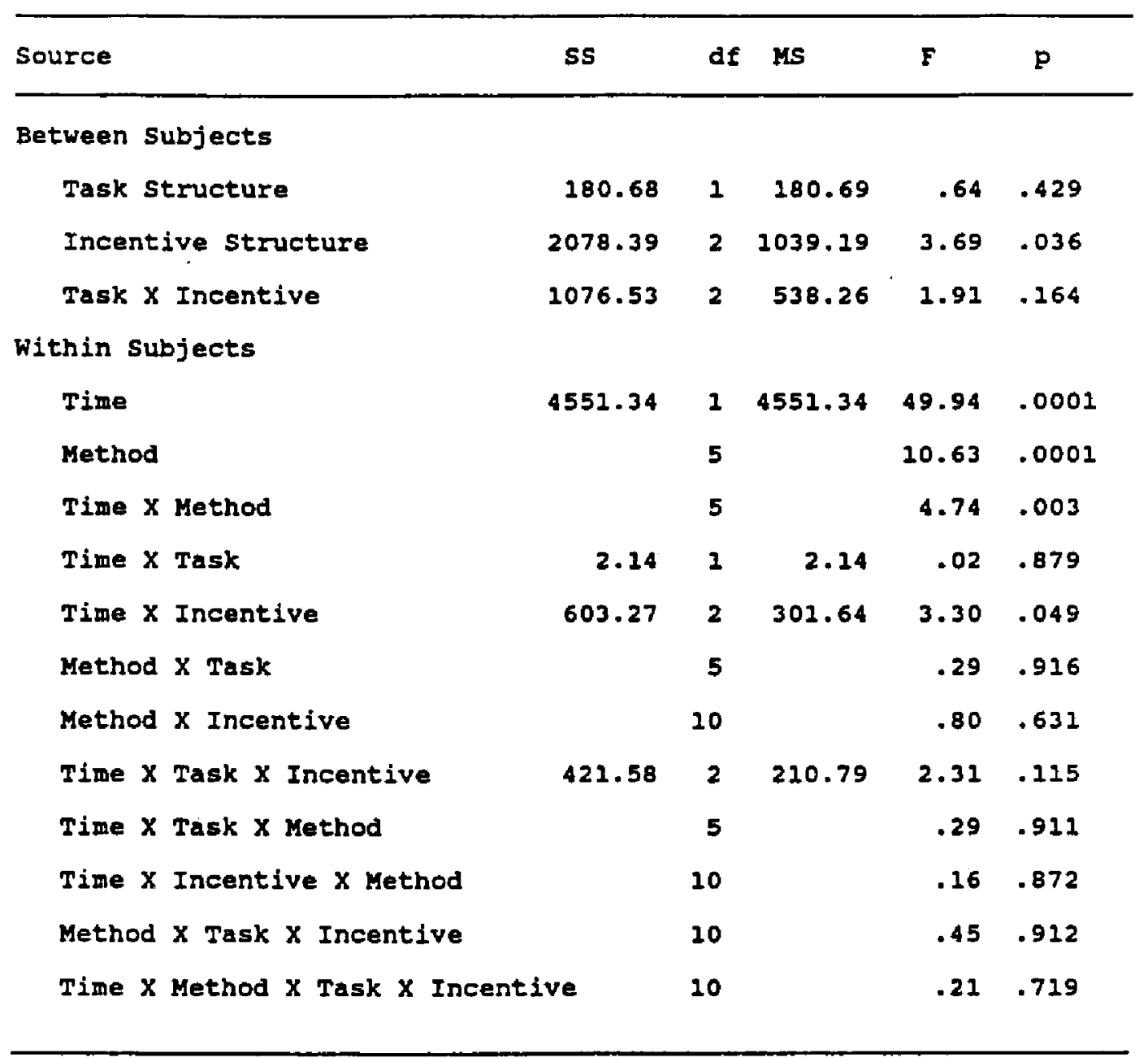


the dependent or no incentive subgroups. Post hoc

Scheffe's analysis (alpha $=.05$ ) of the significant main effect for the incentive structures indicated that, although students in all of the incentive structure groups rated the treatment methods as being acceptable, the students in the interdependent incentive structure subgroup rated treatment methods as being significantly more acceptable than the students in the dependent or no incentive subgroups. Follow-up scheffe's analysis (alpha $=.05$ ) of the significant main effect for treatment method indicated that the interdependent group treatment method was significantly more acceptable than the dependent individual, and no incentive individual treatment methods. Post hoc joint effect analyses (alpha $=.05$ ) indicated that the pretreatment acceptability ratings of students in the dependent incentive method were responsible for the significant Time $x$ Incentive interaction. Post hoc joint effect analysis also indicated that at pretreatment the dependent group and interdependent individual treatment methods were rated as being more 
acceptable than the acceptability ratings of the other treatment methods. Also, the posttreatment acceptability ratings of the dependent group treatment method were significantly lower than the acceptability ratings of the other treatment methods.

Effectiveness of Treatments for Increasing Spelling Achievement

The effectiveness of the treatment methods for improving spelling were evaluated based on group and single-case analyses of three dependent variables: (a) spelling standard scores from the wide Range Achievement Test - Revised, (b) curriculum test spelling scores, and (c) weekly unit spelling tests. The inclusion of the spelling data from the reversal phase was not possible because of the high levels of student attrition from the treatment phase to the reversal phase. Although student attrition was evident in all of the treatment subgroups, the attrition was highest in the subgroups using the group task structures. The interdependent group and the dependent group had $100 \%$ subject drop-out from the treatment phase to the reversal phase and $40 \%$ drop-out in the 
incentive group. Lower attrition rates were observed in the interdependent individual (40\%), dependent individual (298), and no incentive individual (11t).

WRAT-R Spelling. students' performances on the wide Range Achievement Test - Revised (WRAT-R) Spelling subtest were compared in a 2 X 2 repeated measures ANOVA to determine if there were any significant pretreatment to posttreatment changes in spelling performances between the experimental and control schools. The results indicated significant main effects for time $(E(1,73)=4.91$, $\mathrm{p}<.031$, and group $(\mathrm{F}(1,73)=9.43, \underline{\mathrm{p}}<.0031)$. As noted earlier in Table 4, the WRAT-R Spelling scores of both the experimental and control groups increased (average of 4 standard score points for the experimental group and slightly less than 2 standard score points for the control group) over time.

Spelling standard scores from the WRAT-R were also used to evaluate the affect of the incentive and task structures on spelling achievement. In a $2 \times 2$ repeated measures ANCOVA, where each students' pretreatment WRAT-R Spelling subtest 
score was used as a covariate and the posttreatment WRAT-R Spelling subtest standard score was the dependent variable. The results of this ANCOVA indicated no significant main or interaction effects for incentive or task variables.

Curriculum spelling. The curriculum spelling test scores were first used to evaluate pretreatment to posttreatment changes in spelling achievement in each of the seven treatment subgroups. Table 14 documents the pretreatment and posttreatment means and standard deviations for each treatment subgroup. A $2 \times 7$ repeated measures ANOVA resulted in only a significant main effect for time $(E(1,67)=39.91, \mathrm{p}<.0001)$ (see Table 15). The mean curriculum test scores increased ( $\underline{M}$ $=+2.58$ words) from pretreatment to posttreatment in all seven treatment subgroups. The curriculum test score increases of all of the treatment subgroups, except the interdependent subgroup, exceeded the test score increases of the control subgroup. The interdependent subgroup, however, had the highest pretreatment curriculum test scores, so an increase in performance was more difficult for this subgroup. 
Table 14

Pretreatment and Posttreatment curciculum spelling rest

Scores for Each of the seven Treatment Subgroups

\begin{tabular}{|c|c|c|c|c|}
\hline Treatment Group & & Pre & Post & Change \\
\hline \multicolumn{5}{|l|}{ Group Task } \\
\hline Interdependent & $\begin{array}{l}\mathbf{M} \\
\mathbf{S D} \\
\mathbf{N}\end{array}$ & $\begin{array}{l}8.00 \\
5.17 \\
6\end{array}$ & $\begin{array}{l}9.17 \\
4.53 \\
6\end{array}$ & +1.17 \\
\hline Dependent & $\begin{array}{l}M \\
\mathrm{SD}\end{array}$ & $\begin{array}{l}5.12 \\
3.14 \\
8\end{array}$ & $\begin{array}{l}8.87 \\
4.19 \\
8\end{array}$ & +3.75 \\
\hline No Incentive & $\begin{array}{l}M \\
S D \\
N\end{array}$ & $\begin{array}{l}4.60 \\
2.70 \\
5\end{array}$ & $\begin{array}{l}7.40 \\
1.51 \\
5\end{array}$ & +2.80 \\
\hline \multicolumn{5}{|l|}{ Individual Task } \\
\hline Interdependent & $\begin{array}{l}M \\
S D\end{array}$ & $\begin{array}{l}4.80 \\
2.39 \\
5\end{array}$ & $\begin{array}{l}6.60 \\
4.67 \\
5\end{array}$ & +2.80 \\
\hline Dependent & $\begin{array}{l}M \\
\mathbf{S D} \\
\mathbf{N}\end{array}$ & $\begin{array}{l}5.50 \\
3.39 \\
6\end{array}$ & $\begin{array}{l}9.50 \\
2.25 \\
6\end{array}$ & +4.00 \\
\hline No Incentive & $\begin{array}{l}\mathbf{H} \\
\mathbf{S D} \\
\mathbf{N}\end{array}$ & $\begin{array}{l}7.33 \\
3.74 \\
7\end{array}$ & $\begin{array}{l}9.44 \\
3.17 \\
7\end{array}$ & +2.11 \\
\hline Control & $\begin{array}{l}M \\
S D \\
N\end{array}$ & $\begin{array}{r}5.94 \\
4.23 \\
10\end{array}$ & $\begin{array}{l}7.37 \\
5.05 \\
10\end{array}$ & +1.43 \\
\hline
\end{tabular}


Table 15

Source Table for a Repented Measures ANova Examining the Pretreatment and Posttreatment Curciculum Spelling Test scores

for Each of the Seven Treatment Subgrougs

\begin{tabular}{llllll}
\hline Source & Ss & df & MS & F & p \\
\hline $\begin{array}{l}\text { Between subjects } \\
\text { Treatment subgroup }\end{array}$ & 102.87 & 6 & 17.14 & .55 & .768 \\
$\begin{array}{l}\text { Within Subjects } \\
\text { Time } \\
\begin{array}{c}\text { Time X Treatment } \\
\text { Subgroup }\end{array}\end{array}$ & 145.75 & 1 & 145.75 & 39.91 & .000 \\
\hline
\end{tabular}


A $2 \times 2 \times 3$ repeated measures ANovA was conducted with the $\mathbf{s i x}$ subgroups actually receiving extra spelling instruction to evaluate the affect of a students' incentive structure and task structure on pretreatment to posttreatment changes in curriculum spelling test scores as a result of a student's incentive or task structure. The result of this analysis again only indicated a significant main effect for time $(E(1,36)=21.04, \mathfrak{p}<$ $.0001)$

Weekly unit spelling. The weekly pretest, posttest, and regular classroom unit spelling test scores were evaluated via group and single-case analyses. A $2 \times 3 \times 2 \times 2$ MANOVA was used to evaluate the pretest to posttest spelling performances of students in the six treatment groups from the baseline to treatment phase. The results of this MANOVA indicated no significant main or interaction effects.

Figures 6 to 11 illustrate the pretest, posttest, and class unit spelling scores for each student in the six treatment subgroups. visual inspection of these figures reveals a consistent increase in unit spelling scores from pretest to 
Figure 6

Weekly Spelling Performances for the Interdependent group treatment Sub group.

Sub ject 1

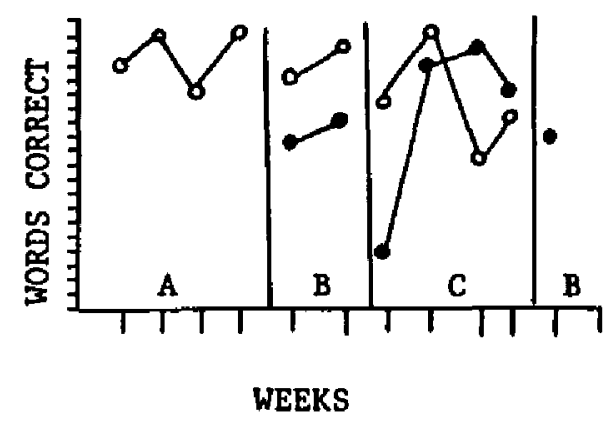

Subject 3

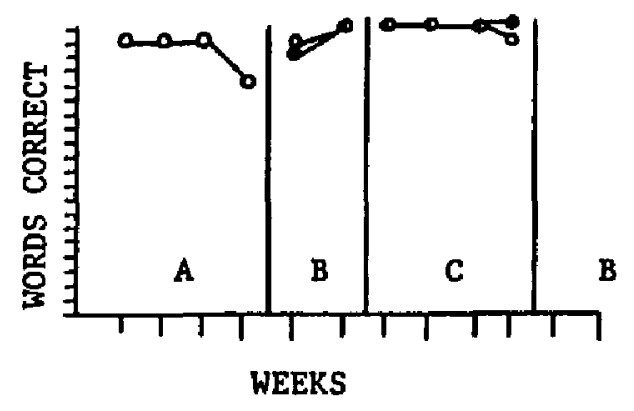

Subject 5

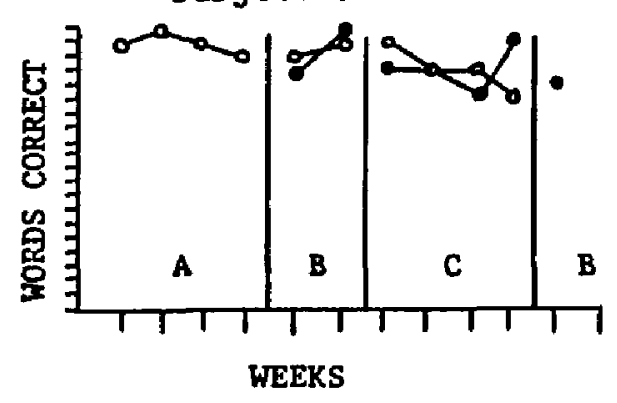

Subject 2

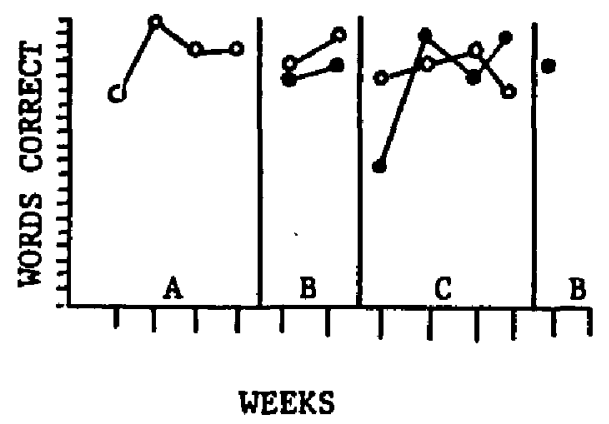

Sub ject 4

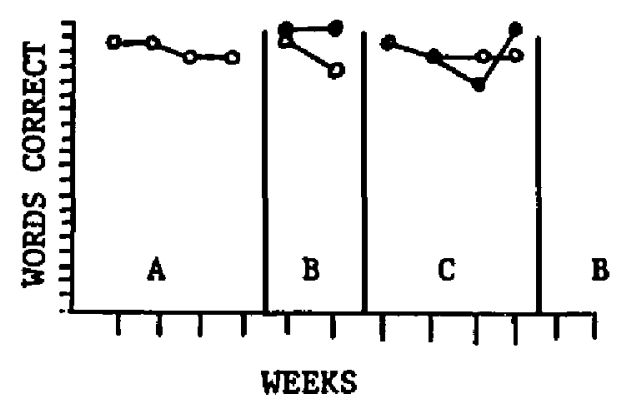

Subject 6

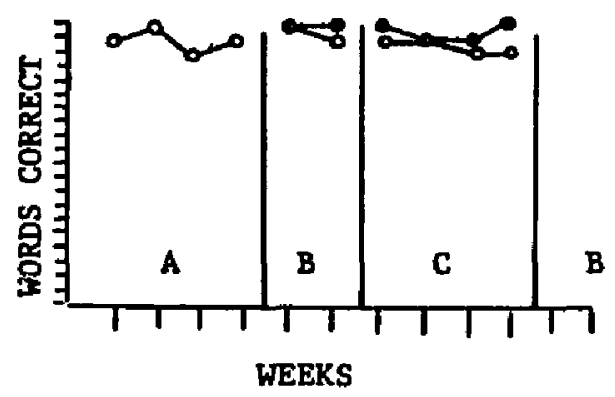

O- Regular Class Performance

Experimental Class Performance 
Weekly Spelling Performances for the Dependent Group Treatment Subgroup.

Swject 1

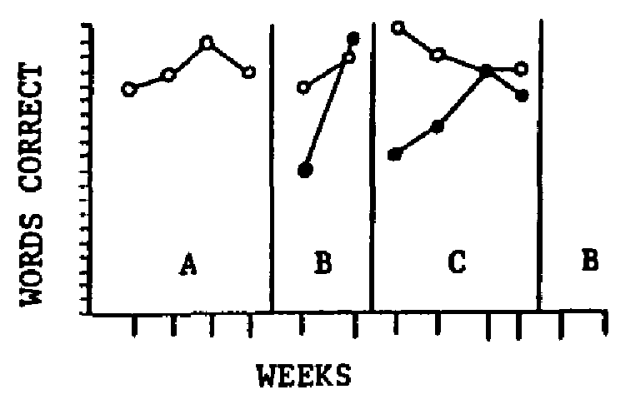

Subject 3

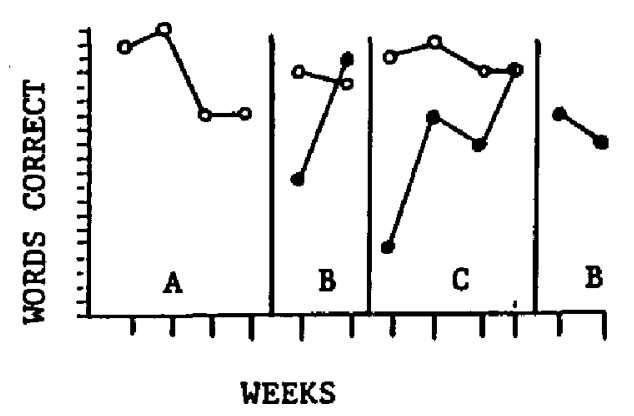

Subject 5

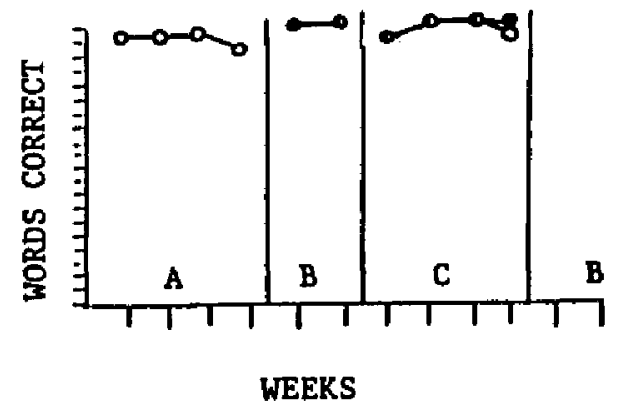

Subject 7

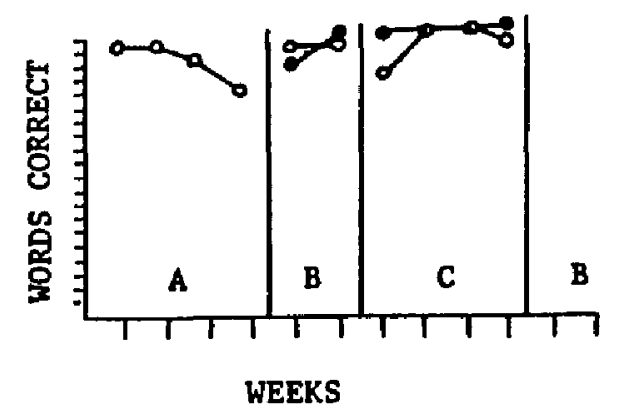

Sub ject 2

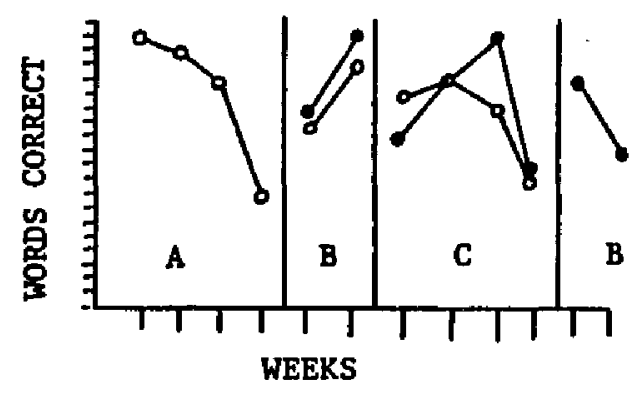

Subject 4

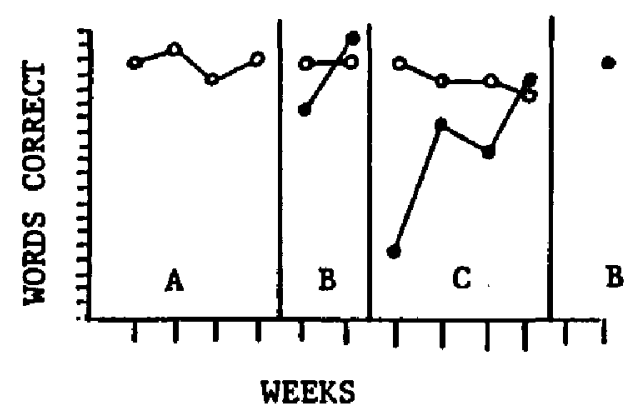

Subject 6

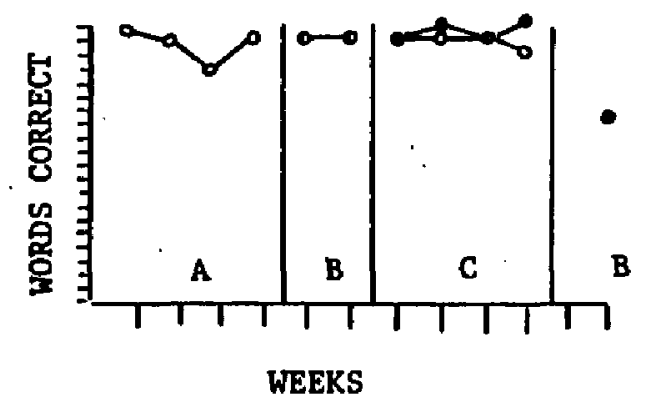

Subject 8

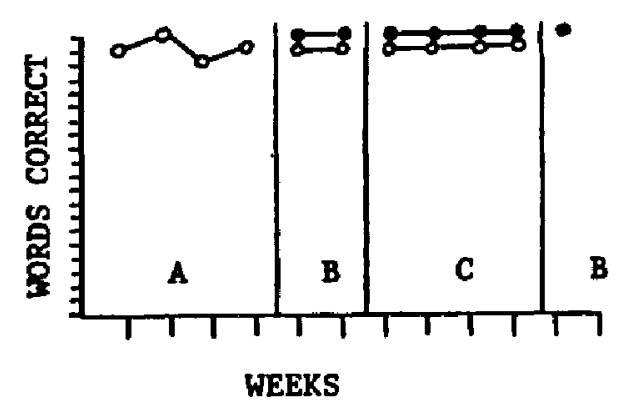

○- Regular Class Performance

$\longrightarrow$ Experimental Class Performance 
Figure 8

Weekly Spelling Performances for the No Incentive Group Treatment Sub group.

Subject 1
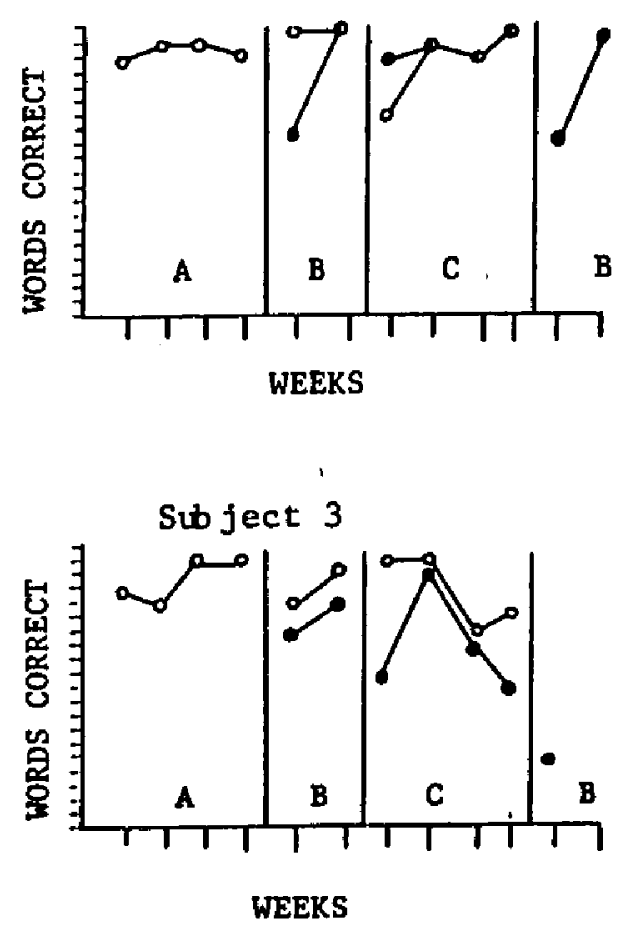

Sub ject 5

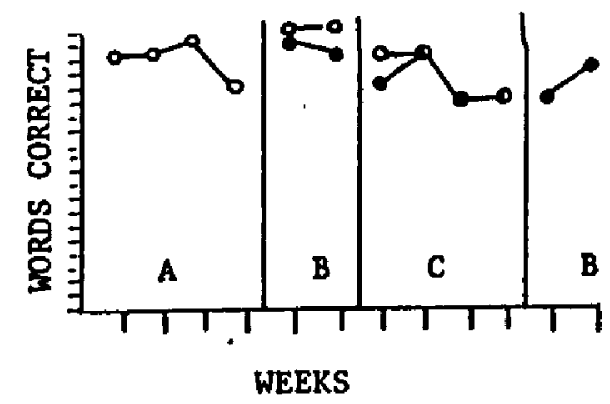

Subject 2
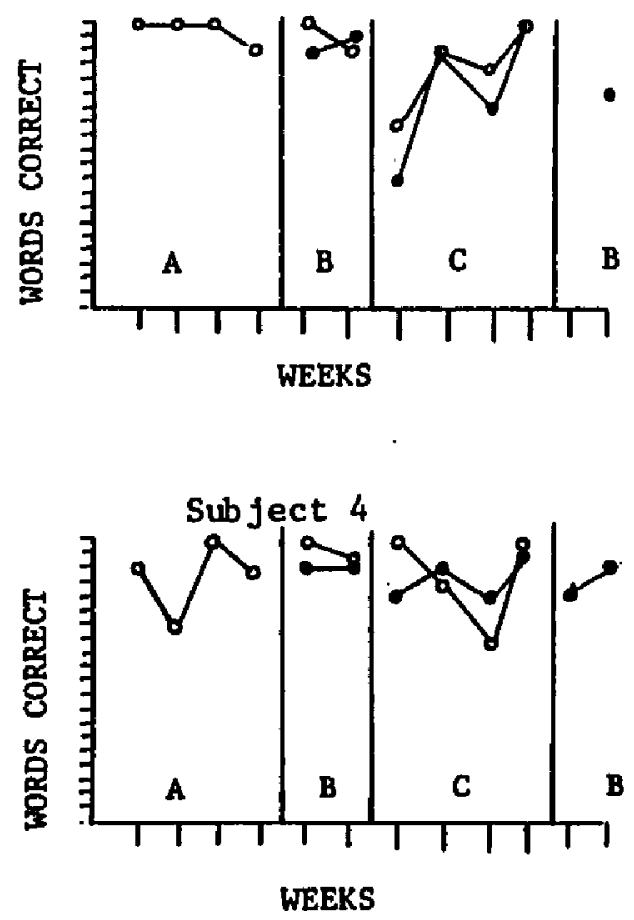

○- Regular Class Performances

- Experinental Class Performance 
Figure 9

Weekly Spelling Performances for the Interdependent Individual

Treatment Subgroup.

Subject 1

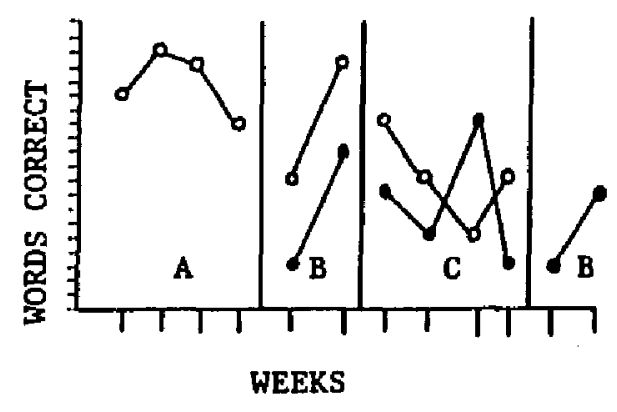

Swject 3
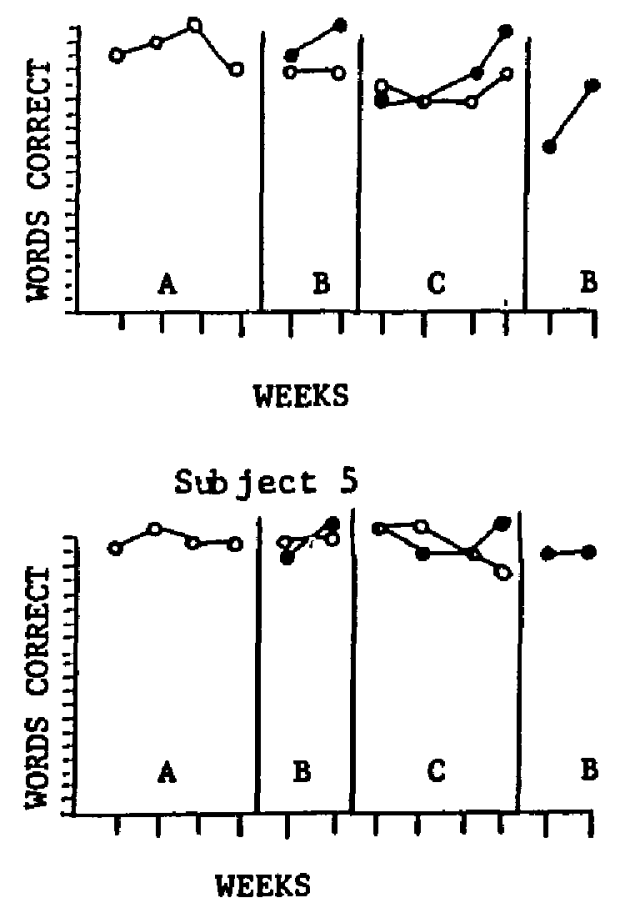

Subject 2

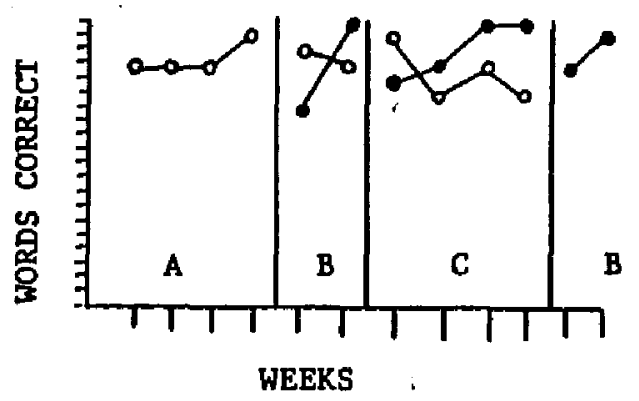

Sub ject 4

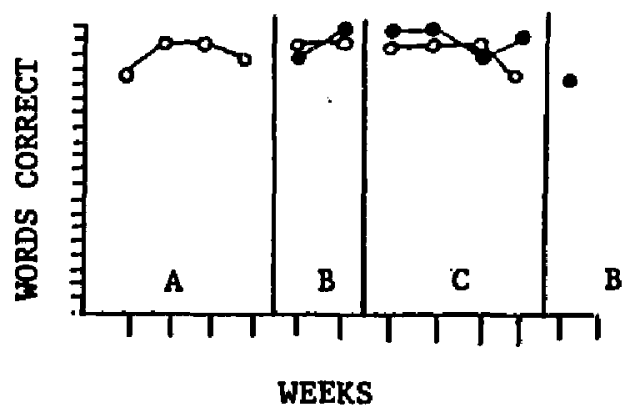

oto Regular Class Performance

- Experimental Class Performance 
Figure 10

103

Weekly Spelling Performances for the Dependent Individual Treatment Subgroup.

Subject 1

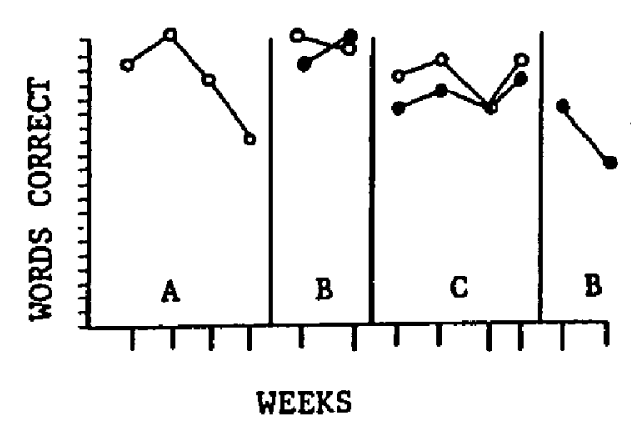

Sub ject 3

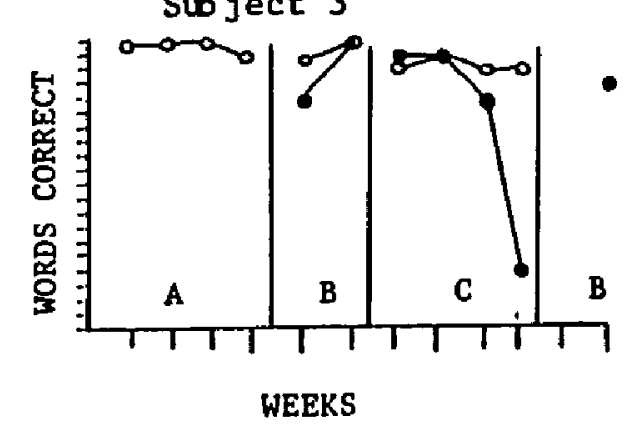

Subject 5

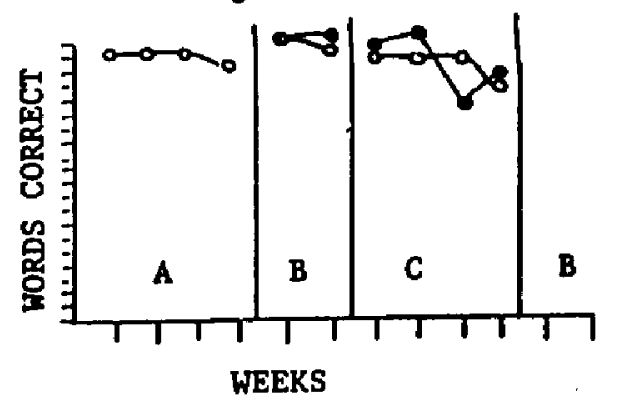

Subject 2
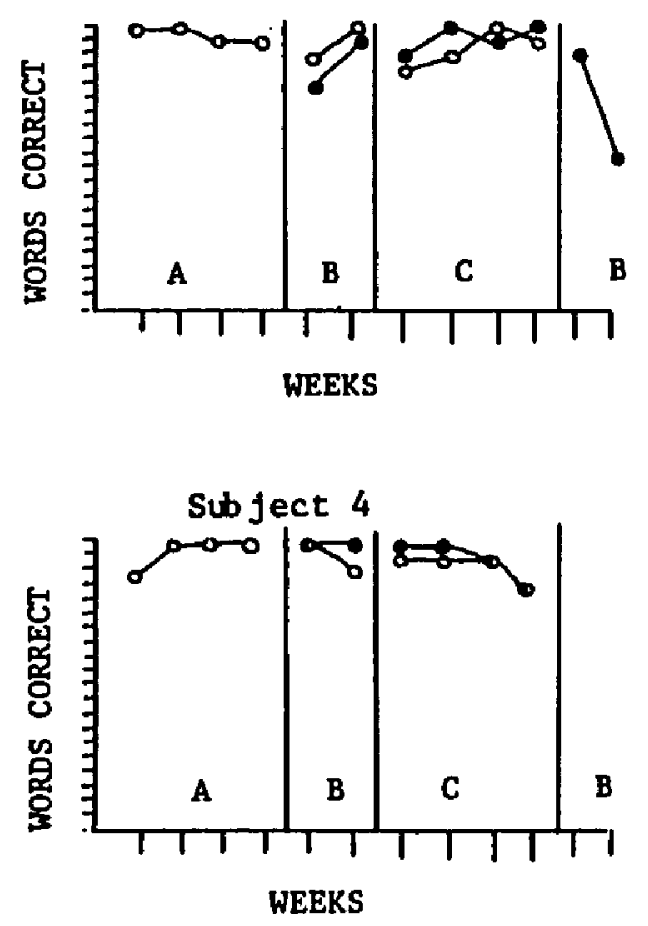

Sub ject 6

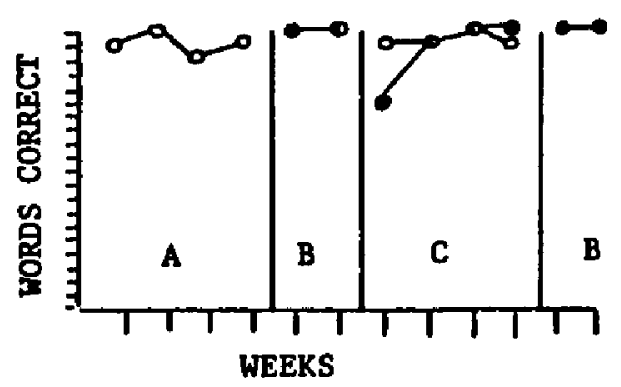

$\multimap$ Regular Class Performances

$\longrightarrow$ Experimental Class Performances 
Figure 11

Weekly Spelling Performances for the No Incentive Individual Treatment Subgroup

Subject 1

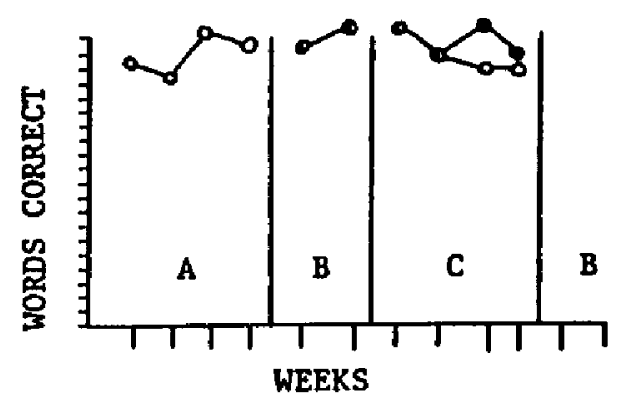

Subject 3

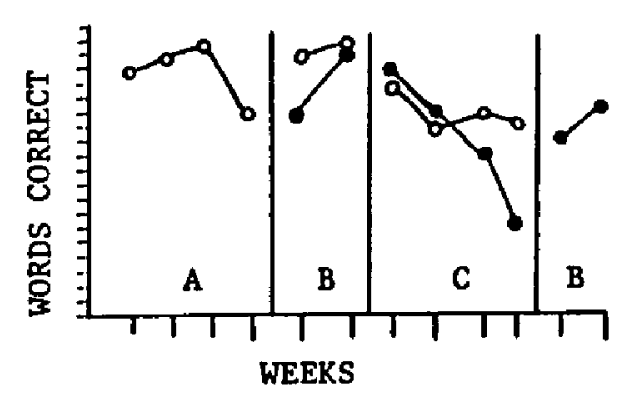

Subject 5

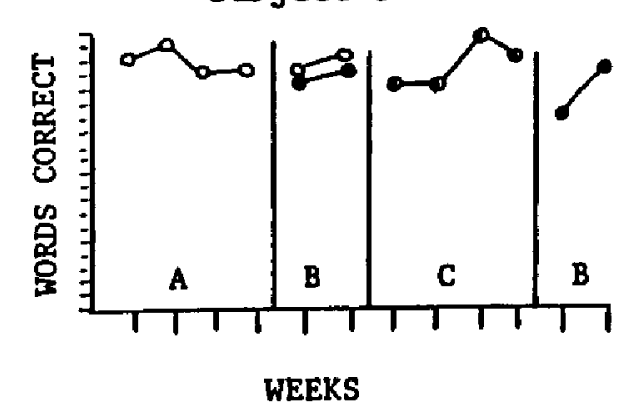

Subject 7

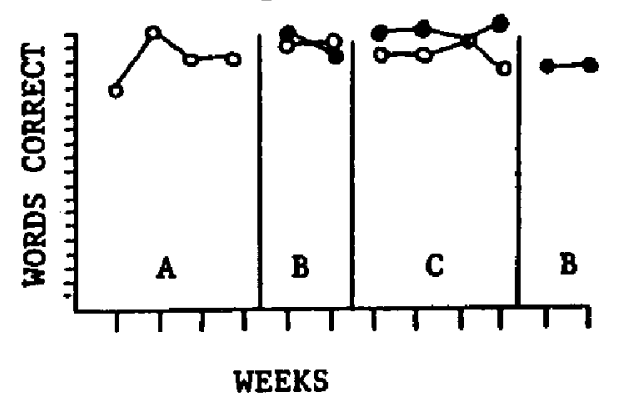

Subject 2

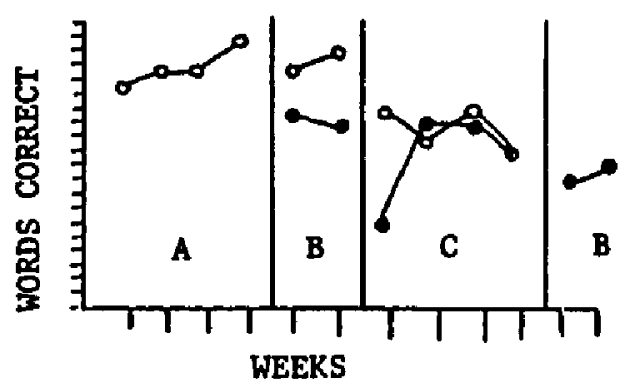

Subject 4

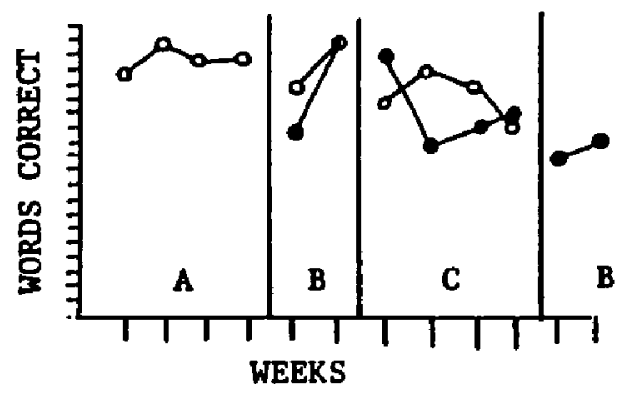

Subject 6

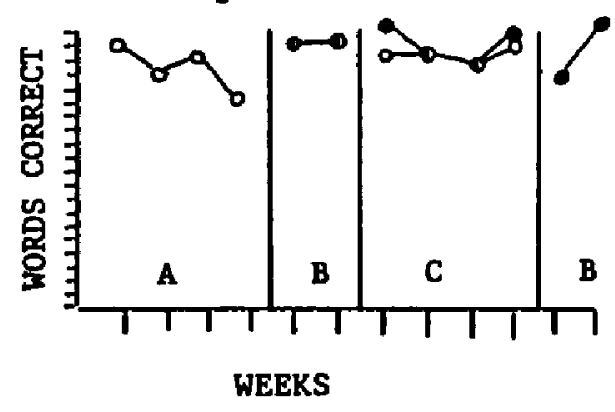

-O Regular Class Performances

$\longrightarrow$ Experimental Class Performances 
posttest. Twenty-one students showed no changes in class unit spelling scores from Baseline 1 to Treatment phases. For 14 students, however, during Baseline 2 and Treatment phases, there were decreases in class unit spelling scores from Baseline 1 levels. Three students demonstrated increases in classroom spelling scores from Baseline 2 to the Treatment phase. Relation Between Acceptability Ratings and Effectiveness of the Instructional Treatments The analysis testing the relations among pretreatment and posttreatment acceptability ratings of the instructional treatment methods and the pretreatment and posttreatment curriculum spelling resulted in correlations ranging from $x=$ .02 to $I=.90$ (see Table 16). Several trends are evident in this correlational data. First, for students in the no incentive groups there is a change in the directionality of the correlations across time. During the pretreatment phase, there was a positive correlation between treatment acceptability and each student's pretreatment curriculum spelling test. However, at the time of the posttest, acceptability ratings are negatively 
Table 16

Correlations Among the Pretreatment and Posttreatment Total CIRP scores and curriçulum spelling Test scores for Each Instructional Treatment Method

\begin{tabular}{|c|c|c|c|}
\hline \multirow[b]{2}{*}{ Source } & Curriculum & \multirow{2}{*}{$\begin{array}{c}\text { Pretreatment } \\
\text { CIRP }\end{array}$} & \multirow{2}{*}{$\begin{array}{c}\text { Posttreatment } \\
\text { CIRP }\end{array}$} \\
\hline & Spelling Test & & \\
\hline \multicolumn{4}{|l|}{ Group Task } \\
\hline Interdependent & $\begin{array}{l}\text { Pretreatment } \\
\text { Posttreatment }\end{array}$ & $\begin{array}{l}.66 \\
.16\end{array}$ & $.90 * *$ \\
\hline Dependent & $\begin{array}{l}\text { Pretreatment } \\
\text { Posttreatment }\end{array}$ & $\begin{array}{l}-.66 * \\
-.14\end{array}$ & -.02 \\
\hline No Incentive & $\begin{array}{l}\text { Pretreatment } \\
\text { Posttreatment }\end{array}$ & 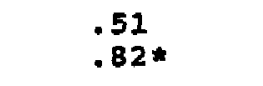 & -.78 \\
\hline \multicolumn{4}{|l|}{ Individual } \\
\hline Interdependent & $\begin{array}{l}\text { Pretreatment } \\
\text { Posttreatment }\end{array}$ & $\begin{array}{l}-.06 \\
-.06\end{array}$ & .02 \\
\hline Dependent & $\begin{array}{l}\text { Pretreatment } \\
\text { Posttreatment }\end{array}$ & $\begin{array}{l}.66 \\
.25\end{array}$ & $-.78 *$ \\
\hline No Incentive & $\begin{array}{l}\text { Pretreatment } \\
\text { Posttreatment }\end{array}$ & $\begin{array}{l}.52 \\
.44\end{array}$ & -.53 \\
\hline
\end{tabular}

Note. The correlation between the posttreatment acceptability rating and the pretreatment curriculum spelling test score has no logical or theoretical meaning and thus is not provided.

$-p<.05$

$\star * 2<.01$ 
correlated to spelling achievement. Another trend evident in four of the six treatment subgroups is a rather robust correlation between posttreatment curriculum spelling scores and posttreatment acceptability ratings. In three of the treatment subgroups (no incentive group, dependent individual, and no incentive individual) this correlation is negative. Only the interdependent group showed a high positive relation between posttreatment curriculum spelling scores and posttreatment acceptability ratings. Remember that, overall, the interdependent group was rated the most acceptable and produced the highest mean spelling scores on the curriculum test. Sociometric Ratings of Peers Within Treatment Subgroups

Two peer social nomination ratings were conducted using the coie, et al. (1982) technique whereby students in each treatment subgroup were asked to identify the three students in the experimental classroom that they liked most (LM) and liked least (LL). From these nominations, social preference (LM-LL) and social impact ratings $(L M+L L)$ were computed. The subgroup means and 
Table 17

Pretreatment and Posttreatment social Preference Peer Ratings for Each of the Treatment Subaroups

\begin{tabular}{|c|c|c|c|}
\hline Treatment Group & & Pretreatment & Posttreatment \\
\hline \multicolumn{4}{|l|}{ Group Task } \\
\hline Interdependent Incentive & $\begin{array}{l}\mathbf{M} \\
\mathbf{S D} \\
\mathbf{N}\end{array}$ & $\begin{array}{l}.16 \\
3.43\end{array}$ & $\begin{array}{l}.67 \\
4.63\end{array}$ \\
\hline Dependent Incentive & $\begin{array}{l}\mathbf{M} \\
\mathbf{S D} \\
\mathbf{N}\end{array}$ & $\begin{array}{l}.50 \\
3.29 \\
8\end{array}$ & $\begin{array}{l}1.12 \\
4.58 \\
8\end{array}$ \\
\hline No Incentive & $\begin{array}{l}M \\
\text { SD } \\
N\end{array}$ & $\begin{array}{r}-.20 \\
5.17 \\
5\end{array}$ & $\begin{array}{l}.00 \\
5.41\end{array}$ \\
\hline \multicolumn{4}{|l|}{ Individual Task } \\
\hline Interdependent Incentive & $\begin{array}{l}\mathbf{M} \\
\mathbf{S D} \\
\mathbf{N}\end{array}$ & $\begin{array}{l}1.00 \\
1.41 \\
5\end{array}$ & $\begin{array}{l}1.20 \\
2.49 \\
5\end{array}$ \\
\hline Dependent Incentive & $\begin{array}{l}M \\
\text { SD } \\
N\end{array}$ & $\begin{array}{l}1.33 \\
2.80 \\
6\end{array}$ & $\begin{array}{l}1.12 \\
4.58 \\
6\end{array}$ \\
\hline No Incentive & $\begin{array}{l}M \\
S D \\
N\end{array}$ & $\begin{array}{l}1.12 \\
2.99 \\
7\end{array}$ & $\begin{array}{l}.00 \\
4.41 \\
7\end{array}$ \\
\hline
\end{tabular}

a

the possible range for these scores is $-N$ to $+N$ 
standard deviations of these social preference ratings appear in Table 17 . In the first analysis, each student's social preference rating was evaluated across three independent variables: time (pretreatment and posttreatment), incentive structure (interdependent, dependent, and no incentive), and task structure (group and individual). The results of this $2 \times 2 \times 3$ ANOVA indicated no significant main or interaction effects (see Table 18). In the second analysis, each student's social impact rating also was evaluated across the three independent variables of time, incentive structure, and task structure. The means and standard deviations of these social preference ratings appear in Table 19. The results of this $2 \times 2 \times 3$ ANOVA also indicated no significant main or interaction effects (see Table 20).

Table 21 indicates how the social impact, preference, and ultimately status ratings change from pretreatment to posttreatment in each treatment subgroups. Student's exposure to one of the six treatment methods resulted in increases in social impact in 248 of the cases, increases in 
Table 28

Source Toble for a Repeated Measures avova Examining Pretreatment and Posttreatment social Preference Ratings of Students in Each Incentive structure and Task structure

\begin{tabular}{lccccc}
\hline Source & SS & df & Ms & F & P \\
\hline Between subjects & & & & & \\
Task & 7.09 & 1 & 7.09 & .37 & .545 \\
Incentive & 1.66 & 2 & .83 & .04 & .957 \\
Within subjects & & & & & \\
Time & .08 & 1 & .08 & .01 & .901 \\
Task X Time & 2.57 & 1 & 2.57 & .49 & .487 \\
Incentive X Time & .87 & 2 & .44 & .08 & .919 \\
Task X Incentive & 4.28 & 2 & 2.14 & .11 & .893 \\
Task X Incentive X Time & 1.85 & 2 & .93 & .18 & .838 \\
& & & & & \\
\hline
\end{tabular}


Table 29

Pretreatment and posttreatment soclal Impact Peer Rat ings for Each of the Treatment subgroups

\begin{tabular}{|c|c|c|c|}
\hline Treatment Group & & Pretreatment & Posttreatment \\
\hline \multicolumn{4}{|l|}{ Group Task } \\
\hline Interdependent Incentive & $\begin{array}{l}\text { H } \\
\text { SD }\end{array}$ & $\begin{array}{l}4.50 \\
2.42 \\
6\end{array}$ & $\begin{array}{l}5.00 \\
2.53 \\
6\end{array}$ \\
\hline Dependent Incentive & $\begin{array}{l}\text { M } \\
\text { SD } \\
N\end{array}$ & $\begin{array}{l}4.75 \\
1.39 \\
8\end{array}$ & $\begin{array}{l}4.87 \\
1.81 \\
8\end{array}$ \\
\hline No Incentive & $\begin{array}{l}M \\
\mathbf{S D}\end{array}$ & $\begin{array}{l}6.40 \\
3.50 \\
5\end{array}$ & $\begin{array}{l}4.40 \\
1.81 \\
5\end{array}$ \\
\hline \multicolumn{4}{|l|}{ Individual Task } \\
\hline Interdependent Incentive & $\begin{array}{l}\mathbf{M} \\
\mathbf{S D}\end{array}$ & $\begin{array}{l}4.60 \\
1.94 \\
5\end{array}$ & $\begin{array}{l}4.80 \\
1.09 \\
5\end{array}$ \\
\hline Dependent Incentive & $\begin{array}{l}\mathbf{M} \\
\mathbf{S D} \\
\mathbf{N}\end{array}$ & $\begin{array}{l}5.33 \\
2.66 \\
6\end{array}$ & $\begin{array}{l}3.33 \\
1.21 \\
6\end{array}$ \\
\hline No Incentive & $\begin{array}{l}\mathbf{M} \\
\mathbf{S D}\end{array}$ & $\begin{array}{l}4.12 \\
1.36 \\
7\end{array}$ & $\begin{array}{r}3.25 \\
.89\end{array}$ \\
\hline
\end{tabular}

a the possible range for these scores is $-2(N)$ to $+2(N)$ 
Table 20

Source Table for a Repeated Measures Nova Examining

Pretreatment and Postcreatment social Impact Ratings of students in Each Incentive structure and Task structure

\begin{tabular}{|c|c|c|c|c|c|}
\hline Source & ss & df & MS & $\mathbf{F}$ & $p$ \\
\hline \multicolumn{6}{|l|}{ Between subjects } \\
\hline Task structure & 10.22 & 1 & 10.22 & 2.44 & .128 \\
\hline Incentive structure & .43 & 2 & .22 & .05 & .950 \\
\hline \multicolumn{6}{|l|}{ Within Subjects } \\
\hline Time & 8,34 & 1 & 8.34 & 2.49 & .124 \\
\hline Task X Time & .85 & 1 & .85 & .26 & .616 \\
\hline Incentive $x$ Time & 9.74 & 2 & 4.87 & 1.45 & .248 \\
\hline Task $\mathrm{x}$ Incentive & 8.87 & 2 & 4.43 & 1.06 & .359 \\
\hline $\begin{array}{l}\text { Task } x \text { Incentive } x \\
\text { Time }\end{array}$ & 8.64 & 2 & 4.32 & 1.29 & .289 \\
\hline
\end{tabular}


Table 21

Pretreatment to Post reatment changes in socionetric status for

Students in the Instructional Treatment subgroups

\begin{tabular}{|c|c|c|c|c|c|c|c|c|c|c|c|}
\hline \multirow[b]{3}{*}{ Group } & \multicolumn{3}{|c|}{ Pretreatment } & \multicolumn{3}{|c|}{ Posttreatment } & \multicolumn{5}{|c|}{ Change } \\
\hline & & & & & & & \multicolumn{5}{|c|}{ Group } \\
\hline & SI & $\mathbf{S P}$ & GRP & SI & SP & GRP & SI & $\mathbf{S P}$ & + & 0 & - \\
\hline
\end{tabular}

Group Task

Interdependent

\begin{tabular}{|c|c|c|c|c|c|c|c|c|c|c|}
\hline 1 & 4 & -2 & NEU & 2 & -2 & NEG & - & 0 & & 1 \\
\hline 2 & 2 & 0 & NEU & 9 & -7 & REJ & + & - & & 1 \\
\hline 3 & 3 & 1 & NEU & 6 & 4 & POP & + & + & 1 & \\
\hline 4 & 4 & 2 & NEU & 6 & 6 & POP & + & + & 1 & \\
\hline 5 & 5 & 5 & POP & 4 & 2 & NEU & - & - & & 1 \\
\hline
\end{tabular}

Dependent

\begin{tabular}{|c|c|c|c|c|c|c|c|c|c|c|}
\hline 7 & 7 & -5 & REJ & 4 & 0 & NEU & - & + & 1 & \\
\hline 8 & 6 & -2 & NEU & 5 & -5 & REJ & - & - & & \\
\hline 9 & 4 & -2 & NEU & 7 & -5 & REJ & - & + & & \\
\hline 10 & 4 & 0 & NEU & 1 & -2 & NEG & - & - & & \\
\hline 11 & 4 & 2 & NEU & 6 & 6 & POP & + & - & 1 & \\
\hline 12 & 6 & 4 & POP & 6 & 6 & POP & + & 0 & & 1 \\
\hline 13 & 3 & 3 & NEU & 5 & 5 & POP & + & + & 1 & \\
\hline 14 & 4 & 4 & POP & 5 & 3 & NEU & - & - & & \\
\hline
\end{tabular}


Table 22 (continued)

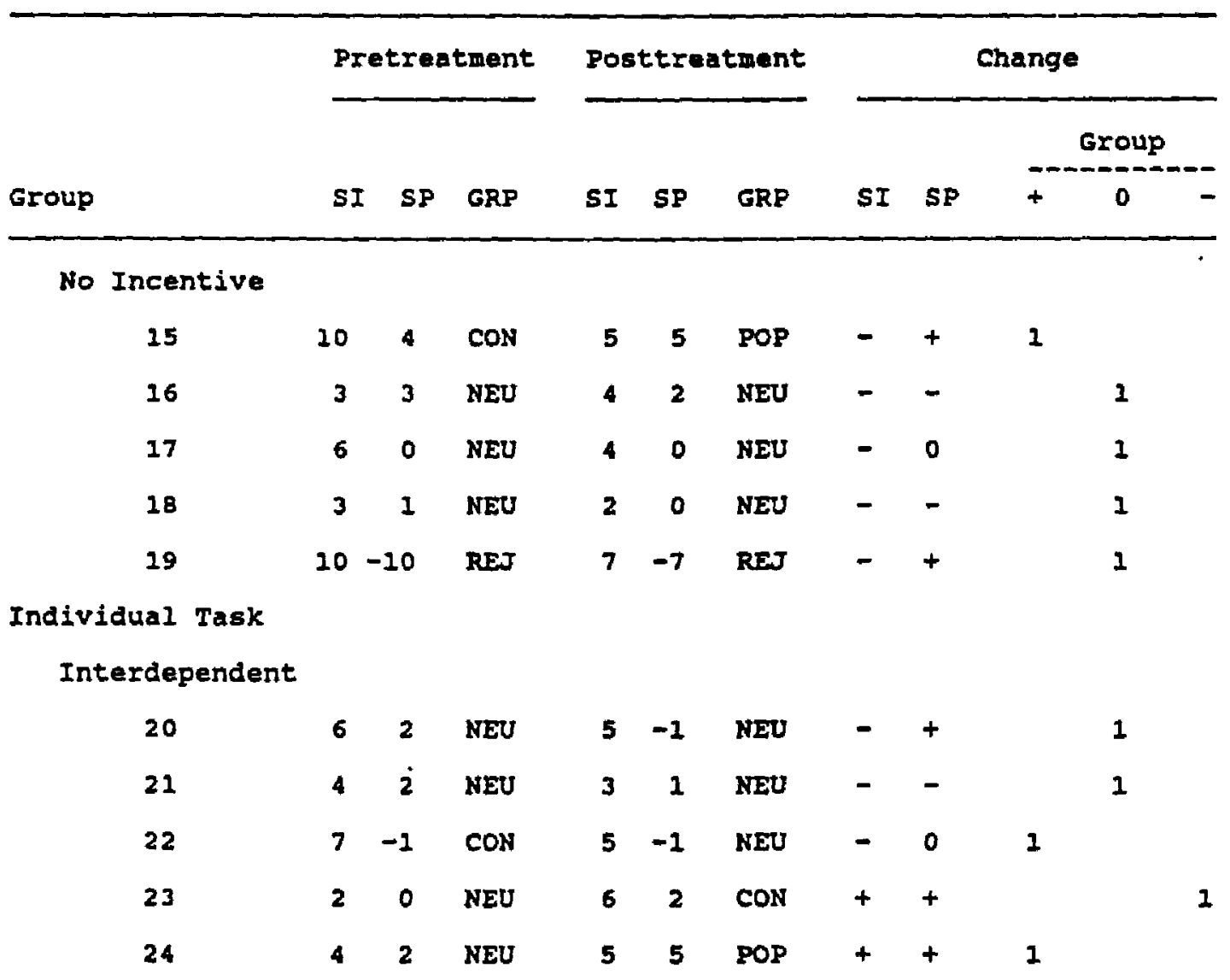


Table 21 (continued)

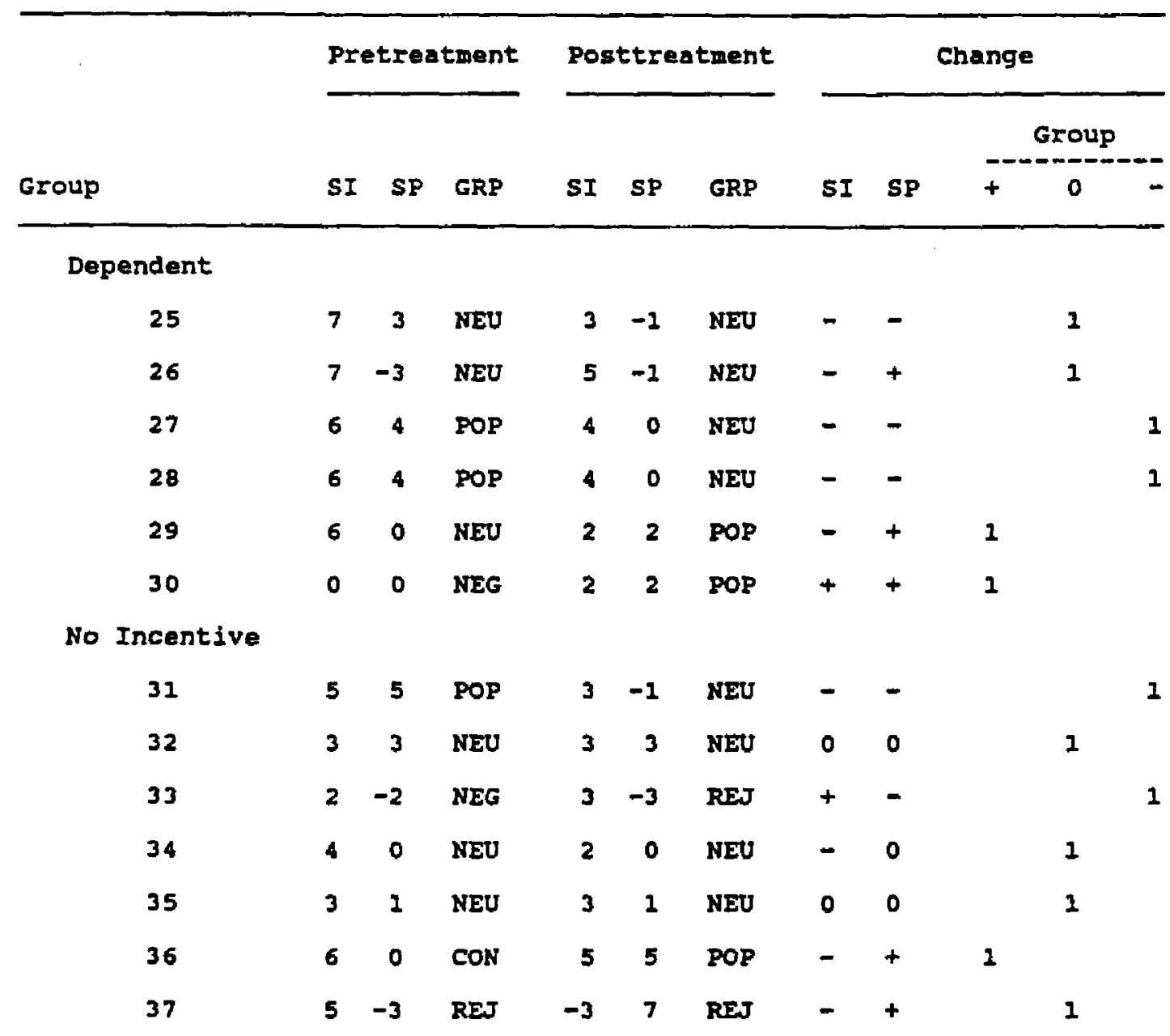


social preference in $40 \%$ of the students, and changes in social group in 628 of the students. specifically, of those 23 students whose social status changed, 11 were in a positive direction (e.g., Rejected to Neutral, Neutral to Popular) and 12 in a negative direction (e.g., Neutral to Controversial, Popular to Neutral). These changes were as prevalent under the group task structure as the individual task structure. Changes were far more likely to occur under one of the incentive conditions as opposed to a no incentive subgroup. For example, in the incentive groups, 1008 of the students in the interdependent group, $87 \%$ of the students in the dependent group, $60 \%$ of the students in the interdependent individual, and $67 \%$ of the dependent individual subgroups changed in social status. Whereas, only $20 z$ of the students in the no incentive group and 378 of the students in the no incentive individual subgroups exhibited changes in social status. Summary of Results with Respect to Major Predictions

This study was designed to test eight predictions. Empirical evidence was reliably 
collected for each prediction and can be summarized as follows:

Prediction 11: supported. The posttreatment WRAT-R spelling achievement of students in the treatment school was found to be significantly greater than the spelling achievement of students in the control school.

Prediction \#2: Refuted. The spelling achievement of students as measured by the weekly spelling tests in the incentive groups, was not significantly greater than the spelling achievement of the no incentive groups.

Prediction \#3: Refuted. The students in the group task structure did not have significantly greater spelling achievement than students in the individual task structure.

Prediction \#4: supported. The treatment acceptability ratings of the experimental and control schools were statistically equivalent.

Prediction \#5: Supported. The pretreatment acceptability ratings of the control group did not significantly change from pretreatment to posttreatment. 
Prediction \#6: supported. The treatment acceptability ratings of the treatment subgroups did significantly change from pretreatment to posttreatment.

Prediction 17: Mixed Results. The pretreatment treatment acceptability ratings and posttreatment spelling achievement scores were not highly correlated consistently. The degree of the relations varied across the treatment subgroups. A high positive correlation was found in the interdependent group treatment subgroup. Moderately high negative correlations were found in the no incentive group, dependent individual, and no incentive individual treatment subgroups. Prediction \#8: Refuted. The sociometric ratings of students in the group task structures did not change significantly more than students in the individual task structures. 


\section{Discussion}

This study was designed to evaluate the affects of varying the incentive and task structures of group contingencies on fifth-grade students' spelling performances, ratings of treatment acceptability, and peer social interactions. Specifically, this study sought to answer three general questions. First, is there a difference in the relative effectiveness of group contingencies that vary according to task and incentive structures? Second, do interdependent and dependent forms of group contingencles influence the social status of the group members? Third, do student's ratings of the social acceptability of treatments relate to the effectiveness of the treatment's outcomes?

To answer these questions, a treatment study was completed and a series of empirical predictions were tested. Specifically, the experimental treatments were predicted to improve the spelling achievement of all students. However, in comparison to control groups, varying the incentive and task structures was predicted to result in greater improvements in spelling achievement for 
students in the treatment subgroups where incentives were available and where the group task structure was used.

Treatment acceptability was hypothesized to be a relatively stable construct that would not be significantly influenced by the mere passage of time. Thus, prior to treatment and in the absence of naturalistic exposures to the independent varaibles, the acceptability ratings of students were predicted to be statistically equivalent. After four weeks of exposure to the independent variables, however, the acceptability ratings of students in the treatment subgroups were predicted to change significantly.

A significant correlation was predicted between pretreatment acceptability ratings and posttreatment spelling achievement. Thus, conceptually integrating the acceptability and effectiveness data.

Finally, because the use of group task structures were believed to increase social interactions between students, it was predicted that there would be significantly greater changes in the sociometric status of students in the group 
task structure than would be found in the students in the individual task structure. yajor Findings

Acceptability. The results of this study supported all three predictions made about student's treatment acceptability scores. First, pretreatment acceptability ratings of all of the treatment groups were not significantly different from the acceptability ratings of the control group. Second, the results also largely supported the prediction that there would be significant changes from the pretreatment to posttreatment acceptability ratings of the treatment methods by students who actually experienced one of the treatments. Only the dependent individual treatment subgroup did not show significant pretreatment to posttreatment changes in acceptability ratings. Third, the prediction that the acceptability ratings of the control group would not significantly change from pretreatment to posttreatment was also supported. Collectively, these findings support the notion that in an analogue situation, acceptability ratings do not significantly change over a 6 to 7 
week period. However, when students actually receive one of the treatment methods that they have rated, their acceptability of these treatments changes. Thus, experience with a particular treatment, whether positive or negative, seems to be a very meaningful factor in the evaluation of a treatment.

Spelling achievement. One of the three predictions was supported about the affects of varying incentive and task structures of the treatment subgroups on spelling achievement. No differences existed between the treatment and control groups at pretreatment, however, students' average spelling periormances in each treatment subgroup increased significantly from pretreatment to posttreatment. Based on the results of the WRAT-R Spelling subtest, the average increases of students in a treatment subgroup was significantly greater than the increases of the group of students from the control school.

Analyses did not indicate statistically significant spelling achievement differences between the students based upon the incentive or task structures of the treatment subgroups. This 
lack of a significant effect may be due to a variety of factors, such as the relatively short amount of time students were in the spelling treatments (10 minutes for 2 to 3 times a week), poor motivation of students in the treatment groups, or a true lack of effectiveness of the incentive and task structures.

Acceptability-effectiveness relations. The results did not clearly support nor refute the hypothesized relation between the pretreatment acceptability ratings and the posttreatment spelling achievement scores. Within most treatment subgroups (interdependent group, dependent group, interdependent individual, and dependent individual) the correlations between students' pretreatment acceptability ratings and posttreatment spelling scores was quite low. The highest correlations ( $r=.82$ and $r=.44$ ) between pretreatment acceptability and posttreatment spelling scores were found in the no incentive subgroups (e.g., no incentive group and no incentive individual). The correlations between pretreatment acceptability and the posttreatment curriculum spelling test in the remaining treatment 
groups were very low. For example, this correlation approached zero $(x=-.06)$ in the interdependent individual subgroup.

Several treatment subgroups, however, showed relatively high correlations between students' posttreatment acceptability ratings and posttreatment spelling scores. For example, the interdependent group subgroup had a high positive correlation $(x=.90)$. When this finding is incorporated with the results of the spelling achievement measures, it indicates that the interdependent group treatment method is the best or preferred method. It is the most acceptable while being as effective as any of the other methods.

Perhaps the most interesting correlational results occurred in the no incentive groups. Both the no incentive group treatment and the no incentive individual treatment subgroups had high positive correlations between the pretreatment acceptability ratings and the posttreatment curriculum spelling test. However, both groups had high negative correlations between posttreatment acceptability ratings and the posttreatment 
curriculum spelling test. Because the average curriculum spelling score remained relatively constant in these analyses, these reversals in correlations seem to be due to the significant decreases in acceptability that occurred over time. Sociometric ratings. The results of this study did not support the prediction that the sociometric ratings of students in the treatment subgroups using group task structures would change significantly more than the sociometric ratings of students in the treatments using individual task structures. No statistically significant differences in sociometric ratings were found in any of the levels of the independent variables. students, however, were only interacting in their treatment subgroups for about 30 minutes a week. Thus, one explanation for the failure to support the prediction is that there was not enough time for the cumulative effects of the treatment conditions to impact students' social status.

Single-case analyses of students' peer nominated social status indicated that the incentive structures affected many students' social status. Students in the incentive subgroups 
(interdependent group, dependent group, interdependent individual, dependent individual) had more changes in social impact, social preference, and social status than the students in the no incentive groups.

Comparison of Present Results With Previous Research

The present study provides several unique contributions to the educational and psychological literature. This study was designed with the belief that group treatments potentially may result in side effects. Consequently, variables such as treatment integrity, peer-rated social status, and spelling performances in the regular classroom as possible indices of side effects. This study is one of the first studies to examine students' acceptability ratings over a 6 to 7 week period. This procedure allowed an initial examination to be made of the reliability and stability of students' treatment acceptability ratings as measured by the CIRP. This study is also unique with respect to past acceptability research in that two types of control groups were used. One control group received no treatment and was used to compare the 
pretreatment to posttreatment changes in the dependent variables. The second type of control group experienced the spelling instruction, but did not receive an incentive (e.g., no incentive group treatment and the no incentive individual treatment subgroups). These control groups allowed comparisions to be made between each of the incentive structures and the exposure of the subjects to the experimental classroom.

This study is one of the first studies to evaluate students' treatment acceptability measures before and after the students were actually involved in one of the treatment conditions they rated. A similar procedure was employed by shapiro and Goldberg (1987). They used an alternating treatments design with an interdependent and dependent group contingency, so each student experienced both treatment methods before the posttreatment acceptability evaluation. The acceptability portion of present study used a split-plot factorial design, where each subject rated the acceptability of six treatment methods before and after actually experiencing only one of the treatment methods. Shapiro and Goldberg 
(1986, 1987) have completed two studies using an alternating treatments application of group contingencies as a modification to the spelling curriculum in the regular classroom environment. The present study was conducted outside of the regular classroom as a resource supplement to the regular spelling curriculum.

The present study and the Shapiro and Goldberg (1986, 1987) both have good ecological validity. All of these studies were conducted in the actual school environment, but they assessed the use of group contingencies in different niches in the school ecosystem. The Shapiro and Goldberg (1986, 1987) studies examined the used of group contingencies as a modification to the regular classroom curriculum. The present study examined the use of group contingencies as part of an academic resource program, very similar to a reading or spelling laboratory. The present study supports the previous findings (Allen et al., 1980; Greenwood \& Hops, 1981; Lovitt et al., 1969; McCarty et al., 1977; McLaughlin, 1981, Shapiro Goldberg, 1986; Sloggett, 1971; Wodarski et al., 1973) that there 
are no significant differences between group contingencies in regard to their effectiveness. The present study found that the use of group contingencies lead to significant increases in spelling performances on the WRAT-R and the Curriculum spelling test. This supports the basic findings of several previous studies (Allen et al., 1980; Chadwick \& Day, 1971; Evans Oswalt, 1968; Hamblin \& Smith, 1972; Haring Hauck, 1969; Harris * Sherman, 1973; Hopkins et al., 1971; Lovitt et al., 1969; McCarty et al., 1977; McLaughlin, 1981; Meloney Hopkins, 1973; Shapiro \& Goldberg, 1986; sloggett, 1971; Wodarski et al., 1973). However, in the present study, students' weekly performances in their spelling textbook did not increase significantly as a result of the group contingencies.

The present study supported the previous findings (Elliott, Turco, E Gresham, 1987; Shapiro \& Goldberg, 1986, 1987) that there are significant differences between group incentive structures with regard to social acceptability. In the present study, like the previous studies (Elliott, Turco, \& Gresham, 1987; Shapiro \& Goldberg, 1986), the 
interdependent group contingencies were more acceptable than the dependent group contingencies.

The present study apparently contradicts Shapiro and Goldberg's (1987) findings that students' acceptability ratings of group contingencies for spelling performance increase from pretreatment to posttreatment. The differences between the Shapiro and Goldberg (1987) study and the present study may help to understand the differences between the results. In the Shapiro and Goldberg (1987) study, the students were in an alternating treatments design, and thus each student was given naturalistic exposure to each of the treatment methods. In the present study, a split-plot factorial design was used, so each only actually experienced one of six different treatment methods. In addition, in the shapiro and Goldberg (1987) study, there were significant increases in spelling achievement from baseline to the alternating treatments phase. In the present study, most students did not increase their spelling achievement scores from baseline to treatment phases. If students were dissatisfied with the effectiveness of their own treatments, 
then they may have generalized their

dissatisfaction to the other treatment methods and lowered the overall acceptability of all of the treatment methods.

The present study supports the previous findings of Pigott et al. (1985). In the Pigott study, an ABABA withdrawal design was used to examine the effects of an interdependent group contingency on math achievement. During the first baseline and last baseline Pigott et al. (1985) had students rank order the five subjects that they would most like to sit with during a class period. Their results indicated no significant negative side effects as a result of using the group contingency. The peer nomination procedure used by Pigott was basically the same as the procedure that was used in the present study. The only major difference was that the students in the present study only nominated three classmates. The present study provides partial support to the results of several previous studies (Axelrod, 1973; Packard, 1970; Shores et al., 1977) that indicated that the use of group contingencies may lead to negative peer pressures. In the present study the social 
impact ratings of 68 of the students, the social preference ratings of 41 of the students, and the social status of $30 \%$ of the students in the treatment subgroups decreased from pretreatment to posttreatment. However, the previous atudies used anecdotal and subjective evaluations of students' behaviors to determine peer pressure. The present study used written peer nominations to determine the effects of group treatment on social status. The present study gives partial support to the results of previous studies (Evans \& Oswalt, 1968; McCarty et al., 1977; Sloggett, 1971) which indicate that the use of group contingencies can produce positive peer influences. In the present study, the social impact ratings of $27 \%$ of the students, the social preference ratings of $27 \%$ of the students, and the social status of $32 \%$ of the students increased from pretreatment to posttreatment. Again, however, there are differences in the measurement techniques used in the previous studies and the present study. For example, sloggett (1971) used anecdotal information to determine that the use of group contingencies led to positive peer interactions. 
Limitations, Shortcomings, and Cautions About This Study

Test-retest reliablifity. The test-retest correlations of the Children's Intervention Rating Profile (CIRP) were generally low $(x=.08$ to $x=$ .74). Across the treatment subgroups these test-retest correlations did indicate some general trends. First, it was hypothesized that students' acceptability ratings of the treatment method they experienced would change from pretreatment to posttreatment. Thus, the test-retest reliability of the CIRP was expected to be relatively low for these treatment subgroups. The results of this study supported this notion, because the reliability coefficients were lowest for students rating the acceptability of the treatment method of which they were assigned. students' ratings of the treatment methods of which no naturalistic exposures occurred, were expected to remain constant. This prediction was partially supported in the treatment subgroups and the control group. In addition to interpreting these results as an indication that the CIRP is an unreliable instrument, the fluctuations in the pretreatment to 
posttreatment acceptability ratings in these groups may be potentially caused by several factors. First, the low reliability coefficients may be a result of instability in the acceptability construct itself. Acceptability may be a rapidly changing construct that is only stable over relatively short periods of time. Also, the reliability of the acceptability construct as measured by the CIRP may be a function of the age of the respondents. (i.e., the cognitive development of fifth-graders may inconsistently influence acceptability ratings).

student attrition. student attrition rates were high between the treatment phase and the reversal phase. The highest attrition rates occurred in the treatment subgroups using group task structures. In the interdependent group and dependent group subgroups $100 \%$ of the students failed to complete the reversal phase. In the no incentive group $40 \%$ of the students dropped-out during the reversal phase. Although this study failed to show statistically significant differences between the task structures, this attrition data suggests that task structures do 
have an impact on the social cohesiveness of student subgroups. During the treatment phase, students receiving the group task structures were asked to interact with each other to improve their spelling performances. Thus, the procedures of this study were designed to encourage the development of peer relationships and cooperative learning. During the reversal phase, the incentives were removed for all of the students in each of the subgroups. However, for the students in the subgroups with group task structures, the reversal phase meant that they could no longer interact with the other students in their study subgroups. This inability to interact with the other students in the subgroup is a viable explanation of the much higher attrition rates for students in the subgroups with group task structures.

Experimental classroom. One of the limitations of the present study is that it was designed to take place outside of the regular class setting. During the planning stage of this study, conducting the study in a highly structured and closely monitored experimental classroom was 
considered a strength of the study. The experimental classroom concept allowed the researcher to create six heterogeneous experimental subgroups by selecting students from homogeneously stratified regular education classes. This selection process also eliminated many of the previously established peer groups that existed in the regular class settings and facilitated the development of new peer relationships in each treatment subgroup in the experimental classroom. To eliminate any order effects or any confounding effects that the time of day would have on the results of the study, the treatment subgroups were called to the experimental classroom on a rotating schedule. These general treatment procedures resulted in students being called to the experimental classroom at various times during the first three to four hours in the school day. The fifth-grade teachers in the experimental school generally were cooperative with the demands of the experimental procedures. Occasionally, however, conflicts occurred between the reasonable demands of the regular classroom and the experimental classroom schedule. Whenever possible, the 
experimental teacher modified the schedule of the experimental classroom to accommodate the requirements of the regular classroom. It was, however, frequently necessary for the experimental teacher to proceed with the study without all of the students in a particular treatment subgroup. Shapiro and Goldberg (1986, 1987) have conducted two studies that have evaluated the used of group contingencies in the regular classroom environment. In their studies, one of the researchers (Goldberg) was the classroom teacher, and the group contingencies were conducted each day as part of the regular spelling instruction. Shapiro and Goldberg's (1986, 1987) procedure reduces the treatment integrity and missing data problems that may have effected the results of the present study; however, Shapiro and Goldberg's (1986, 1987) studies can be criticized because of the strong possibility of experimenter bias. Another issue that is important to consider when evaluating the results of the present study is that because of personal tragedies, three different experimental teachers were required to conduct this study. Although, the researcher individually 
trained each teacher, personally observed, and video taped each teacher's performances in the experimental classroom there may have been teacher variables that influenced the results of the study. One of the major research goals of the present study was to evaluate the hypothesized relationship between pretreatment acceptability and posttreatment academic performances. Although the results of the present study did not find highly significant correlations between acceptability and effectiveness, we should not discount the hypothesis yet. The best test of the acceptability-effectiveness relation should occur in a study that shows significant differences in the effectiveness of the treatment groups. In the present study, no significant differences in the effectiveness of the treatments were found. Thus, resulting in a rather restricted range of effectiveness scores. In addition, the treatment subgroups used in this study were relatively small, which also affected the results of the correlational analysis.

Stimulus words. One negative side effect of the experimental procedures was noted in the 
present study. The word lists that were selected to be used in this study were complete spelling units taken from the spelling text book being used in the regular classrooms. The unit that was taught each week in the experimental classroom was the word list that was going to be taught in the regular classroom the following week. Thus, work in the experimental classroom should improve students' spelling scores in the regular classroom. Unfortunately, when examining the results of the single-case analyses, the spelling performances of some students in the regular class declined across time. The regular classroom teachers reported to the experimenter that they did not attribute the performance losses of their students to the effects of the experimental treatments, but to the increased difficulty of the words in the spelling text during the study. However, one student reported to the regular classroom teacher that he/she didn't have to study the spelling words in the regular class because he/she already learned them the week before in the experimental classroom. Thus, the decreases in spelling achievement in some students may have been 
due to the increasing difficulty of the curriculum or to motivational factors.

Withdrawal design. In the present study a withdrawal design was used. A withdrawal design is desirable experimentally because it allows researchers to determine if changes in the dependent variable are maintained in the absence of the independent variable. However, in school settings, the use of withdrawal designs has some negative side effects. It appears to have contributed to the rather high student attrition during the final two weeks of this study.

Generalization. The present study was only conducted with fifth-grade students from one school district in Louisiana. Thus, the generalization of the results of this study to other student populations clearly is limited.

\section{Future Research}

The paramount issue in acceptability research is empirically evaluating the acceptability-effectiveness relation. The future development of treatment acceptability and its acceptance into the mainstream of applied behavior analysis and educational treatment design depends 
upon resolving this issue. If applied research demonstrates that pretreatment acceptability ratings of treatments correlate highly with the effectiveness of a given treatment, then the use of social validation measures such as the children's Intervention Rating Profile, the Intervention Rating Profile, and the Behavior Intervention Rating scale can lead to improved service delivery. However, if the acceptability-effectiveness relation cannot be established, then the use of social validation measures becomes primarily a legal consideration or ethical nicety.

In the present study, as in most of the treatment acceptability studies to date, all of the treatment methods rated by students were mildly to moderately acceptable. In future studies, the treatments that students rate should also include treatments that are mildly to moderately unacceptable. There are, however, ethical problems in actually implementing such treatment with individuals. Having a full range of acceptability ratings would allow for more robust evaluations of the acceptabllity-effectiveness relation. 
Although some similarities exist between the procedures used in the present study and the Shapiro and Goldberg studies, direct comparisons cannot be made because of differences in the basic designs of the studies. In the present study, students only received one type of group contingency and the study was conducted in an experimental classroom analogous to the types of academic conditions students receive in a resource room. The studies by Shapiro and Goldberg (1986, 1987) were conducted as modifications to the regular classroom curriculum using an alternating treatments design. Future group contingency studies should be designed to more directly compare the types of settings the treatments occur in and the types of group contingencies used.

The complete group contingency paradigm contains the interdependent, dependent, and independent contingencies. In the present study, because of the limited sample size and the desire to include a control subgroup, all of the forms of group contingencies were not used as treatment methods. Future research should encorporate all three group contingencies and a no incentive 
control group.

Although informative, the use of a reversal

phase in the present study contributed to high levels of student attrition. Perhaps a better use of the two-weeks that was spent in reversal, would be to extend the treatment phase. Future studies should carefully weigh the advantages of extended treatment time to the benefits of reversing the treatment conditions.

The small sizes of the treatment subgroups in the present study may have affected the results of several of the group analyses. Future studies planning group analyses should carefully consider the student sample sizes and decrease the number of independent variables, if necessary, to insure that larger cell sizes exist.

Finally, the treatment acceptability ratings of teachers, parents, and students needs to be assessed in naturalistic settings. Thus far, the treatment acceptability research comparing the acceptability ratings of teachers, parents, and students has been analogue. 
Implications of This study for Applifed Regearch

As a result of this study, in conjunction with shapiro and Goldberg (1987), we can now support some previous notions about the nature of treatment acceptability measurements. First, the acceptability ratings of individual students seem to show considerable change over time. These changes occur as actual exposures to treatments increase. When considering the acceptability ratings of groups of students, in the absence of naturalistic exposures to the treatments, acceptability ratings do not significantly change over 6 to 7 week periods. However, when students actually experienced one of the treatment methods, their acceptability ratings show statistically significant changes over time. Thus, experience with some form of a treatment method seems to provide rather young students meaningful information which they use when evaluating the acceptability of treatments. Consequently, psychologist wishing to involve students in the selection of treatment should be aware that inexperienced students may evaluate the treatments quite differently than experienced students. 
Another important implication of the present study is that a number of side effects may occur as a result of treatment. In the present study, side effects were found in treatment integrity, regular classroom spelling performances, and peer-nominated social status. Future researchers should attempt to identify, quantify, and measure as many of these potential side effects as possible. This procedure would aid in the understanding of the results of future treatment studies.

Analogue research methods have aided in the development of the treatment acceptability paradigm to this point. However, in light of the findings of this study and Shapiro and Goldberg (1987), analogue techniques should be used judiciously in treatment acceptability research. Analogue treatment acceptability research has the advantage of allowing consumers to choose between a number of potentially effective treatment methods. The methods the students rate can be so extreme that the naturalistic evaluations of the treatments is impractical and inappropriate for naturalistic evaluation. As the results of this study have indicated, students' acceptability ratings are 
significantly affected by increases in students' knowledge of a treatment method. Thus, the results from analogue treatment acceptability studies may be considerably different from the acceptability measures derived from naturalistic assessment. Conclusions and summary

This study has begun to answer several important questions about the nature of the treatment acceptability paradigm. Based upon the combined results of this study and Shapiro and Goldberg's (1987) recent study, we can conclude that student's treatment acceptability ratings significantly change when the students are exposed to the treatment methods they are rating. On the other hand, if students are not exposed to the treatment methods, their treatment acceptability ratings do not seem to change significantly over a 6 to 7 week period. These conclusions are particularly important to the future development of the treatment acceptability paradigm for at least two reasons. This implies that students' treatment acceptability ratings are not whimsical, fleeting judgments about treatments. Acceptability ratings have some stability over time that can be changed 
as a result of a greater understanding of the treatment methods. These conclusions also imply that the Children's Intervention Rating Profile is a fairly sensitive instrument capable of detecting changes in students' attitudes about treatments over time.

The results of the present study and shapiro and Goldberg's (1987) study have raised some questions about the nature of acceptability changes. Both studies found that when students are involved in a particular treatment, their acceptability ratings of the treatment changes. However, in the present study these changes in acceptability were decrements and in the shapiro and Goldberg (1987) study these changes were increments. Although some speculations have been made to account for the differences in the directionality of these posttreatment acceptability changes, we do not have enough evidence to draw firm conclusions.

The present study failed to provide a definitive answer to the hypothetical acceptability-effectiveness relation. This relation is a critical portion of the acceptability 
paradigm. Answering this question should be of prime importance to treatment acceptability researchers in the future.

This study has also helped to dispell the belief that the use of group contingencies will lead to negative peer pressures. Even when the dependent group contingency was used, overall negative changes in social status were not significant. This study attests to the use of group contingencies and cooperative techniques in classrooms without large concern of negative social side effects.

The attempt this study made to infuse the cooperative learning theory with the group contingency paradigm, was statistically nonsignificant, but yielded some encouraging trends. The cooperative learning model is more comprehensive in scope than the group contingency paradigm, so continued attempts to merge the two approaches is theoretically and pragmatically warranted. 


\section{References}

Allen, V. L., Levin, J. M. (1971). Social support and conformity: The role of independent assessment of reality. Journal of Experimental social Psychology, 2, 48-58.

Allen, D. J., McLaughlin, T. F., Harman, R. (1980). The differential effects of independent and interdependent group-oriented contingencies upon a letter tracing task in a special education token reinforcement program. corrective and social Pgychiatry, 26, 110-115.

Armstrong, B., Johnson, D. W., Balow, B. (1981). Effects of cooperative vs. Individualistic learning experiences on interpersonal attraction between learning-disabled and normal-progress elementary students. Contemporary Educational Psychology,

6. 102-109.

Aronson, E. (1978). The jigsaw classroom.

Beverly Hills, Calif.: Sage. 
Asch, S.E. (1951). Effects of group pressure upon the modification and distortion of judgments. In H. Guetzkow (Ed.), Groups, leadership and men. Pittsburg, PA: Carnegie Press.

Axelrod, S. (1973). Comparisons of individual and group contingencies in two special classes. Behavior Therapy, 4, 83-90. Ballard, M., Corman, L., Gottlieb, J., \& Kaufman, M. (1977). Improving the social status of mainstreamed retarded children. Journal of Educational Psychology, 69, 605-611.

Bandura, A. (1969). Principles of behavior modification. New York: Holt, Rhinehart \& winston.

Barrish, H. H., Saunders, M., Wolf, M. M. (1969). Good behavior game: Effects of individual contingencies for group consequences on disruptive behavior in a classroom. Journal of Applied Behavior Analysis, 2, 119-124.

Brehm, J. W. (1966). A theory of psychological reactance. New York: Academic Press. 
Broughton, S. F. (1983). The lack of vicarious effects with contingent teacher attention for academic performance. Child \& Family Behavior Therapy, 5(1), 25-36.

Chadwick, B. A., Day, R. C. (1971). Systematic reinforcement: Academic performance of underachieving students. Journal of Applied Behavior Analysis, 4, 311-319. Coie, J. D., Dodge, K. A., \& Coppotelli, H. (1982). Dimension and types of social status:

A cross-age perspective. Developmental Psychology, 18, 557-570. Crouch, P. L., Gresham, F. M., \& Wright, W. R. (1985) - Interdependent and independent group contingencies with immediate and delayed reinforcement for controlling classroom behavior. Journal of School Psychology, 23, 177-187. Deci, E. (1971). Effects of externally mediated rewards on intrinsic motivation. Journal of Personality and social Psychology, 18, 105-111. 
Drabman, R., spitalnik, R. Spitalnik, K. (1974) . systematic and disruptive behavior as a function of four types of token reinforcement programs. Journal of Applied Behavior Analysis, 7, 93-101.

Elliott, S. N., Turco, T. L., Gresham, F. M. (in press). Consumers' and clients' pretreatment acceptability ratings of classroom-based group contingencies. Journal of School Psychology.

Elliott, s. N., witt, J. C., Galvin, G., \& Moe, G. (1986) - Acceptability of classroom interventions: Factors that influence teachers' decisions. Professional Psychology: Research and Practice, 14, $1-6$.

Elliott, S. N., witt, J. C., Galvin, G., \& Petersen, J. L. (1984). Acceptability of positive and reductive interventions: Factors that influence teachers' decisions. Journal of School Psychology, 22, 353-360. 
Evans, G. W. \& Oswalt, G. L. (1968) . Acceleration of academic progress through the manipulation of peer influence. Behavior Research and Therapy, 6, 189-196.

Grandy, G. S., Madsen, C. H., \& De Mersseman, L. M. (1973) . The effects of individual and interdependent contingencies on inappropriate classroom behavior. Psychology in the Schools, 10, 488-493.

Greenwood, C. R. Hops, H. (1981) . Group-oriented contingencies and peer behavior change. In P. S. Strain (Ed.), The utilization of classroom peers as behavior change agents. New York: Plenum. Gresham, F. M., Gresham, G. N. (1982). Interdependent, dependent, and independent group contingencies for controlling disruptive behavior. The Journal of Special Education, 16. $101-110$.

Hall, R. V., Lund, D., \& Jackson, D. (1968). Effects of teacher attention on study behavior. Journal of Applied Behavior Analysis, 1, 1-12. 
Haring, N. G., \& Hauck, H. A. (1969). Improved learning conditions in the establishment of reading skills with disabled readers. Exceptional Children, 35(5), 341-352.

Harris, v. w., \& Sherman, J. A. (1973). The use and analysis of the "Good Behavior Game" to reduce disruptive behavior. Journal of Applied Behavior Analysis, 6, 405-417.

Hayes, L. A. (1976). The use of group contingencies for behavioral control. Psychological Bulletin, 83, 628-648. Hopkins, B. L., Schutte, R. C., \& Garton, K. L. (1971). The effects of access to a playroom on the rate and quality of printing and writing of first and second-grade students. Journal of Applied Behavior Analysis, $6(3)$, 425-433.

Johnson, D. W., \& Johnson, R. T. (1975) .

Learning together and alone. Englewood Cliffs, NJ: Prentice-Hall. 
Johnson, D. W., Maruyama, G., Johnson, R., Nelson, D., Skon, L. (1981). Effects of cooperative, competitive, and individualistic goal structures on achievement: A metaanalysis. Psychological Bulletin, 89, 47-62.

Kagan, S. (1985). Dimensions of cooperative classroom structures. In R. Slavin, S. Sharan, s. Kagan, R. Hertz-Lararowitz, C. Webb, \& R. Schmuck (Eds.), Learning to cooperate, cooperating to learn. New York: Plenum Press. Kazdin, A. E. (1980). Acceptability of time out from reinforcement procedures for disruptive child behavior. Behavior Therapy, 11, 329-344. Kottmeyer, w. \& Claus, A. (1976). Basic goals in spelling. New York: McGraw-Hill Book Company. 
Lepper, M., Greene, D. \& Nisbett, R. (1973). Undermining children's interest with extrinsic rewards: A test of the "overjustification hypothesis." Journal of Personality and Social Psychology, 28, 129-137.

Litow, L., Pumroy, D. K. (1975). A brief review of classroom group-oriented contingencies. Journal of Applied Behavior Analysis, $8, \quad 341-347$.

Lovitt, T. C, Guppy, T. E., \& Blettner, J. E. (1969). The use of free-time contingency with fourth graders to increase spelling accuracy. Behaviour Research and Therapy, 2, 151-156. Madden, N. A., \& Slavin, R. E. (1983)'. Cooperative learning and social acceptance of mainstreamed academically handicapped students. Journal of Special Education, $17,171-182$.

Mann, L. (1977). The effects of atimulus queues on queue-joining behavior. Journal of Personality and social Pgychology, 35, $437-442$. 
Marascuilot, L. A. Levin, J. R. (1970).

Appropriate post hoc comparisons for

interaction and nested hypothesis

in analysis of variance designs:

The elimination of Type IV errors.

American Educational Research

Journal, 7, 397-421.

McCarty, T., Griffin, S., Apolloni, T., \& Shores,

R. E. (1977). Increased peer-teaching with

group-oriented contingenciess for arithmetic

performance in behavior-disordered

adolescents. Journal of Applied Behavior

Analysis, 10, 313 .

McLaughlin, T. F. (1974). A review of applications

of group-contingency procedures in behavior

modification in the regular classroom: some

recommendations for school personnel.

Psychological Reports, 355, 1299-1303.

McLaughlin, T. F. (1981) . The effects of

individual and group contingencies on reading

performance of special education students.

Contemporary Educational Psychology, 6, 76-79. 
McLaughlin, T. F. (1982) - A comparison of

individual and group contingencies on spelling performance with special education students. Child and Family Behavior Therapy, 4, 1-10.

McLaughlin, T. F., \&alaby, J. (1972). Reducing and measuring inappropriate verbalizations in a token classroom. Sournal of Applied Behavior Analysis, 5, 329-333.

Maloney, K. B., \&opkins, B. L. (1973). The modification of sentence structure and its relationship to subjective judgments of creativity in writing. Journal of Applied Behavior Analysis, 6(3), 425-433.

Milgram, S. (1963). Behavorial study of obedience. Journal of Abnormal and Social Psychology, 67, 371-378. Milgram, S., Bickman, L., Berkowitz, L. (1969). Note on the drawing power of crowds of different size. Journal of Personality and Social Psychology, 13, 79-82. Neumann, J. K. (1977). An analysis of group contingency data. Journal of Applied Behavior Analysis, 10, 755-758. 
Packard, R. (1970). The control of "classroom attention": A group contingency for complex behavior. Journal of Applied Behavior Analysis, 3, 13-28.

Pigott, H. E., Fantuzzo, J. W., clement, P. W. (1986). The effects of reciprocal peer tutoring and group contingencies on the academic performance of elementary school children. Journal of Applied Behavior Analysis, 19, 93-98.

Pigott, H. E., Fantuzzo, J. W., \&eggie, D. L. (1984). A student-administered group-oriented contingency intervention: Its efficacy in a regular classroom. Child \& Family Behavior Therapy, 6 , 41-56.

Pigott, H. E., \& Heggie, D. L. (1986). Interpreting the conflicting results of individual versus group contingencies in classrooms: The targeted behavior as a mediating variable. Child \&amily Behaviof Therapy, 7(4), 1-15. 
Quay, H. C., Werry, J. S., McQueen, M., \& Sprague, R. L. (1966). Remediation of the conduct problem child in the special class setting. Exceptional children, 32, 509-515. Sears, D. O., Freedman, J. L., Peplau, I. A. (1985). Social Psychology (5th ed.). New Jersey: Prentice-Hall.

Shapiro, E. S., Albright, T. S., Ager, C. L. (in press). Group versus individual contingencies in modifying two disruptive adolescent's behavior. Professional school Psychology. Shapiro, E. S., \& Goldberg, R. (1986). A comparison of group contingencies in increasing spelling performances among sixth grade students. School Psychology Review, 15, 546-557.

Shapiro, E. S., \& Goldberg, R. (1987, May). symposium on treatment acceptability. Presented at the annual convention of Applied Behavior Analysis, Nashville. Sharan, S., \& Sharan, Y. (1976). Small-aroup teaching. Englewood cliffs, NJ: PrenticeHal1. 
Shores, R. E., Apolloni, T., \& Norman, C. $W$. (1976). Changes in peer verbalizations accompanying individual and group contingencies to modify on-task behavior.

Perceptual and Motor Skills, 43, 1155-1162. Slavin, R. E. (1977). Classroom reward structure: An analytic and practical review. Review of Educational Research, 47 (4), 633-650. Slavin, R. E. (1980). Using student team learning (rev, ed.). Baltimore, MD.: Center for Social organization of Schools, John Hopkins University. Slavin, R. E. (1983). When does cooperative learning Increase student achievement? Psychological Bulletin, 24 (3), 429-445. Slavin, R. E. (1985). An introduction to cooperative learning research. In R. Slavin, S. Sharan, S. Kagan, R. Hertz-Lararowitz, C. Webb, R. Schmuck (Eds.), Learning to cooperate, cooperating to learn. New York: P1enum Press. 
sloggett, B. B. (1971). Use of group activities and team rewards to increase individual classroom productivity. Teaching Exceptional Children, 3, 54-66.

Turco, T. L., \& Elliott, S. N. (1986a) . Assessment of students' acceptability of teacher-initiated interventions for classroom misbehaviors. Journal of school Psychology, 24, 307-313.

Turco, T. L., Elliott, S. N. (1986b). students' acceptability ratings of interventions for classroom misbehaviors: A study of well-behaving and misbehaving youth. Journal of Psychoeducational

Assessment, 4, 281-289.

Turco, T. L., Elliott, s. N., \& Witt, J. C. (1985). Children's involvement in treatment selection: A review of theory and analogue research on treatment acceptability. Monograph on Secondary Behavioral Disorders. Reston, VA: CEC. 
Turco, T. L., witt, J. C., Elliott, S. N. (1985). Factors influencing teachers' acceptability of classroom interventions for deviant student behavior. Konograph on Secondary Behavioral Disorders. Reston, VA: CEC.

Von Brock, M. B., Elliott, S. N. (1986). The influence of treatment effectiveness information on the acceptability of classroom interventions. Manuscript submitted for publication.

Wasik, B. H. (1970). The application of Premack's generalization on reinforcement to the management of classroom behavior. Journal of Experimental Child Psychology, 10, 33-43. Witt, J. C., \& Elliott, S. N. (1983). Assessment in behavioral consultation: The initial interview. School Psychology Review, 12, 42-49. 
Witt, J. C., Elliott, s. N. (1985).

Acceptability of classroom management

strategies. In T. R. Krotochw1ll (Ed.),

Advances in school psychology. (Vol. 4),

(pp. 251-288). Hillsdale, NJ: Lawrence

Erlbaum.

Witt, J. C., Elliott, S. N., \&artens, B. K. (1984). Acceptability of behavioral

interventions used in classrooms: The influence of amount of teacher time, severity of behavior problem, and type

of intervention. Behavioral Disorders, 2, 95-104.

Witt, J. C., \&artens, B. K. (1983). Assessing the acceptability of behavioral interventions. Psychology in the schools, 20, 570-517.

Witt, J. C., Martens, B. K., Elliott, s. N. (1984). Factors affecting teachers' judgments of the acceptability of behavioral interventions: Time involvement, behavior problem severity, and type of intervention. Behavior Therapy, 15, 204-209. 
Witt, J. C., Robbins, J. R. (in press).

Acceptability of reductive interventions

for the control of inappropriate child

behavior. Journal of Abnormal Child

Psychology.

Wodarski, J. S., Hamblin, R. L., Buckholdt, D. R.,

\& Ferritor, D. E. (1973). Individual

consequences vs. different shared consequences

contingent on the performance of

low-achieving group members. Journal of

Applied social Psychology, 3, 276-290.

Wolf, M. M. (1978) . Social validitiy: The case

for subjective measurement or how applied

behavior analysis is finding its heart.

Journal of Applied Behavior Analysis, 11 ,

203-214.

Wolfe, J. A., Fantuzzo, J., \&olter, C. (1984).

student-administered group-oriented

contingencies: A method of combining

group-oriented contingencies and self-directed

behavior to increase academic productivity.

Child \& Family Behavior Therapy, 6(3), 45-60. 


\section{Appendix A}

Word Lists Used During This study

166 
Baseline 1 Week 1. afraid, abroad, cyclone, betray, abrupt, eclipse, ashamed, zebra, hydrant, hyphen, migrate, ashore, gather, blanket, beckon, checkers, cracker, picket, camper, smother Baseline 1 Week 2. spider, climate, erase, spoken, avoid, event, frozen, aware, beware, elect, lizard, satin, granite, madam, menu, legend, timid, quiver, comic, threaten

Baseline 1 Week 3. amaze, fever, select, secure, siren, clover, amuse, unit, arose, faucet, giraffe, talent, canal, modest, credit, shiver, mimic, olive, cavern, heaven

Baseline 1 Week 4. pantry, improve, attract, employ, monster, pilgrim, hamster, orphan, purchase, apply, lobster, orchard, mistress, further, simply, fortress, handsome, artic, necklace, antler

Baseline 2 Week 1. neon, triumph, poet, violet, period, area, diary, theater, ideal, medium, meteor, genius, heroic, stadium, theory, radius, oasis, vacuum, pioneer, diagram 
Baseline 2 Week 2. cabbage, sausage, baggage, village, passage, luggage, image, shortage, voyage, savage, postage, fixture, feature, venture, torture, puncture, gesture, active, captive, native Treatment Week 1. argument, amusement, ornament, settlement, equipment, government, witness, sickness, sadness, wilderness, eagerness, foolishness, entrance, ambulance, attendance, importance, absence, presence, prudence, audience Treatment Week 2. union, onion, opinion, mansion, mission, television, division, motion, section, mention, fraction, notion, fiction, direction, vacation, collection, position, suggestion, election, pollution

Treatment week 3. companion, invisible, expression, remarkable, invention, department, endurance, disgraceful, unkindness, confident, prediction, protection, independence, delicious, descendent, excellent, defenseless, compliment, enjoyable, excitement 
Treatment Week 4. hamburger, chocolate, detective, astronaut, carpenter, prisoner, magazine, satelite, celebrate, desperate, general, telegraph, opposite, messenger, festival, holiday, paragraph, practical, tropical, mosquito

Baseline 2 Week 3. helicopter, arithmetic, thermometer, alligator, manufacture, particular, automobile, librarian, original, temperature, evaporate, emergency, dictionary, geography, necessary, ordinary, scientific, democracy, apologize, territory

Baseline 2. Week 4. I inoleum, accompany, escalator, superior, automatic, certificate, astronomer, temporary, numerator, motorcycle, caterpillar, occasional, violinist, barometer, parenthesis, mathematics, mechanical, patriotic, stationary, elevator 
Appendix $\mathrm{B}$

Treatment Acceptability Probe 
Write your name here:

I want to know how you feel about six ways your teacher can help you to do better in spelling. On each page I have given you, I want you to do the same things. You will first read a short paragraph telling you about what your teacher wants to do in the classroom to help you with spelling. Then you will answer seven short questions about how you feel about what your teacher wants to do. Because I want to know how each of you feels, there are no right or wrong answers to the questions. So please do your own work.

You are going to be asked to answer the questions in a way that might be new to you. Let's look at a couple of examples.

Look at this question:

I agree

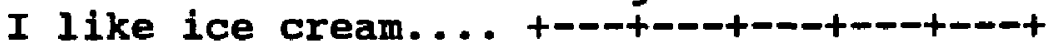

I do not agree

Notice that above the marks at the right are the labels "I agree" and "I do not agree." If you agree with the statement the most that you can, you would circle the + sign to the far left of the scale under where it says "I agree", like this:

I

agree
I do not agree

I like ice cream.... + +-- ++--+---+---+---+

If you do not agree with the statement the most you possibly can (you do not like ice cream), you would circle the + sign under where it says "I do not agree," like this:

I

agree

I like ice cream.... + +-
I do

not

agree

If you agree with the statement just a little bit, you would circle the + sign near the middle like this:

$\mathbf{I}$

agree

I like ice cream.... + +-- +-
I do not agree 
Your teacher is going to use a new way of helping you do better in spelling. You are going to be put in a spelling group with two other students. You are going to study your speling words with the other students in your group. on Friday, every student in your group will take a speliing test. If your group gets an average of 16 of the 20 spelling words correct, everyone in your group will be able to choose a reward.

$\begin{array}{cc}I & I \text { do } \\ \text { agree } & \text { agree }\end{array}$

1. The method used to deal with the spelling problem was fair.......

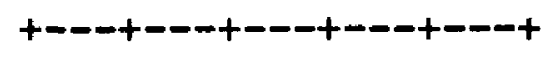

2. This student's teacher was too harsh on him...

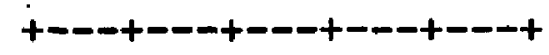

3. The method used to deal with the spelling problem may cause problems with this student's friends......

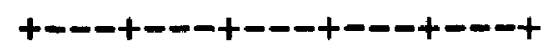

4. There are better ways to handle this student's spelling problem than the one described here..

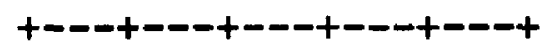

5. The method used by this teacher would be a good one to use with other students.............

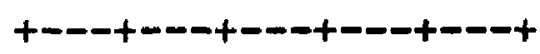

6. I like the method used for this student's spelling problem.......

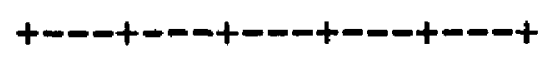

7. I think that the method used for this spelling problem would help this studient do better in school.............. 
Your teacher is going to use a new way of helping you do better in spelling. You are going to be put in a spelling group with two other students. You are going to study your speliing words with the other students in your group. on Friday, every student in your group will take a spelling test. After the spelling test the teacher will select one student from your group. If that student gets 16 of the 20 spelling words correct, everyone in your group will be able to choose a reward.

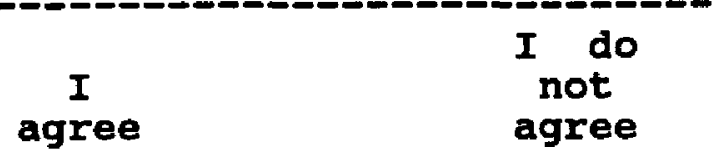

1. The method used to deal with the spelling problem was fair.......

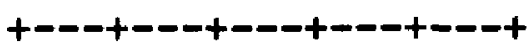

2. This student's teacher was too harsh on him...

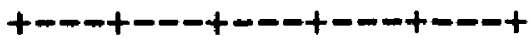

3. The method used to deal with the spelling problem may cause problems with this student's friends......

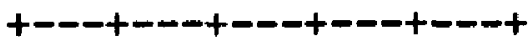

4. There are better ways to handle this student's spelling problem than the one described here..

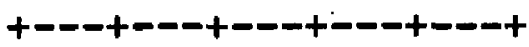

5. The method used by this teacher would be a good one to use with other students.............

6. I like the method used for this student's spelling problem........ $+--++--+--1+--+--+$

7. I think that the method used for this spelling problem would help this student do better in school...............

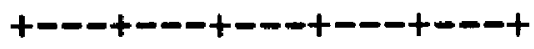


Your teacher is going to use a new way of helping you do better in spelling. You are going to be put in a spelling group with two other students. You are going to study your speliling words with the other students in your group. on Friday, every student in your group will take a spelling test. After the spelling test the teacher will score your test. words correct, everyone in your group will be able to choose a reward.

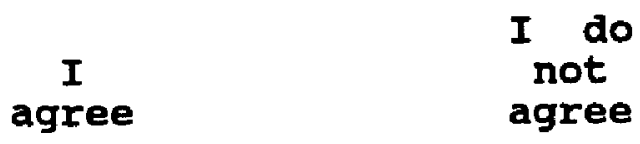

1. The method used to deal with the spelling

problem was fair.......

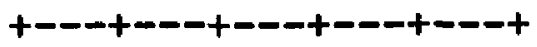

2. This student's teacher was too harsh on him...

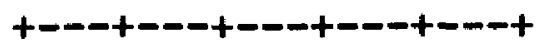

3. The method used to deal with the spelling problem may cause problems with this student's friends......

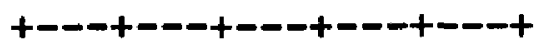

4. There are better ways to handle this student's spelling problem than the one described here..

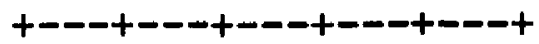

5. The method used by this teacher would be a good one to use with other students..............

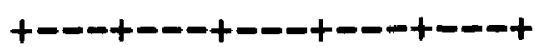

6. I like the method used for this student' $s$ spelling problem.......

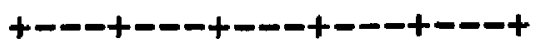

7. I think that the method used for this spelling problem would help this student do better in school............... 
Your teacher is going to use a new way of helping you do better in spelling. You are going to be put in a spelling group with two other students. You are going to study your spelling words by yourself. On Friday, every student in your group will take a spelling test. If your group gets an average of 16 of the 20 spelling words correct, everyone in your group will be able to choose a reward.

$\begin{array}{cc}I & I \text { do } \\ \text { agree } & \text { agree }\end{array}$

1. The method used to deal with the spelling problem was fair.......

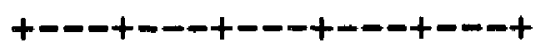

2. This student's teacher was too harsh on him...

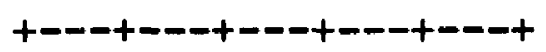

3. The method used to deal with the spelling problem may cause problems with this student's friends......

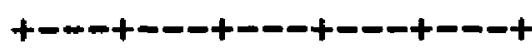

4. There are better ways to handle this student's spelling problem than the one described here..

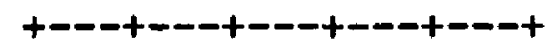

5. The method used by this teacher would be a good one to use with other students.............

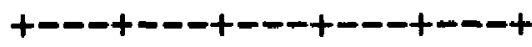

6. I like the method used for this student's spelling problem.......

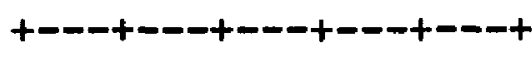

7. I think that the method used for this spelling problem would help this student. do better in school..............

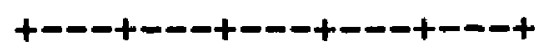


Your teacher is going to use a new way of helping you do better in spelling. You are going to be put in a spelling group with two other students. You are going to study your speliling words by yourself. On Friday, every student in your group will take a spelling test. After the spelling test the teacher will select one student from your group. If that student gets 16 of the 20 spelling words correct, everyone in your group will be able to choose a reward.

$\begin{array}{cc}I & I \text { do } \\ \text { agree } & \text { agree }\end{array}$

1. The method used to deal with the spelling problem was fair......

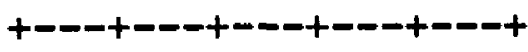

2. This student's teacher was too harsh on him...

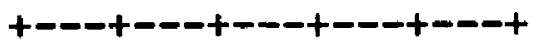

3. The method used to deal with the spelling problem may cause problems with this student's friends.......

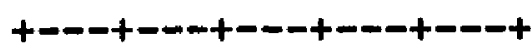

4. There are better ways to handle this student's spelling problem than the one described here..

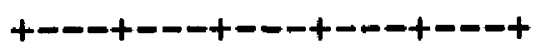

5. The method used by this teacher would be a good one to use with other students............

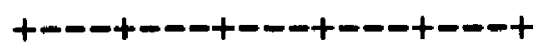

6. I like the method used for this student's spelling problem........

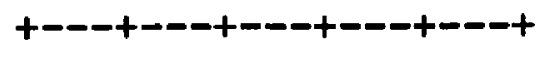

7. I think that the method used for this spelling problem would help this student do better in school.............. 
Your teacher is going to use a new way of helping you do better in spelling. You are going to be put in a spelling group with two other students. You are going to study your speliling words by yourself. On Friday, every student in your group will take a spelling test. After the spelling test the teacher will score your test. words correct, everyone in your group will be able to choose a reward.

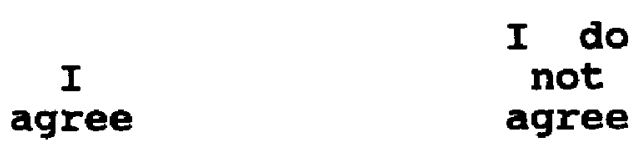

1. The method used to deal with the spelling

problem was fair.......

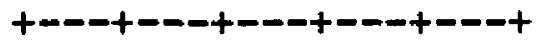

2. This student's teacher was too harsh on him...

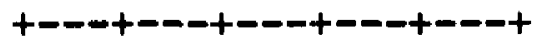

3. The method used to deal with the spelling problem may cause problems with this student's friends......

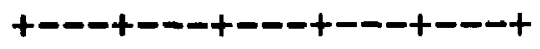

4. There are better ways to handle this student's spelling problem than the one described here..

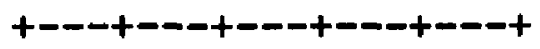

5. The method used by this teacher would be a good one to use with other students.............

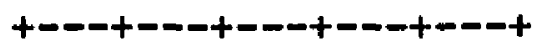

6. I like the method used for this student's spelling problem.......

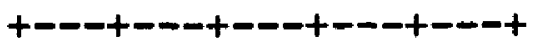

7. I think that the method used for this spelling problem would help this student do better in school............... 
Appendix $\mathrm{C}$

Parent Permission Letter 
Dear Parent or Guardian:

A special spelling program is about to begin at R. J. Vial school. In this program, fifth-grade students will be given about 90 minutes of additional spelling instruction each week for about 8 weeks. The program will take place at R. J. Vial school and participation is voluntary.

If you would like your fifth-grade child to participate in this program, please sign this form and return it to R. J. Vial school.

This program has nothing to do with special education classes, and your child will not be placed in special education as a result of this program. This program is being conducted by Timothy L. Turco, a school psychology intern in st. Charles parish. The program has been approved by $\mathrm{Mr}$. Coy Landry, the assistant superintendent, Dr. M. Anderson, the principal and R. J. Vial school, and your child's teacher.

Thank you.

$$
\text { Yours truly, }
$$

Timothy L. Turco

I give my permission for my fifth-grade child, to participate in the special spelling program being conducted by Mr. Turco at R. J. Vial school. 
Appendix D

Experimental Teacher Scripts 
$\mathbf{I}$

For the next 20 minutes your are going to study your speliing words by yourself. On Friday every student in your group will take a spelling test. If your group gets an average of 16 of 20 spelling words correct, everyone in your group will be able to choose a reward.

II

For the next 10 minutes your are going to study your spelling words by yourself. On Friday every student in your group will take a spelling test. After the spelling test, I will randomly select on student from your group. If that student gets 16 of 20 spelling words correct, everyone in your group will be able to choose a reward.

III

For the next 10 minutes you are going to study your spelling words by yourself. On Friday every student in your group will take a spelling test. After the test we will score your test. 
IV

For the next 10 minutes your are going to study your spelling words with the other students in your group. On Friday every student in your group will take a spelling test. If your group gets an average of 16 of 20 spelling words correct, everyone in your group will be able to choose a reward.

For the next 10 minutes your are going to study your spelling words with the other students in your group. On Friday every student in your group will take a spelling test. After the spelling test, I will randomly select on student from your group. If that student gets 16 of 20 spelling words correct, everyone in your group will be able to choose a reward.

VI

For the next 10 minutes you are going to study your spelling words with the other students in your group. On Friday every student in your group will take a spelling test. After the test we will score your test 


\section{Appendix E \\ Post Hoc Procedures to Prevent}

Type IV Error

183 
Interaction Cell Means Model

$\begin{array}{ccccc} & \text { I1 } & \text { I2 } & \text { I3 } & \begin{array}{r}\text { Row } \\ \text { Means }\end{array} \\ \text { T1 } & \text { A } & \text { B } & \text { C } & \text { D } \\ \text { T2 } & \text { E } & \text { F } & \text { G } & \text { H }\end{array}$

column

means

$\mathbf{J}$

$\mathbf{K}$

$\mathbf{L}$

$\mathbf{M}$
Grand
Mean

2. Each cell mean (A, B, C, E, F, G) must have the effects due to rows, colums, and the grand mean subtracted from it, so all that remains is the effects due to the interaction. As an example, we will focus on cell $A$. This same procedure must be repeated for $\operatorname{cells} B, C, E, F$, and $G$.

a. remove the column effects:

$$
\mathbf{J}-\mathbf{M}=\mathbf{P}
$$

b. remove the row effects:

$$
\mathbf{D}-\mathbf{M}=\mathbf{Q}
$$

c. remove the grand mean effects:

$$
\mathbf{A}-\mathbf{M}=\mathbf{R}
$$

d. compute the effects due to the interaction:

$$
a=(A)-(P)-(Q)-(R)
$$


3. Repeating this procedure will create an interaction table containing only the effects due to the interaction.

I1 I2 I3

$\begin{array}{llll}\text { T1 } & \mathbf{a} & \mathbf{b} & \mathbf{c} \\ \mathbf{T 2} & \mathbf{d} & \mathbf{e} & \mathbf{f}\end{array}$

4. Now we will illustrate the actual procedure used during this study to conduct the post hoc analysis of the significant Time $X$ Incentive structure interaction.

a. here are the cell means:

Incentive

1

23

\begin{tabular}{llll|l} 
Time 1 & 37.33 & 30.72 & 32.19 & 33.33 \\
Time 2 & 29.11 & 27.52 & 25.09 & 27.24 \\
\cline { 2 - 3 } & 33.22 & 29.12 & 28.64 & 30.33
\end{tabular}

b. here is the derived interaction table:

\begin{tabular}{|c|c|c|}
\hline $\begin{array}{l}\text { Time } 1 \\
\text { Time } 2\end{array}$ & $\begin{array}{c}1 \\
1.11 \\
-1.02\end{array}$ & $\begin{array}{r}2 \\
-1.40 \\
1.09\end{array}$ \\
\hline
\end{tabular}


5. The next step is to derive the critical interaction value (CIV) needed to tell. when a significant interaction exists.

$$
\begin{aligned}
& \text { a. }(\text { CIV })= \pm S(S E) \\
& \text { b. } \begin{array}{l}
2 \\
S
\end{array}=(I-1)(T-1) F \\
& (\mathrm{I}-1)(\mathrm{T}-1), \mathrm{IT}(\mathrm{N}-1) \\
& \text { (1-alpha) } \\
& =2(1) F_{6,462}(.95) \\
& =2(2.12)(.95) \\
& =4.028 \\
& \text { c. } \mathbf{S E}^{2}=\frac{(I-1)(T-1)}{I T} \quad \mathrm{MS \text {errorwithin }} \\
& =\frac{2(1)}{3(2)} \frac{81.48}{78} \\
& =.333(1.04) \\
& =.348 \\
& \text { d. } \operatorname{CIV}= \pm \text { square root of }((4.028)(.348)) \\
& = \pm 1.18
\end{aligned}
$$

6. Every cell in the derived interaction table that exceeds \pm 1.18 is a significant interaction.

7. Only the interaction between Incentive 2 and Time 1 are significant post hoc interactions. 
TIMOTHY LAWRENCE TURCO

PERSONAL DATA

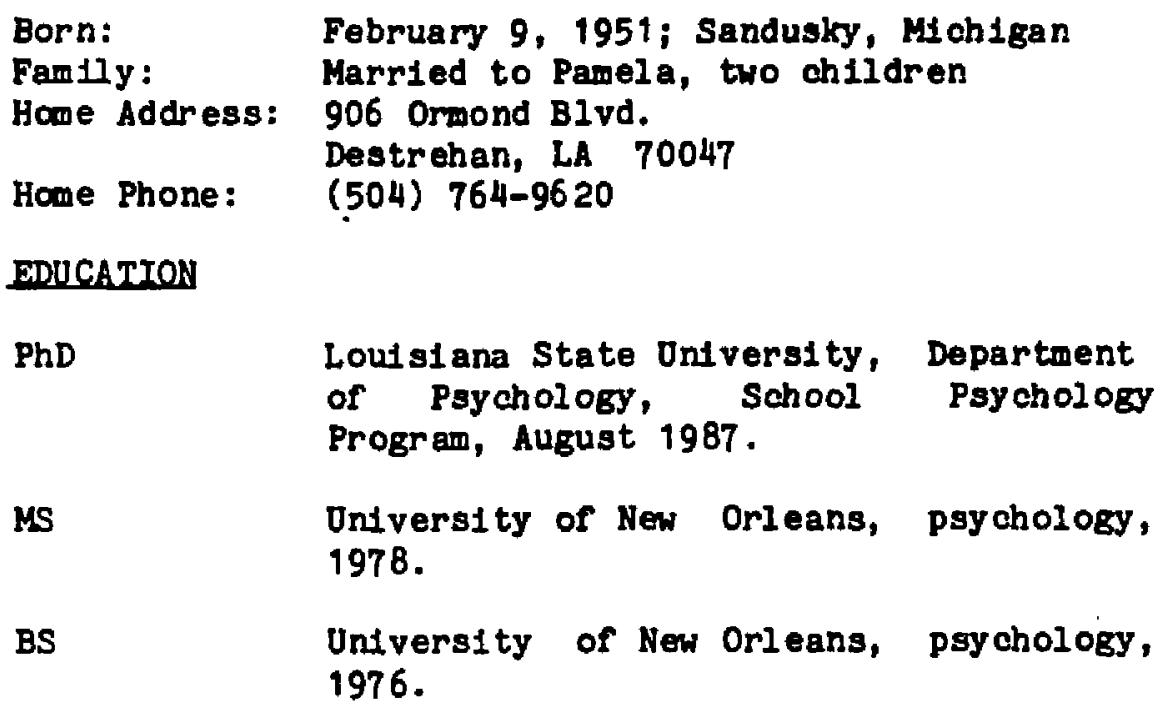

PROEESSTONAL EXPERTENCE

$1986-1987$

1985

1985
SCHOOL PSYCHOLOCIST, St. Charles Parlsh Public Schools, P. O. Box 46, Luling, LA 70070. As a school psychologist, my duties included consultations with teachers, parents, and administrators, and evalua tions of students.

EDITORIAL ASSISTANT, School Psychology Review.

SCHOC PSYCHOLOGIST, Orleans Parish Public Schools, Department of Support and Appraisal, 703 Carondelet Street, New Orleans, LA 70130. Wy duties were 1dentioal to the duties I m performing in st. Charles Partsh. 
$1982-1983$

$1980-1982$

$1978-1980$

1978
SCHOC PSYCHOLOGIST, St. John the Baptist Parish Public Schools, P. o. Drawer AL, Reserve, LA. My duties were 1dentical to the duties I performed in Orleans Parlsh Public Schools.

SCHOC PSYCHOLOGIST, St Charles Parish Public Sohools, P. O. Box 46, Luling, LA 70070. Hy duties were Identical to the duties isted under Orleans Parish schools. I was additionaliy responsible for conducting group and individual therapy and parent training sessions. I co-1mplemented a program of curriculum-based assessment to help deal with students academic problems within the classroom.

EDUCATIONAL PSYCHOLOGIST, OnIversity of New Orleans Special Education Research Evaluation Center, 6601 Franklin Avenue, New Orleans, LA 70122. In accordance with Louisiana Bulletin 1508, the regulations of Act 754, and $P$. L. 94-142, I conducted Individual and group evaluations of students in Orleans Parlsh, Jefferson Parish, and St. Bernard Parlsh.

PSYCHOMETRIST/THERAPIST, POntchartrain Mental Health Center, 4116 old Gentilly Hwy., New Orleans, LA. Ky duties included: administering, Interpreting, and reporting the results of projective and normative referenced psychological tests. The written and oral reports I made with social workers, psychologists, and psychiatrists were used to diagnose patients and to formulate plans for therapy. I was also responsible for conducting both group and Individual therapies with out-patient children and adolescents. 


$$
\begin{aligned}
& \text { PSYCHOLOGICAL EVALOATOR, Southeastern } \\
& \text { Louisiana State Hospital, } \\
& \text { Mandeville, LA. Hy duties included } \\
& \text { the administration, scoring and } \\
& \text { interpretation of the group and } \\
& \text { individual psychological tests. In } \\
& \text { addition, I conducted group and } \\
& \text { Individual therapy sessions in } \\
& \text { behavior modirication, relaxation, } \\
& \text { and transactional analysis to the } \\
& \text { in- and out-patient population. }
\end{aligned}
$$

1976

$$
\begin{aligned}
& \text { RESEARCH ASSISTANT, Rresge Hearing } \\
& \text { Research Laboratory of the South, } \\
& 1100 \text { Florida Avenue, New Orleans, } \\
& \text { LA. My duties included: computer } \\
& \text { programming in machine language, } \\
& \text { FORTRAN, BASIC, and ALGOL to run } \\
& \text { statistical analysis of data and to } \\
& \text { graphically display results. }
\end{aligned}
$$

\section{THESIS \& DISSERTATION}

Turco, T. L. (1978). Heart rate conditioning in young infants using a yisual condstional stimulus. Master's thesis, Untrersity of New Orleans.

Master's thesis abstract was published in the February, 1980 1ssue of the Journal of Psychophysiology.

REFEREED JOURNALS

Elliott, S. N., Argulewioz, E. N., \& Turco, T. L. (1986) Predictive Validity of the Scales for Rating the Behavioral Characteristics of Superior students for Gifted students from Three Sociocultural Groups. Journal of Experimental Education, 55(1), 27-32.

Elliott, S. N., Turco, T. L., Gresham, F. H. (in press) Consumers' and clients! pretreatment acceptability ratings of classrocm-based coup contingencies. Journal of School Psychology.

Turco, T. L. Elllott, S. N. (1986). Assessment of students' acceptability of teacherinitiated Interventions for olassroom misbehaviors. Journal of School Paycholegy, 24, 277-283. 
Turco, T. L. Elliott, S, N. (1986). Students' acceptability ratings of interventions for classrocm misbehaviors: A developmental study of well-behaving and misbehaving youth. Journel of Psychoeducational Assessment.

Turco, T. L., \& Stamps, L. E. (1980). Heart rate conditioning in young infants using a visual conditional stimulus. Journal of Expertmental Child Psychology, 29, 117-125.

\section{BOOK CHAPTERS AND MONOGRAPHS}

Turco, T. L., Elliott, S. N., \& Witt, J. C. (1985). Children's invol vement in treatment selection: A review of theory and analog research on treatwent acceptability. Mongraph en Secondary Behav10ral Disorders. Reston, VA: CEC.

Turco, T. L., Witt, J. C., \&Elliott, S. N. (1985) Factors influencing teachers' acceptability of classrocm interventions for deviant student behavior. Monograph of Secondary Behavioral D1sorders. Reston, VA: CEC.

INVITED REVIEWS AND NONREFEREED JOURNALS

Turco, T. L. (1982). The progress of the Gessell program in St. Charles Parish. Loulsiana School Psychologtcal Association Newsletter.

Turco, T. L. E Elliott, S. N. (In press). Soclal Acceptability. In C. R. Reynolds \& L. Mann (Eds.), Encyclopedia of Spectal Education: $A$ reference for the Education of the Handicapped and other Exceptional Children and Youth. New York: John Wiley \& Sons.

Turco, T. L. \& Elliott, S. N. (in press). Soclal Validation. In C. R. Reynolds \& L. Mann (Eds.), Encyclopedia of Spectal Education: A reference for the Education of the Handicapized and Othor Exceptional Children and Youth. New York: John W1ley sons.

Turco, T. L. Von Brock, M. B. (1985). School Paychology Review: Cumulative indexes 19781985. School Paychology Revies, 14(4), 531555. 


\section{PAPER PRESENTATIONS}

Elliott, S. N. \& Turco, T. L. (1985, February). The use of treatment acceotab121ty techntoues With teachers and children in the school setting. Presented at the Educational and Special Educational Conference, Baton Rouge, Loulsiana.

Elliott, S. N. Turco, T. L. (1984, October). Acceptability of interyentions: Deyelopmental and methodological findings yith normal students. Presented at the conference of Programing for the Developwental Needs of Adolescents with Behavior Disorders II, Pensacola, Florida.

Elliott, S. N., Turco, T. L. (1986, August). Group contingencles and cooperative learning strategies for improving academic performance. Presented as pert of a symposium entitled "Influences on School Learning" at the Annual Convention of the American Psychological Association, Washington, D.C.

Elliott, S. N., Turco, T. L., Gresham, F. M. (1985, August). Group Contingenctes at school: Psycholosists' and ohlldren's treatment acceptabllity ratings. Presented at the Annual Convention of the American Psychological Association, Los Angeles.

Elllott, S. N., Turco, T. L., Evans, S. E., Gresham, F. H. (1984, Nowember). Group contingency Interventions: Children's acceptability ratings. Presented at the annual convention of the Association for the Advancement of Behavior Therapy, Philadephia.

Elliott, S. N., Turco, T. L., Von Brock, M. B. (1986, April). Acceptability of classrocm Interventions: cenceptual issues, research. and practice. Presented at the annual meeting of the National Association of School Psychologists, Orlando, Florida.

Elliott, S. N., Turco, T. L., \& Witt, J. C. (1984, August). Children's acoeptabilfty of classroom interyentions. Presented at the annual convention of the American Paychological Association, Toronto. 
Shaplro, E., Jensen, W., Brown, K., \& Turco, T. L. (1987, May). Symposium on Ireatment Acceptability. Presented at the annual convention of Applied Behavior Analysis, Nashville.

Turco, T. L. (1981), SOMPA ELP's ys SETP's in LD ch1ldren in the Mes orleans area. Presented at the annual meeting of the Louisiana School Psychological Association, New Orleans.

Turco, T. L. (1983, November). Competency based certification of school paychologists. Presented at the annual meeting of the Louisiana School Psychological Association, Jefferson.

Turco, T. L., Elliott, S. N. (1985, Apr11). The effects of students' sex and behayiors on acceptability ratings. Presented at the Annual Convention of the National Association of School Psychologists, Las Vegas.

Turco, T. L., Elliott, S. N., \& Von Brock, M. (1984, October). Children's acceptability ratings of interventions: A discussion of curcent research. Presented at the annual meeting of the Loulsiana School Psychological Association, Kenner, Louisiana.

Turco, T. L., Elliott, s. N., Witt, J. C., \& Galvin, G. A. (1984, Apr 11). Acceptabllity of interventions in third-, fifth-, seventh-. and ninth-grade children. Presented at the annual meeting of the National Association of School Psychologists, Philadelphia.

Turco, T. L. Martens, B. R. (1986, March). Student. teacher, and parent ratings of gcceptability, offectlyeness, and ease of use of elassroom interventions. Presented at the annual meeting of the Southeastern Psychological Association, Orlando, Florida.

Turco, T. L. \&artens, B. R. (1986, April). Studente teacher. and parent ratings of acceptab111ty, effectiveness, and ease of use. Presented at the annual meeting of the National Association of School Psychologists, Hollywood, Florida. 
Turco, T. L. , Miller, J., Shell, D. E. (1982). Curciculum-based assessment program in st. Charles Pactsh. Presented at the Educational and Special Educational Conference, Baton Rouge, Loui siana.

Turco, T. L. Stamps, L. E. (1978). Heart rate conditioning in young infants using a risual conditional stimulus. Presented at the annual meeting of the society for Psyahophystoal Research, Madison, Hisconstn.

Turco, T. L. \& Welsh, J. S. (1987). IBH-PC computer-based case tracking system. Presented at the Seventh Annual Super Conference on Special Educetion, Lafayette, Loul siana.

Welsh, J. S., Mahe, K., Rush, R., Carpenter, V., \& Turco, T. L. (1987). Suicide preyention and reactionary procedures in the school setting: A symposium. Presented at the Seventh Annual Super Conference on Spectal Education, Lafayette, Loulsiana.

Wel sh, J. S., Turco, T. L., Mahe, R., Falrchild, T. (1987). The prevention and treatment of suiclde in academio settings. Presented at the annual meeting of the National Association of School Psychologists, New Orleans, Louisiana.

\section{PROEESSIONAL AFFILIATIONS}

Applied Behavior Analysis, affillate member

American Psychological Association, associate member, membersh1p in progress

Louisiana School Psychological Association

National Association of School Psychologists, membership in progress

\section{CERTIFICATION}

Sahool Psychologist (Masters Degree, plus 30 graduate hours), Louisiana Department of Education.

\section{SCHOLARSHIP}

W. L. Bergeron Scholarship, presented by the Louisiana School Psychological Assoctation, 1985. 
REFERNNCES

Dr. Stephen N. El11ott, Department of Paychology, Louisiana state University, Baton Rouge, LA 70803-5501, (504) 388-8745.

Dr. Frank M. Greshan, Director; School Psychology Program, Department of Psychology, Loulsiana State University, Baton Rouge, LA 708035501, (504) 388-8745.

Dr. Gary Ross-Reynolds, Department of Paychology, Nichols state University, ThIbodeaux, LA.

Dr. Joseph c. Witt, Department of Psychology, Loulsiana State University, Baton Rouge, LA $70803-5501,(504) 388-8745$.

Karen Mahe', Director, Pupll Appraisal Services, St. Charles Partsh Public Schools, P. O. Box 46, Luling, LA 70070, (504) 785-6289. 
DOCTORAL EXAMINATION AND DISSERTATION REPORT

Candidate: Timothy L. Turco

Major Field: Psychology

Title of Dissertation: Acceptability and Effectiveness of Croup Contingencies for Improving Spelling Achievement

Approved:

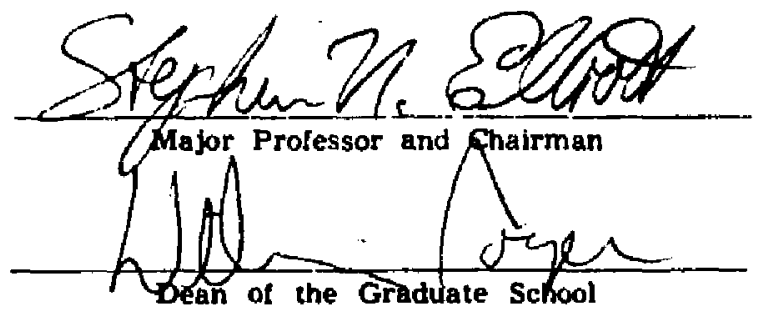

EXAMINING COMMITTEE:

Mary h. Kelley

$\frac{\text { Trances Ph Reck }}{\text { Frank m. Shechem }}$

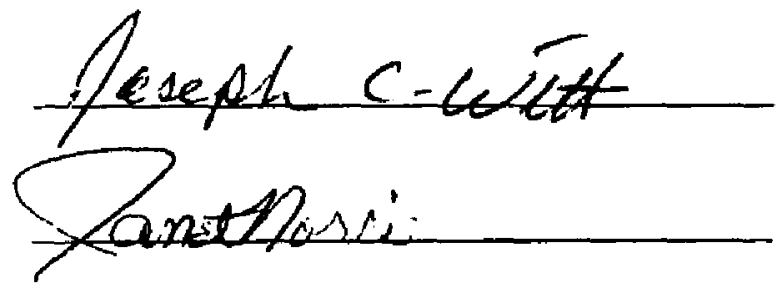

Date of Examination:

fly 3,1987 